Marcelo Mazotti

\title{
JURISDIÇÃO CONSTITUCIONAL E ATIVISMO JUDICIÁRIO: análise comparativa entre a atuação do Supremo Tribunal Federal brasileiro e da Suprema Corte estadunidense
}

\author{
Dissertação de mestrado
}

Orientadora: Profa. Associada Monica Herman Salem Caggiano

Universidade de São Paulo (USP)

Faculdade de Direito do Largo de São Francisco

São Paulo 
Marcelo Mazotti

\section{JURISDIÇÃO CONSTITUCIONAL E ATIVISMO JUDICIÁRIO:}

análise comparativa entre a atuação do Supremo Tribunal Federal brasileiro e da Suprema Corte estadunidense

Dissertação apresentada à Faculdade de Direito do Largo de São Francisco da Universidade de São Paulo (USP) como requisito para a obtenção do título de Mestre em Direito do Estado.

Orientadora: Profa. Associada Monica Herman Salem Caggiano 
Marcelo Mazotti

\section{JURISDIÇÃO CONSTITUCIONAL E ATIVISMO JUDICIÁRIO:}

análise comparativa entre a atuação do Supremo Tribunal Federal brasileiro e da Suprema Corte estadunidense

Dissertação apresentada à Faculdade de Direito do Largo de São Francisco da Universidade de São Paulo (USP) como requisito para a obtenção do título de Mestre.

Departamento de Direito do Estado.

Data de aprovação:

Banca Examinadora:

Prof.(a) Dr.(a)

Instituição:

Assinatura:

Prof.(a) Dr.(a)

Instituição:

Assinatura:

Prof. (a) Dr.(a)

Instituição:

Assinatura: 
DEDICATÓRIA

Dedico esta dissertação àquele e àquelas que já não estão mais do meu lado, mas cujos espíritos foram lição de fortaleza e o amor sinônimo de sustentação. Minhas eternas lembranças. 


\section{AGRADECIMENTOS}

Gostaria de prestar simples e sinceros agradecimentos:

Aos meus pais, José e Cinira, pelo incentivo incondicional a toda uma vida dedicada aos estudos e ao desenvolvimento do espírito por meio das virtudes intelectuais e morais;

À minha nobre e distinta orientadora Monica Herman Salem Caggiano, pelos elevados e eruditos ensinamentos que me guiaram na elaboração deste trabalho,

À professora Fernanda Dias Menezes de Almeida e ao professor Roger Stiefelmann Leal pelas valiosas contribuições na fase de qualificação;

Aos meus amigos, que me apoiaram e estiveram ao meu lado nos momentos mais penosos e desgastantes;

Aos meus ilustres e dedicados colegas de pós-graduação, Alexandre Sanson e Tatiana Penharrubia Fagundes, pelo auxílio concedido e por compartilhar estes anos de amadurecimento intelectual e profissional;

Aos amigos e sócios da FOZ Advogados, que apoiaram minha dedicação aos estudos e compreenderam as ausências necessárias; 


\section{RESUMO}

O ativismo judicial é um fenômeno complexo estudado no Brasil e nos Estados Unidos, geralmente designado como a interferência dos Tribunais nas políticas públicas. Este fenômeno, aparentemente se contradiz com a separação dos poderes e a vontade legislativa democrática expressa em suas Constituições e leis.

A presente dissertação visa comparar como o ativismo judicial se manifesta no Supremo Tribunal Federal brasileiro e na Suprema Corte estadunidense, avaliando suas diferenças e semelhanças.

O poder de controle de constitucionalidade, realizado sobre cláusulas constitucionais abertas, permitiu que ambas as Cortes proferissem decisões de natureza política em inúmeras oportunidades, sendo difícil (ou até mesmo impossível) asseverar se elas se distanciaram da correta interpretação da Constituição, haja vista seus preceitos flexíveis e abstratos.

Os presentes juízes da Suprema Corte têm atuado com autocontenção nas últimas décadas, diminuindo os impulsos ativistas atribuídos às Cortes de Warren e Burger. Ao contrário do Brasil, onde a Constituição de 1988 e as leis recentes aumentaram significativamente o poder do Supremo Tribunal Federal, e seus membros tem utilizado-os sem hesitação.

Palavras-chave: Ativismo judicial. Jurisdição constitucional. Supremo Tribunal Federal. Suprema Corte. Separação de poderes. Controle de constitucionalidade. Democracia e Poder Judiciário. 


\begin{abstract}
Judicial activism is a complex phenomenon studied both in Brazil and in the United States of America, which usually means court's interference in public policies. Such phenomenon apparently contradicts to the separation of powers and the democratic legislative will set forth by the Brazilian and American Constitutions and statutes.

This dissertation compares how the judicial activism manifests itself in the Brazilian Supreme Federal Tribunal and in the American Supreme Court, examining its differences and similarities.

Judicial review based on constitutional open clauses allowed such Courts to make polemic decisions and of political nature in many cases. However it is difficult (rather impossible) to affirm whether such decisions depart from the correct interpretation of both Constitutions due to their flexible and abstract norms.

The current Supreme Court's justices have acted with self-restrained in the late decades, easing the activists impulses accredit to the Warren and Burger's Courts. In contrast the 1988 brazilian Constitution and its subsequent statutes increased the powers of the Supreme Federal Tribunal and its members are exercising them with no hesitation.
\end{abstract}

Keywords: Judicial Activism. Constitutional jurisdiction. Supreme Federal Tribunal. Supreme Court. Separation of Powers. Judicial Review. Democracy and Judicial Power. 


\section{LISTA DE SIGLAS E ABREVIATURAS}

ABA - American Bar Association

ADC - Ação Declaratória de Constitucionalidade

ADI - Ação Direta de Constitucionalidade

ADPF - Ação de Descumprimento de Preceito Fundamental

art. - artigo

CF - Constituição Federal

CPC - Código de Processo Civil

EC - Emenda Constitucional

EUA - Estados Unidos da América

IF - Intervenção Federal

MI - Mandado de Injunção

MS - Mandado de Segurança

NAACP - National Association for the Advancement of Colored People

RISF - Regimento Interno do Senado Federal

RISTF - Regimento Interno do Supremo Tribunal Federal

STF - Supremo Tribunal Federal

US Code-United States Code 


\section{SUMÁRIO}

INTRODUÇÃO. 10

\section{CAPÍtUlO 1. PARÂMETROS METOdOLÓGICOS E OS CONCEITOS DE JURISDIÇÃO CONSTITUCIONAL E ATIVISMO JUDICIÁRIO}

1.1 Delineamentos conceituais. . .13

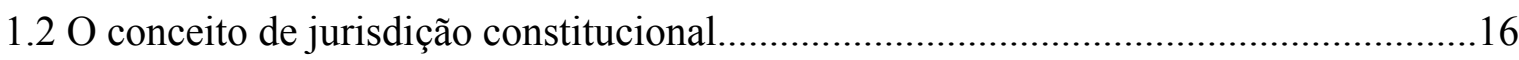

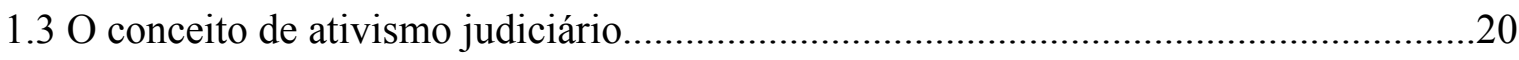

1.3.1 Ativismo como imposição da vontade do juiz em detrimento da lei..........................22

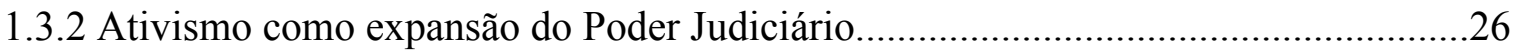

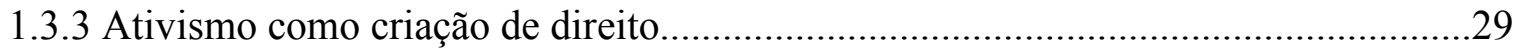

1.3.4 Ativismo como realização de políticas públicas.........................................................30

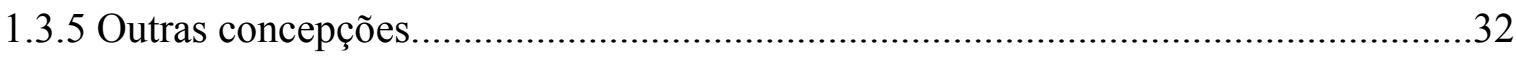

1.3.6 A concepção adotada de ativismo judiciário............................................................33

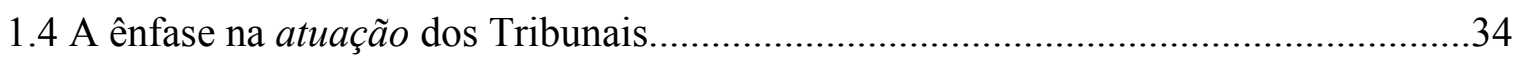

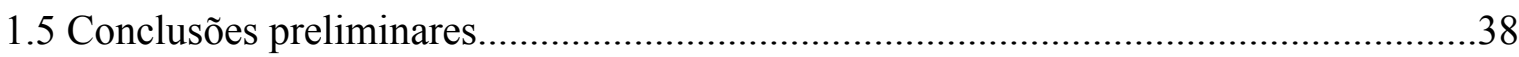

CAPÍTULO 2. ANÁliSE COMPARATIVA ENTRE O SUPREMO TRIBUNAL FEDERAL BRASILEIRO E A SUPREMA CORTE ESTADUNIDENSE

2.1 A origem histórica dos órgãos judiciários supremos do Brasil e dos Estados Unidos da América. 39

2.2 A competência do Supremo Tribunal Federal brasileiro e da Suprema Corte

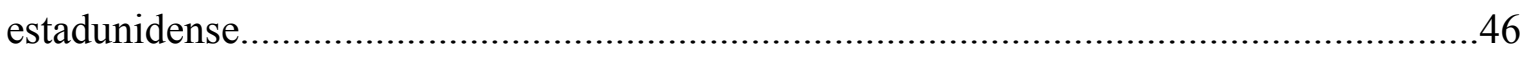

2.2.1 A jurisdição nos EUA: a common law e as justiciability doctrines.............................48

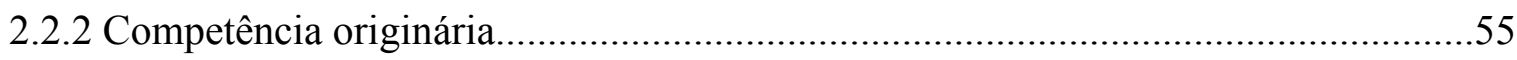

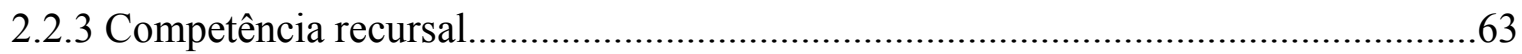

2.2.4 $\mathrm{O}$ controle de constitucionalidade vs. a judicial review............................................71

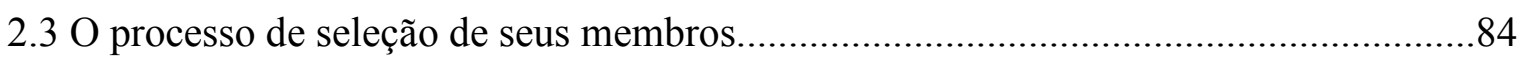

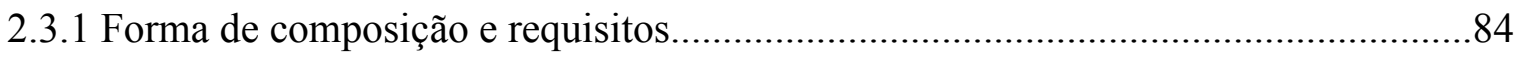

2.3.2 Os atores que participam da escolha: o Poder Executivo, as associações classistas, os grupos de interesse e o Senado Federal............................................................................ 
2.3.3 Quem é escolhido para o órgão judiciário supremo de um país?..............................93

2.3.3.1 A questão da ideologia e do partidarismo.............................................................93

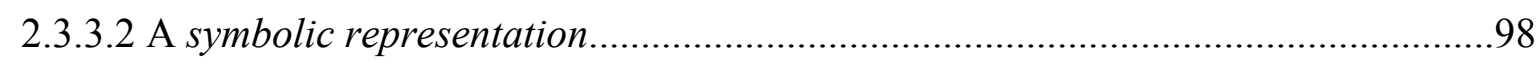

2.3.4 O processo de seleção e a sua legitimidade democrática.........................................99

2.4 Hipóteses de vacância do cargo: morte, aposentadoria, strategic retirement e

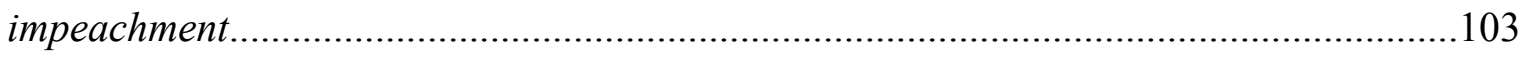

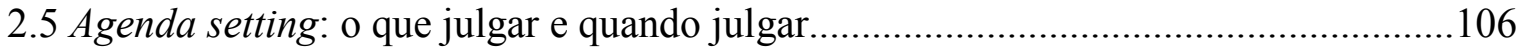

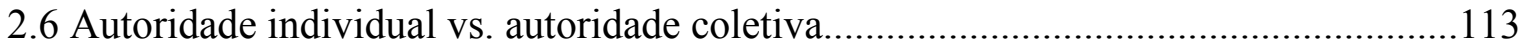

2.7 Implementation process: a autoefetividade das decisões, a reversão legislativa e o

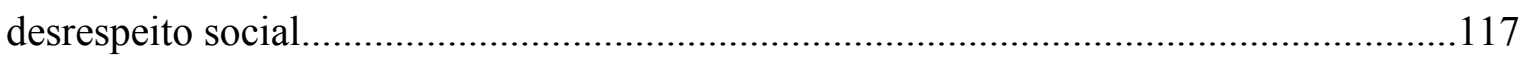

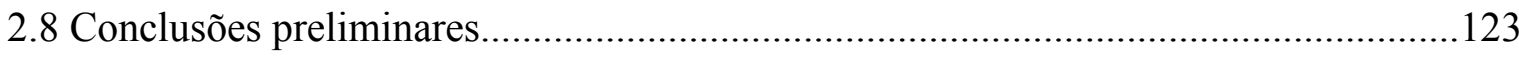

CONCLUSÃO

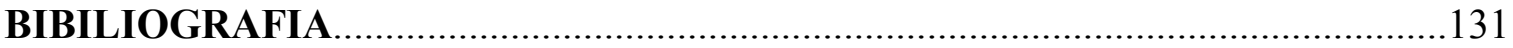




\section{INTRODUÇÃO}

O ativismo judiciário (ou judicial) é certamente um dos temas mais debatidos e controversos no direito constitucional pátrio hodierno. A alegada atuação política dos Tribunais levanta inúmeros questionamentos sob a ótica da separação dos poderes e da legitimidade democrática, principalmente quando os órgãos judiciais criam, modificam ou anulam as políticas públicas aos moldes dos tradicionais decisionmakers.

O modelo dogmático e hermético de separação de poderes não encontra plena ressonância no Texto Constitucional contemporâneo ${ }^{1}$, tornando fluidas e tênues as linhas demarcatórias entre as atribuições de cada um dos Poderes. Além do mais, as inúmeras cláusulas abertas presentes na Carta Magna, consagradoras de princípios, direitos e garantias fundamentais, quando suscitadas no atual modelo de controle de constitucionalidade ${ }^{2}$, possibilitam a livre investigação de conteúdos normativos pelo hermeneuta, favorecendo interpretações mais elásticas e discricionárias, que, em consequência, expandem significativamente os poderes dos Tribunais.

Por fim, o cenário político brasileiro vive uma profunda crise do Poder Legislativo, consumido, em grande parte, pelo bloco monocolor com o Executivo. ${ }^{3}$ Neste contexto, a sociedade e a comunidade jurídica assistem atentas inúmeras decisões do Supremo Tribunal Federal, referentes aos direitos das minorias, o processo eleitoral, o pacto federativo $^{4}$, a concessão judicial de medicamentos ${ }^{5}$, entre outros, que, cada vez mais,

\footnotetext{
${ }^{1}$ FERREIRA FILHO, Manoel Gonçalves. O Poder Judiciário na Constituição de 1988: judicialização da política e politização da justiça. Revista Jurídica da Procuradoria Geral do Município de São Paulo, São Paulo, n.1, p.21-42, 1995.

${ }^{2}$ RAMOS, Elival da Silva. Controle de constitucionalidade no brasil: perspectivas de evolução. São Paulo: Saraiva, 2010

${ }^{3}$ CAGGIANO, Monica Herman Salem. A emergência do Poder Judiciário como contraponto ao bloco monocolor Legislativo/Executivo. In: MORAES, Alexandre (coord.). Os 20 anos da Constituição da República Federativa do Brasil. São Paulo: Atlas, 2009.

${ }^{4}$ ALMEIDA, Fernanda Dias Menezes de. Conflitos entre entes federativos: atuação do Supremo Tribunal Federal no regime da Constituição de 1988. In: MORAES, Alexandre (coord.). Os 20 anos da Constituição da República Federativa do Brasil. São Paulo: Atlas, 2009.

${ }^{5}$ SILVA, Luis Virgilio. Taking from the poor to give to the rich: the individualistic enforcement of social rights. $<$ http://www.enelsyn.gr/papers/w13/Paper\%20by\%20Prof.\%20Virgilio\%20Afonso\%20da\%20Silva.pdf $>$. Acesso em 10.11.2011.
} 
invadem o universo da política, remodelando o sentido de democracia ${ }^{6}$ e de participação cidadã.

Nos Estados Unidos, o fenômeno do ativismo judiciário não é novo, sendo secular a participação da Suprema Corte na vida política do país. A própria criação da judicial review, em Marbury v. Madison (1803), não passa alheia a uma leitura crítica dos interesses partidários que rondaram a decisão, notadamente, a criação de um bunker ideológico no Poder Judiciário pelo Partido Federalista, que visava conter as pretensões do recém-formado Partido Republicano. ${ }^{7}$

Historicamente, decisões como Brown v. Board of Education, Mapp v. Ohio, Roe v. Wade, dentre tantas outras, chamaram a atenção da sociedade e dos Poderes Públicos para a atuação da Suprema Corte, que aumenta ou diminui sua participação como decisionmaker, de acordo com o contexto em voga. ${ }^{8}$

Ao longo das últimas décadas, a doutrina estadunidense formou considerável repertório doutrinário acerca da intricada relação das Cortes com a política, especialmente depois do célebre estudo de Bickel, The least dangerous branch ${ }^{9}$, que escancarou o tema no seio da comunidade jurídica, filosófica e dos cientistas políticos. São inúmeras as obras que tratam do ativismo e promovem um debate plural riquíssimo, destacando-se o originalismo de Scalia ${ }^{10}$, a defesa das minorias contra os monopólios da maioria de Ely ${ }^{11}$, a leitura democrática de Dahl ${ }^{12}$, o locus republicano de Dworkin ${ }^{13}$, a visão equilibrada de Cappelletti ${ }^{14}$, dentre outros.

Para que pudéssemos promover um diálogo com a doutrina estadunidense, compartilhando experiências sem incorrer em importações doutrinárias arbitrárias e superficiais, decidimos analisar, de forma densa e analítica, toda a jurisdição

\footnotetext{
${ }^{6}$ FERREIRA FILHO. A democracia possível. $2^{\text {a }}$ ed. São Paulo: Saraiva, 1974.

${ }^{7}$ ACKERMAN, Bruce. The failure of the founding fathers: Jefferson, Marshall and the rise of presidential democracy. Cambridge: Harvard University Press, 2005.

${ }^{8}$ LEWIS, Frederick P. The context of judicial activism: the endurance of the Warren Court legacy in a conservative age. Sine loco: Rowman \& Littlefield Publishers, 1999.

${ }^{9}$ BICKEL, Alexander M. The least dangerous branch: the Supreme Court at the bar of politics. $2^{\mathrm{a}}$ ed. New Haven: Yale University Press, 1986.

${ }^{10}$ SCALIA, Antonin. Originalism: the lesser evil. The University of Cicinnati Law Review, vol 57, pp. 849-865, 1989.

${ }^{11}$ ELY, John Hart. Democracy and distrust. Cambridge, Massachusetts: Harvard University Press, 1980.

12 DAHL, Robert. Decision making in a democracy: the Supreme Court as a national policy maker. Journal of public Law n. 6, pp 279-295, 1957.

${ }^{13}$ DWORKIN, Ronal. O direito da liberdade: a leitura moral da Constituição norte-americana. Tradução de Marcelo Brandão Cipolla. São Paulo: Martins Fontes, 2006.

${ }^{14}$ CAPPELLETTI, Mauro. Juízes legisladores? Tradução de Carlos Alberto Alvaro de Oliveira. Porto Alegre: Sergio Antonio Fabris Editor, 1999.
} 
constitucional da Suprema Corte e do ativismo judicial por ela praticado, comparando-o com o que atualmente assistimos no Brasil em relação ao Supremo Tribunal Federal. ${ }^{15}$

Deste modo, procedemos em nossos estudos com uma pesquisa inicial das expressões jurisdição constitucional e ativismo judiciário, com o fito de delimitar nossos objetos e compará-los com maior precisão nos dois países.

Posteriormente, realizamos um confronto direto entre o Supremo Tribunal Federal e a Suprema Corte, considerando os temas que estão mais frequentemente associados ao fenômeno do ativismo, tais como: mecanismos de controle de constitucionalidade, forma de nomeação de seus membros, influências partidárias, ideologia judicial, symbolic representation, agenda setting, implementation process, dentre outros.

Ao final, esperamos contribuir para uma reflexão mais profunda da atuação do Supremo Tribunal Federal e da Suprema Corte e, principalmente, adequada ao contexto constitucional, político e social que cada uma delas habita.

\footnotetext{
${ }^{15}$ Para uma análise do ativismo judicial no Brasil, ver RAMOS, Elival da Silva. Ativismo judicial: parâmetros dogmáticos. São Paulo: Saraiva, 2010. Ver também LEAL, Roger Stiefelmann. A judicialização da política. Revista dos Tribunais. Cadernos de Direito Constitucional e Ciência Política, São Paulo, v. 29, p. 230-237, 1999.
} 


\section{CAPÍTULO 1. PARÂMETROS METODOLÓGICOS E OS CONCEITOS DE JURISDIÇÃO CONSTITUCIONAL E ATIVISMO JUDICIÁRIO}

\subsection{Delineamentos conceituais}

O estudo e a adoção de um conceito, antes de tudo, exigem uma pré-compreensão daquilo que é o conceito em si, de modo que ele tenha uma designação própria e não seja confundido com termos próximos, como a ideia, a noção ou a concepção.

Não se visa, com isso, fornecer um "conceito de conceito", visto que se trata de um vocábulo polissêmico de elevada complexidade, podendo variar a partir do enfoque adotado, seja no campo da linguística, da filosofia, da metafísica, da psicologia, entre outros.

O objetivo aqui é puramente metodológico e tópico, isto é, fornecer alguns elementos que possam precisar e delimitar a compreensão de conceito, de modo que ele tenha um sentido manifesto, circunscrito e útil para esta pesquisa acadêmica, afastada qualquer pretensão universalista.

Deste modo, procedemos a uma pesquisa do referido termo em diversos dicionários, sendo que encontramos três elementos que parecem alicerçar a compreensão de conceito em vários campos do conhecimento.

O primeiro deles, e mais intuitivo, está relacionado ao conteúdo, ou seja, todo conceito deve expressar o conteúdo (características ou propriedades) de um objeto. Essa ideia está presente em todas as definições, sendo a mais simples delas:

conceito: 1. Filos. Representação dum objeto pelo pensamento, por meio de suas características gerais [...] 2. Ação de formular uma idéia por meio de palavras; definição, caracterização [...]. ${ }^{16}$ (grifos nossos)

\footnotetext{
${ }^{16}$ FERREIRA, Aurélio Buarque de Holanda. Novo dicionário da língua portuguesa. $1^{\mathrm{a}}$ ed. rev. e aum. Rio de Janeiro: Editora Nova Fronteira, 1975.
} 
O segundo elemento é uma espécie de ponte entre o primeiro e o segundo, isto é, permite que se caminhe entre eles sem obstruções. Poderia ser considerado implícito ao primeiro, mas optamos por deixá-lo manifesto para dar maior clareza ao pensamento.

Esse segundo elemento é a delimitação, que visa precisar e detalhar ao máximo o conteúdo do conceito investigado, de modo que seja possível identificar (terceiro elemento) os objetos que estão abarcados pelo conceito.

Os elementos de delimitação e identificação são fundamentais para a elaboração de um conceito, pois sua ausência prejudica severamente a utilidade de uma pesquisa, na medida em que não permite a identificação dos objetos ou fenômenos que estão sendo trabalhados.

Por exemplo, se asseveramos que o conceito de cachorro é "todo animal mamífero de quatro patas", estamos corretos sob o ponto de vista de suas características, embora outras ainda existam. Todavia, tal conceito não é delimitado o suficiente, pois não permite identificar empiricamente os cães, já que outros animais também têm essas propriedades e não são cachorros (gatos, tigres, etc.).

Outras construções conceituais que se tornam menos consistentes, considerando-se o critério da delimitação, são aquelas amplamente abstratas e notadamente subjetivas. Ex: o canário é uma ave de canto belo. O adjetivo belo tem conotação variável de acordo com cada pessoa; distinto seria falar em canto uniforme, vagaroso, entrecortado, ou outro adjetivo que tenha um sentido mais objetivamente aferível, ainda que não se exija um rigorismo extenuante nessas linhas demarcatórias.

Conteúdo, delimitação e identificação formam um feixe lógico e adequado a uma pesquisa científica séria e metodologicamente orientada de um conceito, pois dá vazão ao estudo de suas características e propriedades, assim como reconhece os objetos materiais ou imateriais por ele abarcados.

Esses elementos estão presentes em grande parte das definições pesquisadas, que trabalham a correlação entre características e classe de objetos nos seguintes termos:

conceito [...] 9 FIL representação mental de um objeto abstrato ou concreto, que se mostra como um instrumento fundamental do pensamento em sua tarefa de identificar, descrever e classificar os diferentes elementos e aspectos da realidade. 10 LING noção abstrata contida nas palavras de uma língua para designar as propriedades e 
características de uma classe de seres, objetos ou entidades abstratas. ${ }^{17}$ (grifos nossos)

conceito [...] Qualquer conceito tem compreensão ou conteúdo e extensão. A primeira já se definiu e é diferente da mera soma das notas do objecto; a segunda consiste nos objectos que o conceito compreende, nos objectos que caem sob o conceito. ${ }^{18}$ (grifos nossos)

conceito: representação geral de uma classe determinada de fenômenos. A própria representação é considerada, a partir de Kant, com um esquematismo reunindo as propriedades essenciais ou típicas dos fenômenos a representar. ${ }^{19}$ (grifos nossos)

De particular interesse a questão da identificação para os fins do nosso trabalho, visto que a maioria (ou todos) os conceitos de ativismo judiciário invocam propriedades de tal forma fluidas que impedem sua constatação empírica.

Assevera-se que o ativismo é um fenômeno presente em decisões judiciais detentoras de diversas características $(x, y$ e $z)$, sem que seja possível por meio delas reconhecer tais decisões. Isto porque, $x, y$ e $z$, ao fim e ao cabo, são propriedades excessivamente vagas e subjetivas que não permitem uma aferição objetiva das decisões que as contêm.

Isso não quer dizer que o ativismo não tenha as características $x, y$ e $z$, apenas que elas não são suficientes para um estudo empírico baseado na identificação da jurisprudência "ativista", sendo este um de nossos objetivos.

Por fim, cumpre salientar que, a despeito do uso rigoroso de conceito que utilizaremos nesta dissertação, outros termos próximos serão empregados de forma mais relaxada e como sinônimos, a saber: concepção e compreensão. Ambas, nesta obra, designam o simples entendimento que alguém possui sobre algo, não querendo com isso significar a conhecimento do objeto em sua integralidade e com parâmetros precisos, podendo ser uma visão parcial, um ponto de vista ou uma noção rudimentar sobre o todo.

Partiremos agora para uma pesquisa dos conceitos de jurisdição constitucional e ativismo judiciário, confrontando-os com os elementos acima descritos (conteúdo,

\footnotetext{
${ }^{17}$ HOUAISS, Antônio [et al]. Dicionário Houaiss da língua portuguesa. Elaborado pelo Instituto Antônio Houaiss de Lexicografia e Banco de Dados da Língua Portuguesa. Rio de Janeiro: Objetiva, 2009.

${ }^{18}$ FERRATER MORA, José. Dicionário de Filosofia. Texto preparado por Eduardo Garcia Belsunce e Ezequiel de Olasco. Tradução por António José Massano e Manuel J. Palmeirim. $4^{\mathrm{a}}$ ed. Lisboa, Publicações Dom Quixote. 1978. p. 67. De acordo com o autor, trata-se de um conceito feito com base em uma lógica de viés fenomenológico.

${ }^{19}$ ARNAUD, André-Jean (direção) [et. al] Dicionário Enciclopédico de Teoria e de Sociologia do Direito. Tradução de Patrice Charles , F. X. Willaume. Rio de Janeiro: Renovar, 1999. p. 126.
} 
delimitação e identificação) e adotando, quando possível, aquele que seja adequado para as finalidades do nosso trabalho.

\section{$1.2 \mathrm{O}$ conceito de jurisdição constitucional}

Não há consenso na doutrina acerca do conceito de jurisdição constitucional, sendo poucos os autores que fornecem uma definição precisa e delimitada sobre a expressão, enquanto a maioria prefere apresentar uma noção vaga ou analisar algumas de suas características.

Além do mais, há um uso indiscriminado dos termos jurisdição e justiça constitucional, não sendo claro se há efetivamente uma distinção entre eles ou se são sinônimos.

De qualquer maneira, nossa pesquisa indicou a existência de duas concepções principais de jurisdição (ou justiça) constitucional, vinculadas às ideias de (i) aplicação e (ii) defesa da Constituição. ${ }^{20}$

A primeira delas tem forte influência da doutrina processualista que associa o conceito de jurisdição ao de resolução de litígios e aplicação da lei ao caso concreto, como pode ser percebido nas seguintes definições abaixo mencionadas:

Conceitua-se a jurisdição, a partir dessas premissas, como função do Estado, destinada à solução imperativa de conflitos e exercida mediante a atuação da vontade do direito em casos concretos. ${ }^{21}$

[...] jurisdição, a qual pode ser definida como a aplicação do direito objetivo a uma pretensão. ${ }^{22}$

Jurisdição. Função indelegável do Estado, realizada por meio do Poder Judiciário, que consiste na resolução dos conflitos de direito a ele submetidos, aplicando a lei ao caso concreto $[\ldots] .{ }^{23}$

\footnotetext{
${ }^{20}$ Neste sentido, Barroso preleciona que "Jurisdição constitucional designa a aplicação da Constituição por juízes e tribunais" (BARROSO, Luis Roberto. O controle de constitucionalidade no direito brasileiro. $4^{\mathrm{a}}$ ed. São Paulo: Saraiva, 2009. p. 3), e Dimitri Dimoulis como uma "forma de procedimentalização judicialiforme que visa a atuação (realização e proteção) da Constituição" (DIMOULIS, DIMITRI (coord.). Dicionário brasileiro de direito constitucional. Instituto Brasileiro de Direito Constitucional. São Paulo: Saraiva, 2007).

${ }^{21}$ DINAMARCO, Cândido Rangel. Instituições de direito processual civil. Vol. I. 6. ed. Rev. e atual. São Paulo: Malheiros, 2009. p. 11.

${ }^{22}$ MARQUES, José Frederico. Instituições de direito processual civil. 1. ed. atual. Campinas: Millennium, 1999. p. 3
} 
Sucintamente, sem preocupação de debate doutrinário, podemos conceituar a jurisdição como o poder, a função e a atividade de fazer atuar o direito, de forma cogente e com a força da imutabilidade, aplicável a uma lide, substituindo-se aos titulares dos interesses em conflito. ${ }^{24}$

$\mathrm{Na}$ doutrina constitucionalista, salientamos a posição do professor José Afonso da Silva, para quem a jurisdição constitucional está ligada à ideia de composição de litígios constitucionais pelo Poder Judiciário, apresentando uma concepção própria sobre tais litígios, afirmando que nem toda competência das Cortes, mesmo do STF, tem essa natureza. $^{25}$

Ocorre que a ótica da jurisdição vinculada à ideia de aplicação é insatisfatória no âmbito do direito constitucional, uma vez que está fortemente arraigada em uma visão de lide de natureza subjetiva (conflito entre partes), própria do direito processual civil e penal, não descrevendo adequadamente a atuação do Supremo Tribunal Federal em sede de conflitos de natureza objetiva (controle abstrato de constitucionalidade), assim como a difícil e intrincada natureza da prerrogativa de edição de súmulas vinculantes.

Não se quer com isso dizer que as definições apresentadas estão equivocadas, mas simplesmente que elas não satisfazem um estudo das competências integrais do Supremo Tribunal Federal brasileiro e da Suprema Corte estadunidense, motivo pelo qual não poderá ser adotada.

O segundo sentido de jurisdição está ligado à ideia de defesa da Constituição, baseada em suas funções históricas de organização estatal e repositório de princípios e direitos, cujo instrumento mais importante de preservação é, sem dúvida nenhuma, o controle de constitucionalidade.

Alexandre de Moraes não adota um conceito de justiça constitucional, mas assevera que ela tem a missão "garantidora do Estado de Direito e dos direitos fundamentais", e fornece os cinco ramos de competência comumente a ela atribuídos:

a) o controle de constitucionalidade das leis e atos normativos do poder público; b) a proteção dos direitos fundamentais; c) controle das regras

\footnotetext{
${ }^{23}$ CRETELLA NETO, José. Dicionário de processo civil. 2. ed. Rio de Janeiro: Forense, 2002. p. 273.

${ }^{24}$ GRECO FILHO, Vicente. Direito processual civil brasileiro. Vol. 2. (atos processuais a recursos e processos nos tribunais). 20 ed rev. e atual. São Paulo: Saraiva, 2009. p. 54

${ }^{25}$ SILVA, José Afonso da. Curso de direito constitucional. 19a ed. São Paulo: Malheiros Editores, 2001. p. 557-561.
} 
da Democracia representativa (eleições) e participativa (referendo e plebiscito); d) controle do bom funcionamento dos poderes públicos e da regularidade no exercício de suas competências constitucionais; e e) o equilíbrio da federação. ${ }^{26}$

O mestre português Canotilho também apresenta uma noção de justiça constitucional, aliada a um exame analítico de suas principais funções. Neste sentido:

a título de noção tendencial e aproximativa, pode definir-se justiça constitucional como o complexo de actividades jurídicas desenvolvidas por um ou vários órgãos jurisdicionais, destinadas à fiscalização da observância e cumprimento das normas e princípios constitucionais vigentes. ${ }^{27}$ (grifos do autor)

Verifica-se, desde logo, que a ideia de jurisdição constitucional como defesa da Constituição está vinculada ao contexto histórico e normativo sob exame. Isto porque defender a Constituição significa, dentre outras coisas, preservar o conteúdo ali consagrado, o que pode variar de acordo com o texto em voga, além do grau de desenvolvimento do constitucionalismo de determinado país. Preservar a Constituição de um Estado Liberal, com certeza, não é a mesma coisa que preservar a Constituição de um Estado Social, e assim por diante.

Por essa razão, tais concepções possuem um enfoque nas características da justiça constitucional e não em um conceito atemporal e universal, já que algumas funções permanecem ao longo dos anos, enquanto outras perdem fôlego e novas surgem.

Vital Moreira deixa clara a perspectiva histórica da justiça constitucional em razão do conteúdo constitucional consagrado, aduzindo que seu papel originário é:

fazer prevalecer a Constituição contra os atos do poder em três domínios característicos, isolada ou conjuntamente: os direito individuais, a separação dos poderes sobretudo entre o poder legislativo e o poder executivo, a definição de fronteiras entre os poderes federais e os dos Estados-membros no caso das federações. ${ }^{28}$

\footnotetext{
${ }^{26}$ MORAES, Alexandre de. Legitimidade da justiça constitucional. In: MARTINS, Ives Gandra da Silva (coord.). As vertentes do direito constitucional contemporâneo. Rio de Janeiro: América Jurídica, 2002. p. 560-561.

${ }^{27}$ CANOTILHO, J. J. Gomes. Direito constitucional e teoria da Constituição. $7^{\mathrm{a}}$ ed. Almedina. p. 892 e ss. Posteriormente, o autor trata como temas mais relevantes o controle de constitucionalidade, os conflitos federativos, a defesa dos direitos fundamentais e a tutela das liberdades.

${ }^{28}$ MOREIRA, Vital. Princípio da maioria e princípio da constitucionalidade: legitimidade e limites da justiça constitucional. In: (vários autores), Legitimidade e legitimação da justiça constitucional. Coimbra: Coimbra editora. 1995. p. 185
} 
Em seguida, prega o autor que, hodiernamente, para a justiça constitucional ser instrumento e garantia da Constituição em sua integralidade, ela precisa alargar as suas funções e atuar na garantia dos direitos constitucionais da oposição; na posição constitucional das regiões e dos municípios; no direito das minorias e na defesa da pluralidade e heterogeneidade social e cultural. $^{29}$

Assim, constatado que a ideia de defesa da Constituição tem inclinação circunstancial, não podemos adotá-la no presente estudo, uma vez que o Supremo Tribunal Federal e a Suprema Corte estadunidense atuam em contextos normativos e históricos significativamente distintos, e deste modo a ideia de defesa somente poderia ser tomada em sentido amplíssimo, o que prejudicaria o trabalho pela sua vaguidão.

A despeito dessas duas compreensões de justiça constitucional expostas, outros conceitos podem ser encontrados na doutrina, mas eles estão vinculados a escopos e contextos acadêmicos específicos que impedem nossa filiação. ${ }^{30}$

Desta maneira, necessitamos de uma visão distinta de jurisdição constitucional que integre e complemente as ideias de aplicação e defesa, permitindo englobar toda a atuação dos órgãos judiciários supremos do Brasil e dos EUA.

A solução pode ser encontrada na associação da ideia de jurisdição à de competência do órgão judiciário, já que torna mais precisos e claros os casos em que a Corte pode atuar e os modos como pode preservar a Carta Magna.

Essa concepção é utilizada por parte da doutrina brasileira e estadunidense, como pode ser visto em Friendenthal, para quem a "jurisdiction deals with the power of a court to hear and dispose of a given case". ${ }^{31}$ No mesmo sentido, Field assume um emprego indistinto entre as expressões "competency of the Court" e "the court's jurisdiction over the subject matter", ${ }^{32}$ No Brasil, um dos sentidos conferidos a jurisdição por Maria Helena Diniz é "soma de atividades e de atribuições do juiz". 33

\footnotetext{
${ }^{29}$ MOREIRA, Vital. op. cit. p. 186-187.

${ }^{30}$ Neste sentido, o conceito de Tavares: “'Justiça Constitucional' tem uso identificado, nesta pesquisa, para designar apenas a Justiça desenvolvida no âmbito do Tribunal Constitucional, incluindo o estudo de sua origem histórica, seu posicionamento entre os poderes, suas principais categorias funcionais, morfologia e natureza da atividade do Tribunal Constitucional, processo decisório e suas regras, legitimidade democrática e perspectivas" TAVARES, André Ramos (coord.). Teoria da justiça constitucional. São Paulo: Saraiva, 2005. p. 151.

31 "jurisdição refere-se ao poder de uma corte conhecer e julgar um caso" (tradução nossa). FRIEDENTHAL, Jack H.; KANE, Mary Kay; MILLER, Arthur R. Civil procedure. Saint Paul, Minnesota: Publishing Co., 1985. p. 11.

32 "competência da Corte" e "jurisdição da Corte sobre o litígio" (traduções nossas). FIELD, Richard E.; KAPLAN, Richard; CLERMONT, Kevin M. Materials for a basic course in civil procedure. 7. ed. Westbury, New York: The Foundation Press, 1985. p. 858.

${ }^{33}$ DINIZ, Maria Helena. Dicionário jurídico. $3^{\text {a }}$ ed. rev. at. e aum. São Paulo: Saraiva, 2008. p. 27.
} 
Deste modo, adotaremos o seguinte conceito: jurisdição constitucional é a competência atribuída positivamente ao órgão judiciário supremo de um país.

Dois esclarecimentos devem necessariamente acompanhar a leitura do conceito:

I) o termo positivamente indica toda competência prevista em norma jurídica válida e em vigor, seja na Constituição ou em leis ordinárias, visto que a maior parte da competência recursal da Suprema Corte está prevista em lei federal e, no Brasil, as chamadas ações constitucionais têm grande desenvolvimento em lei infraconstitucional.

II) por órgão judiciário supremo designamos, precisamente, o Supremo Tribunal Federal do Brasil e a Suprema Corte dos Estados Unidos da América. Não avaliaremos a jurisdição dos Tribunais inferiores desses países ou juízes de primeiro grau, embora eles possam ter competência definida na Constituição e exerçam controle de constitucionalidade.

Feitas as devidas ponderações, acreditamos que o conceito exposto tenha consistência e adequação suficiente para o estudo proposto nesta dissertação, já que é aplicável tanto na realidade brasileira quanto na estadunidense e engloba a ideia de aplicação da norma e defesa da Constituição restrita às competências positivadas, tornando mais precisas e identificáveis as possibilidades de atuação da Corte de acordo com a mudança legislativa.

Além do mais, vale a pena repetir, não há a pretensão de ser este um conceito universal de jurisdição constitucional.

\section{$1.3 \mathrm{O}$ conceito de ativismo judiciário}

Em nossa pesquisa, encontramos a atribuição de múltiplos sentidos para a expressão ativismo judiciário ${ }^{34}$, variando entre noções rudimentares a conceitos rigorosamente construídos e por vezes alicerçados em pressupostos teóricos específicos que não podem ser desprezados.

Deve ser ressaltado que há uma confusão terminológica que prejudicou significativamente nossa pesquisa, consubstanciada no uso indiscriminado de diversas expressões correlatas, tais como: ativismo judicial (ou judiciário ou jurisdicional),

\footnotetext{
${ }^{34}$ Tomaremos como sinônimas as expressões ativismo judiciário, ativismo judicial e ativismo.
} 
judicialização da política, politização da justiça, criacionismo judicial, ditadura de juízes, juristocracia e supremocracia.

Nesse caso, uma crítica metodológica severa se impõe, pois muitas vezes não há clareza e coerência no emprego dessas expressões, utilizadas arbitrariamente e sem consistência. É comum afirmar haver distinções entre os termos, sem nunca indicar quais são elas, ou adotá-las expressamente mas não empregá-las fielmente ao longo do texto. Tudo isso, frequentemente associado a um discurso prolixo e inconclusivo.

Há, portanto, um cenário confuso e pouco responsável no emprego dessas expressões, que torna o estudo sistemático excessivamente complexo e, em muitos casos, inviável.

Todo esse quadro narrado nos impõe uma adoção tópica de conceito de ativismo judiciário, ou seja, restrita aos pressupostos e finalidades deste trabalho.

Não pretendemos, em absoluto, construir um conceito universal de ativismo ou asseverar quais daqueles presentes na doutrina estão certos ou errados ${ }^{35}$, visto que isso exigiria enfrentar uma série de obstáculos metodológicos (por vezes instransponíveis pelas razões já expostas), que não cabem na presente dissertação.

Assentadas estas premissas, importa destacar que, em razão das inúmeras definições de ativismo encontradas em nossa pesquisa e a inviabilidade de confrontá-las diretamente, optamos por reuni-las ao redor de quatro concepções principais. Faremos referência expressa quando houver pressupostos teóricos específicos que não estão por elas englobadas, ou quando um conceito reunir várias concepções em si.

À medida que forem sendo expostas, avaliaremos sua consistência com os elementos de conceito por nós estabelecidos (conteúdo, delimitação e identificação) para que possamos, ao final, julgar sua adequação às finalidades do trabalho.

Exporemos as quatro concepções de forma aleatória, não havendo qualquer ordem de importância, surgimento histórico ou pressuposto teórico entre elas.

\footnotetext{
35 O binônimo é empregado apenas para enfatizar uma eventual pretensão desde já abandonada. Tecnicamente, dada a complexidade do tema, não acreditamos ser adequado utilizar tais categorias, motivo pelo qual analisaremos os conceitos com diversos requisitos, em especial, sua coerência e consistência.
} 
1.3.1 Ativismo como imposição da vontade do juiz e não da lei

A primeira ideia de ativismo é a de decisão judicial baseada na imposição $d a$ vontade do juiz e não na vontade da lei (the will of the judge and not the will of the law), ou seja, há um voluntarismo judicial que superpõe as preferências e ideologias do juiz em detrimento do que prevê a lei e a Constituição, assim como seus edificadores (os legisladores).

Este talvez seja o sentido mais difundido de ativismo, estando presente tanto de forma explícita quanto implícita na maioria dos conceitos. Citamos alguns deles presentes na doutrina e nos dicionários jurídicos:

[...] a philosophy of judicial decision-making whereby judges allow their personal views about public policy, among other factors, to guide their decisions, usu. with the suggestion that adherents of this philosophy tend to find constitutional violations and are willing to ignore precedent. ${ }^{36}$ (grifos nossos)

Judicial activism, as the concept is typically used, means deciding a case contrary to the plain meaning of the Constitution in order to promote the judge's political preferences. ${ }^{37}$ (grifos nossos)

[...] the practice in the judiciary of protecting or expanding individual rights through decisions that depart from established precedent or are independent of or in opposition to supposed constitutional or legislative intent $[\ldots] .^{38}$ (grifos nossos)

Essa concepção é largamente amparada pela doutrina originalista dos $\mathrm{EUA}^{39}$, para quem o juiz deve sempre buscar na vontade da Constituição ou da lei a resolução do caso concreto. Em havendo dúvida quanto ao sentido literal de um texto normativo, deve o juiz

\footnotetext{
${ }^{36}$ Black's Law Dictionary, apud VALLE, Vanice Regina Lírio do (org.). Ativismo jurisdicional e o Supremo Tribunal Federal. Curitiba: Juruá, 2009. p. 19, nota de rodapé.

37 "Ativismo judicial, como o conceito é tipicamente utilizado, significa decidir um caso contrariamente a vontade clara da Constituição de modo a promover as preferências políticas dos juízes" (tradução nossa). ROOSEVELT III, Kermit. The myth of judicial activism: making sense of Supreme Court decisions. Yale University Press. 2006. p. 38.

38 "a prática do Judiciário de proteger ou expandir direitos individuais por meio de decisões que se afastam ou são independentes dos precedentes consolidados, ou estão em oposição a suposta vontade constitucional ou legislativa" (tradução nossa). Merriam-Webster's Dictionary of Law apud VALLE, Vanice Regina Lírio do. op. cit. p. 19, nota de Rodapé.

${ }^{39}$ SCALIA, Antonin. op.cit.
} 
buscar a resposta na vontade do legislador, já que é dali que a norma se originou e é ele (legislador) o legítimo representante do povo soberano.

O juiz, portanto, deve assumir um papel asséptico e imparcial quanto ao conteúdo normativo, afastando suas próprias convicções no ato de interpretar a lei e aplicá-la no caso concreto. Trata-se de uma concepção histórica enraizada no juiz de Montesquieu como "la bouche que prononce les paroles de la loi" ${ }^{40}$, embora a doutrina originalista não a adote integralmente, já que nega um papel tímido, porém ativo do juiz vinculado à investigação do sentido da norma em si ou das intenções do legislador.

No Brasil, embora não haja uma disseminação da doutrina originalista, as mesmas ideias estão presentes no campo da hermenêutica jurídica, tanto no método gramatical ou exegético, quanto na doutrina da mens legis e mens legislatoris. ${ }^{41}$

Essa visão não é alheia a críticas, sendo inúmeros os trabalhos que a contrapõem.

Em primeiro lugar, há o problema de se aferir a vontade da Constituição em razão de seu caráter principiológico e valorativo, consagradora de termos subjetivos e flexíveis que a tornam um texto histórico altamente especulativo.

Não se mostra plausível afirmar que existe um sentido certo, objetivo e imutável para diversos enunciados normativos, como é o caso do direito à igualdade ou a forma republicana de Estado, empregados tanto na Constituição brasileira quanto na estadunidense. Os enunciados abertos, como expressão de valores e princípios, não gozam de um rigorismo tal que permita uma aferição precisa e consensual de seu sentido, sendo altamente manipulados de acordo com os intérpretes da Constituição.

A hermenêutica jurídica, ao contrário do que muitos pensam, é propulsora dessas especulações ao invés de conduzir o operador do direito a uma resposta única e correta, já que fornece diversos instrumentos investigativos que fundamentam racionalmente vários sentidos provenientes do texto legal. Lembramos, para não deixar dúvidas, que interpretar

\footnotetext{
40 "a boca que pronuncia as palavras da lei” (tradução nossa). MONTESQUIEU, Charles-Louis de Secondatt, barão de la Brède e de. De l'esprit des loi. vol I. Mesnil-sur-l'Estrée, França: Gallimard, 1995. p 337. Para a correta compreensão de Montesquieu é preciso considerar que o nobre francês se referia às leis como clarividentes ("clairvoyante") ou precisas ("précis") e que, portanto, os juízes deveriam aplicá-las cegamente. Este raciocínio lógico não pode ser adotado com o mesmo vigor quando as leis são imprecisas e vagas, o que torna a questão mais complexa e a remissão a Montesquieu parcial.

${ }^{41}$ A maior parte da doutrina trata o método gramatical ou exegético como sinônimos, designando-os como uma interpretação literal da lei, ou seja, baseada apenas no texto e sem referência a elementos exteriores. Todavia, há doutrina que associa o método exegético à investigação da vontade do legislador (mens legislatoris). Ver a este respeito MAZOTTI, Marcelo. As escolas hermenêuticas e os métodos de interpretação das leis. Barueri: Minha Editora, 2010. p. 55-59.
} 
significa investigar o sentido de um texto, o que não quer dizer encontrar a verdade científica dos fatos. $^{42}$

Kermit Roosevelt III assevera que poucos casos constitucionais possuem uma resposta clara e precisa ${ }^{43}$, e cita as palavras do sábio jurista Oliver Wendell Holmes que, de forma concisa e prática, teria dito que "general propositions do not decide concrete cases". 44

John Hart Ely faz um minucioso estudo sobre algumas cláusulas abertas da Constituição dos $\mathrm{EUA}^{45}$, como a due process clause e a equal treatment clause, relatando seu surgimento histórico e as discutíveis interpretações que lhe foram dadas ao longo dos anos, nem sempre gozando de coerência e consistência. ${ }^{46}$

Portanto, verificada a impossibilidade de se aferir um sentido claro e consensual de inúmeros enunciados constitucionais, a doutrina ativista costuma asseverar a suplementação dessas ambiguidades com a vontade originária do legislador. Ou seja, se não ficou claro o que está escrito no texto, devemos perguntar para quem o escreveu.

Neste aspecto, diversos autores rejeitam a validade dessa operação, como por exemplo, John Hart $\mathrm{Ely}^{47}$, nos EUA, e Carlos Maximiliano ${ }^{48}$, no Brasil, para quem não é possível encontrar um sentido unívoco nas deliberações parlamentares, onde há um jogo de interesses de tal monta complexo e conflitante que o resultado normativo não é uma simples soma coerente de fatores ou uma adesão a uma vontade única predominante ${ }^{49}$.

\footnotetext{
${ }^{42}$ Deve-se distinguir, neste caso, aquilo que é "justo", "correto" ou "verdadeiro" daquilo que é o sentido da norma, operação incômoda e pouco realizada pela maioria dos juristas que, ao invés de investigar o sentido do texto, avaliam sua pertinência aos valores supracitados. Para uma análise das concepções de interpretação e as ideologias presentes nos métodos hermenêuticos filosóficos e jurídicos, ver MAZOTTI, op. cit.

43 "The plausibility of the charge of activism thus depends at least implicitly on the idea that there is a clearly correct answer (frequently called 'the plain meaning of the Constitution') that judges are disregarding. And the basic reason that the term 'activism' has no place in a serious discussion is that relatively few significant or controversial cases posses clear right answers" ("a plausibilidade da crítica do ativismo depende - ao menos implicitamente - da ideia de que há uma resposta correta (frequentemente chamada do 'claro sentido da Constituição') e que os juízes estão deprezando-o. E a simples razão pela qual o termo 'ativismo' não tem espaço em uma discussão séria é que relativamente poucos e significantes ou controversos casos possuem uma resposta correta clara. (tradução nossa). ROOSEVELT III, Kermit. op. cit. p. 15

44 “proposições gerais não decidem casos concretos”. ROOSEVELT III, Kermit. op. cit. p. 18.

${ }^{45} \mathrm{O}$ sentido de cláusula empregada nos EUA, dentre nós, estaria próximo dos termos princípios ou direitos, a depender da cláusula específica que se está tratando.

${ }^{46}$ ELY, John Hart. Democracy and distrust. Cambridge, Massachusetts: Harvard University Press, 1980. p. 14-41.

${ }^{47}$ ELY, John Hart. op. cit.

${ }^{48}$ MAXIMILIANO, Carlos. Hermenêutica e aplicação do direito. $8^{\text {a }}$ ed. São Paulo: Livraria Freitas Bastos, 1965.

${ }^{49}$ Fazemos aqui menção a teoria de Dworkin acerca da intenção do legislador, realizando a desconstrução dos sentindo que lhe são comumente atribuídos, reformulando-os e propondo uma nova visão baseada em seus conceitos de integralidade e equidade. Ver a respeito, DWORKIN, Ronald. Law's empire. Sine loco: The Belknap Press of Harvard University Press, 1986, em especial, o capítulo IX.
} 
Primeiramente, é preciso assentar que o legislador a que se faz referência é um ente irreal, já que nenhuma lei emerge da vontade de uma pessoa, mas centenas delas que aprovam determinado texto por razões diversas e nem sempre concordantes, o que torna artificial a investigação com base na vontade de um ente que não existe.

Além do mais, a investigação dos documentos ou discursos proferidos em prol da aprovação da lei é um procedimento parcial, já que relata a opinião de apenas um ou alguns parlamentares, não condizendo com o todo legislativo.

Nos dizeres de Maximiliano,

Em uma das forjas da lei, no Parlamento, composto, em regra, de duas Câmaras, fundem-se opiniões múltiplas, o conjunto resulta de frações de ideias, amalgamadas; cada representante do povo aceita por um motivo pessoal a inclusão de palavra ou frase, visando a um objetivo particular a que o mesmo se presta; há o acordo aparente, resultado de profundas contradições. Bastas vezes a redação final resulta imprecisa, ambígua, revelando-se o produto da inelutável necessidade de transigir com exigências pequeninas a fim de conseguir a passagem da ideia principal.

Se descerem a exumar o pensamento do legislador, perder-se-ão em um bárato de dúvidas maiores ainda e mais inextrincáveis do que as resultantes do contexto. Os motivos que induziram alguém a propor a lei, podem não ser os mesmo que levaram outros a aceitá-la $\left[\ldots . .{ }^{50}\right.$

Ely assevera que a Constituição estadunidense, para ser corretamente interpretada, deve considerar a vontade de todos os Congressistas que votaram pela aprovação de seu texto, assim como todas as Assembléias Legislativas Estaduais que o ratificaram, o que envolve um número elevado de pessoas tão diferentes em contextos tão distintos que não é possível qualquer aferição confiável de suas intenções ${ }^{51}$.

Se é certo que a vontade da lei e do legislador gozam de elevado teor especulativo, o mesmo se pode dizer acerca da imposição da vontade do juiz. Afinal de contas, como investigar o sentido de princípios como igualdade ou liberdade sem fazer uso da própria subjetividade e consciência histórica?

Não é possível a total separação entre o texto e o intérprete como é desejado por esta visão, pois a aferição do sentido implica em um movimento dialético de construção entre o intérprete e o texto que não permite a existência de linhas demarcatórias rígidas. Ainda mais quando se trata de princípios (valores) que têm concepções formuladas historicamente, gerando preconceitos que não permitem distinguir qual o sentido

\footnotetext{
${ }^{50}$ MAXIMILIANO, Carlos. op. cit. p. 35.

${ }^{51}$ ELY, John Hart. op. cit. p. 17.
} 
originário atribuído pelo autor, o apreendido pelo leitor e de um eventual sentido autônomo do texto em si, sendo certo que todos esses entes estão inseridos em um fórum da tradição da história e da linguagem, no sentido gadameriano da expressão. ${ }^{52}$

Deste modo, o conceito de ativismo como imposição da vontade do juiz em detrimento da lei esbarra nos fortes argumentos das doutrinas que não acreditam ser possível encontrar objetivamente a vontade da lei ou do legislador e separá-las daquela do juiz.

Isto não quer dizer que, fatalmente, o juiz pode impor suas convicções a seu belprazer, o que deve ser reprovado em um Estado moderno e democrático alicerçado sob o governo das leis e não dos homens.

A questão, portanto, não é concordar ou não com a ideia de que o juiz deve aplicar a lei e não as suas convicções, posto que o pensamento assim formulado é reducionista e não enfrenta o problema da interpretação e aplicação dos enunciados abertos, além das omissões normativas.

Isto nos leva à conclusão de que a concepção de ativismo até agora exposta não goza da consistência por nós almejada, tendo conteúdo controverso e não permitindo identificar as decisões judiciais sob ele abarcadas.

\subsubsection{Ativismo como expansão do Poder Judiciário}

A expansão do Poder Judiciário é uma expressão largamente utilizada pela doutrina em âmbito nacional e internacional, cujo significado pode variar consideravelmente. Podemos identificar, apenas de maneira aproximativa, uma adesão à ideia de ampliação da função jurisdicional para áreas que tradicionalmente não eram de sua competência.

Desde logo se mostra difícil aferir qual a relação precisa entre o ativismo e a expansão do Poder Judiciário, já que ambos não têm traços distintivos bem definidos na doutrina, muitas vezes sendo tomados como sinônimos, outras vezes como fenômenos correlatos ou decorrências um do outro (relação de causa e efeito). Ademais, os estudos

\footnotetext{
${ }^{52}$ Para uma leitura da visão hermenêutica fenomenológica, ver GADAMER, Hans-Georg. Verdade e Método I: traços fundamentais de uma hermenêutica filosófica. Tradução de Flavio Paulo Meurer. $6^{\mathrm{a}}$ ed. Petrópolis, RJ: Editora Vozes, Bragança Paulista, SP: Editora Universitária São Francisco, 1997.
} 
nacionais sobre expansão ainda trazem em seu bojo os fenômenos da judicialização da política e da politização da justiça, tecendo poucas considerações conceituais sobre eles.

Assim, é necessário elencar um parâmetro mais preciso de expansão, como o faz o prof. Elival da Silva Ramos, que adota um viés dogmático e normativo em seu conceito de ativismo judicial.

[...] por ativismo judicial deve-se entender o exercício da função jurisdicional para além dos limites impostos pelo próprio ordenamento que incumbe, institucionalmente, ao Poder Judiciário fazer atuar, resolvendo litígios de feições subjetivas (conflito de interesse) e controvérsias jurídicas de natureza objetiva (conflitos normativos). Há, como visto, uma sinalização claramente negativa no tocante às práticas ativistas, por importarem na desnaturação da atividade típica do Poder Judiciário, em detrimento dos demais Poderes. ${ }^{53}$

Infelizmente, a definição exposta não poderá ser adotada em nosso trabalho, por duas razões: primeiro, porque, nos EUA, o Judiciário não julga controvérsias de natureza objetiva (não há controle abstrato de constitucionalidade), devendo o conceito por nós adotado atender tantos as necessidades nacionais quanto as estadunidenses, e, segundo, porque a leitura sistemática da obra demonstra que o autor buscou identificar, analiticamente (mas não de forma exaustiva), o que considera expressão de ativismo judicial no sistema jurídico brasileiro, com foco na jurisdição do Supremo Tribunal Federal. $^{54}$

Deste modo, partindo-se da ideia de expansão sob o viés dogmático e normativo, cumpre-nos investigar se há a possibilidade de se erigir um outro conceito de ativismo que seja aplicável tanto no Brasil quanto nos EUA.

De imediato, a visão normativa fatalmente sucumbirá, posto que o direito positivo é significativamente distinto no Brasil e nos EUA, onde as Constituições e legislações ordinárias conferem competências diversas aos Tribunais. O que pode ser exercício regular da jurisdição para um, pode ser considerado ativismo para outro.

Já no que tange o viés dogmático, a doutrina constitucionalista costuma realizar uma leitura da expansão do Judiciário tomando como ponto de partida a teoria clássica da

\footnotetext{
${ }^{53}$ RAMOS, op. cit.. p. 129.

54 RAMOS, op. cit. "[...] não há na manipulação de eficácia temporal das decisões de controle, em si, nenhuma manifestação de ativismo judicial” (p. 202). Quanto às sentenças aditivas, assevera que, a priori, não há ativismo, embora reconheça haver uma linha tênue que possa propiciá-lo (p.219-220). Quanto às sentenças substitutivas, considera-as verdadeiro exercício de ativismo judicial (p. 223).
} 
tripartição de poderes, asseverando que a expansão (ativismo) ocorre quando há uma invasão indevida das atribuições de um Poder sobre o outro.

Todavia, como preleciona Manoel Gonçalves Ferreira Filho, a realidade constitucional brasileira não aponta para a consagração dessa visão clássica na Carta de 1988, conferindo ao Judiciário um papel distinto do tradicionalmente desempenhado:

Como em todos os Estados de derivação liberal, estrutura-se o poder político no Brasil de acordo com a separação de poderes. [...] Entretanto, essa doutrina não é unívoca. Ou, pelo menos, ela não é em toda parte interpretada da mesma forma. Certamente, por exemplo, o que decorre do cap. VI do livro XI do Espírito das Leis, não coincide com o que estabelece a Lei Magna vigente $[. ..]{ }^{55}$ (grifos do autor)

Mais adiante, assevera que:

Quanto à própria função de julgar trouxe a Constituição nova um outro enfoque, bem distinto do tradicional. Obviamente, continua este Poder incumbido primacialmente de julgar. [...] Contudo, a Carta the deu, mesmo nessa função típica, um certo distanciamento em relação à lei que não admitia a doutrina clássica.[...] Assim, pode hoje o magistrado inquietar-se sobre a razoabilidade da lei, a proporcionalidade dos encargos que acarreta, etc. quando antes não lhe cabia senão ser a voz da lei. ${ }^{56}$ (grifos nossos)

Destarte, o viés puramente dogmático, quando mal empregado, inviabiliza o tratamento adequado do fenômeno da expansão do Judiciário, não porque este não pode ser visto historicamente, analisada a doutrina clássica em seu nascedouro até os dias atuais. Mas porque compara, diretamente e alheio aos contextos históricos e normativos, teorias seculares com realidades atuais, trabalho este metodologicamente inadequado.

Além do mais, Brasil e EUA tiveram influências diversas em sua concepção original de separação de poderes, sendo muito presente dentre nós a obra de Montesquieu $^{57}$ e nos EUA, a obra de Hamilton. ${ }^{58}$

Concluímos, portanto, que, à exceção de doutrinas específicas que guardam consistência lógica interna, não há um tratamento conceitual rígido quanto aos fenômenos do ativismo e da expansão do Poder Judiciário, sendo que os parâmetros normativos e

\footnotetext{
${ }^{55}$ FERREIRA FILHO, Manoel Gonçalves. op. cit. p. 22.

${ }^{56}$ FERREIRA FILHO, Manoel Gonçalves, $i b$. . p. 30.

${ }^{57}$ MONTESQUIEU, Charles-Louis de Secondatt, barão de la Brède e de. op. cit.

${ }^{58}$ HAMILTON, Alexander; MADISON, James; JAY, John. The federalists papers. Signet Classics, 2003.
} 
dogmáticos não permitem um estudo adequado das distintas realidades brasileira e estadunidense.

\subsubsection{Ativismo como criação de direito}

A terceira compreensão associa o ativismo à criação de direito pelo juiz, ou mais enfaticamente, ao exercício do poder legislativo pelo Judiciário.

Quem adota esta visão é o cientista político estadunidense Wolfe, para quem "Judicial activism, in this framework, is the exercise of 'legislative' power by courts in constitutional cases" ${ }^{, 59}$, assumindo que tal visão é justificadamente controversa, e é adotada dentro de um contexto teórico específico. ${ }^{60}$

Na obra Juizes Legisladores? ${ }^{61}$, Mauro Cappelletti trata do tema do criacionismo, visto como o "problema da 'criatividade' da função jurisdicional, ou seja, da produção do direito por obra dos juizes." 62 Inobstante seu foco não ser declaradamente o ativismo judicial, os argumentos são a ele emprestáveis, posto que o autor acaba por analisar todo o contexto do ativismo, em especial, as relações entre os Poderes e suas consequências para a teoria democrática.

Ocorre que o próprio Cappelletti assevera que interpretar a lei é, em certa medida, criar a lei e que, deste modo, "a única diferença possível entre jurisdição e legislação não é, portanto, de natureza, mas sobretudo de frequencia ou quantidade, ou seja, de grau (...)., 63

Isto porque, estando o juiz diante de um caso em que não há uma resposta normativa clara e precisa, deve ele procurar no Direito uma resolução para o litígio jurídico à sua frente, fazendo uso de diversos métodos interpretativos que, ao fim e ao cabo, permitirão a escolha de um sentido normativo que não estava expresso à primeira vista.

\footnotetext{
59 "Ativismo judicial, neste contexto, é o exercício do poder legislativo pelas cortes em demandas constitucionais" Deve ser ressaltado que o autor tem um estudo conceitual rigoroso e o insere em um contexto específico (tradução nossa). WOLFE, Christopher. Judicial activism: bulwark of freedom or precarious security?. Rev. ed. Rowman \& Littlefield Publishers, 1997. p.30.

${ }^{60}$ WOLFE, Christopher. op. cit. p. 1-32.

${ }^{61}$ CAPPELLETTI, Mauro. op.cit.

${ }^{62}$ CAPPELLETTI, Mauro. ib.. p. 13.

${ }^{63}$ CAPPELLETTI, Mauro. ib. p. 26
} 
Este sentido encontrado, de acordo como o olhar subjetivo do intérprete, poderá ser considerado como imanente a norma e, portanto, válido, ou exterior a ela, caso em que se considera que o juiz injetou-lhe um conteúdo, criando uma nova norma.

O fato é que não é possível delimitar com rigor a linha tênue que separa o encontro de um sentido contido na lei daquele que lhe foi atribuído arbitrariamente, posto que essa operação tem elevada dose subjetiva e especulativa (como é da natureza da hermenêutica).

Sendo assim, a questão do criacionismo judicial traz à tona o problema da interpretação dos enunciados abertos e da imposição da vontade do juiz, já analisados anteriormente.

Além do mais, no Brasil, a legislação parece consentir com um certo nível de edificação de enunciados normativos pelo Supremo Tribunal Federal, como é o caso da permissão para modular efeitos, proferir sentenças aditivas e, mais enfaticamente, editar súmulas vinculantes com teor abstrato, geral e cogente a todo território nacional, o que se aproxima das características de uma norma jurídica.

Pelas razões expostas, não adotaremos um conceito de ativismo com base na criação do direito pelo juiz.

1.3.4 Ativismo como realização de políticas públicas

A quarta compreensão de ativismo designa-o como a realização de políticas públicas pelos juízes, sendo diversas as conotações aqui conferidas.

Ela pode significar, em um primeiro momento, a criação judicial ilegítima de políticas públicas não estabelecidas formalmente pela Constituição ou pelos demais Poderes, como geralmente se alega ser o caso do fim da segregação racial (Brown vs Board of Education of Topeka), do direito ao aborto (Roe vs. Wade) e da união homoafetiva (ADI 4277). ${ }^{64}$

Outrossim, ela pode assumir contornos mais suaves, em que o judiciário promove mudanças ou anula as políticas públicas criadas por outros órgãos governamentais, sem ter um papel precursor mais incisivo, conforme definição esposada pelo célebre cientista político estadunidense Lawrence Baum:

\footnotetext{
${ }^{64}$ Não se está aqui a afirmar que tais decisões são ativistas, mas apenas que elas são comumente citadas nas obras que tratam da realização de políticas públicas pelos juízes.
} 
What I mean by activism is that a court makes significant changes in public policy, especially in policies that the other branches have established. One form of activism involves the Court's use of judicial review, its power to overturn acts of other policymakers because they violate the Constitution. ${ }^{65}$

A dificuldade dessa compreensão é, em primeiro lugar, definir o que são políticas públicas e, ao final, determinar se o juiz pode ou não realizá-las.

A princípio, poder-se-ia dizer que é responsabilidade do Legislativo estabelecer as políticas pública e do Executivo concretizá-las, não cabendo o Judiciário realizá-las. Este raciocínio, contudo, está arraigado na concepção dogmática de separação de poderes por nós já rechaçada, visto que não enfrenta a questão da aplicação e interpretação das cláusulas constitucionais abertas e, no caso particular do Brasil, não considera as competências estabelecidas no texto constitucional hodierno, em que as inúmeras mudanças legislativas promoveram, explicitamente, um reposicionamento dos Poderes.

A Constituição brasileira, por exemplo, apresenta diversas armadilhas para a separação estanque clássica entre os Poderes, como é o caso do comando presente no art. $5^{\circ}, \S 1^{\circ 66}$, que determina a aplicabilidade imediata de diversos direitos do cidadão, inobstante o conteúdo indeterminado de vários deles e a necessidade da ação de outros órgãos governamentais para sua implementação.

Outra situação intrigante é o caso da consagração de direitos públicos subjetivos em sede de direitos sociais, em especial a saúde e a educação. Nesses casos, o Supremo Tribunal Federal já determinou que a concessão de uma vaga à creche, por exemplo, não significa a criação de uma política pública pelo juiz, mas a simples obediência à norma constitucional que assim o exige. ${ }^{67}$

Embora esta decisão judicial não goze de plena aceitação, a fato é que o texto constitucional positivado interfere significativamente no maior ou menor exercício de ativismo pelo juiz, como só poderia acontecer. A utilização de termos enfáticos como autoaplicabilidade ou direito subjetivo conferem um maior grau de discricionariedade judicial, o que não pode ser desprezado em um estudo comparativo.

\footnotetext{
65 "O que eu designo por ativismo é quando uma corte faz significativas mudanças em políticas públicas, especialmente em políticas que os outros órgãos elaboraram. Uma forma de ativismo diz respeito ao uso do judicial review pela Corte, seu poder de superar atos de outros policymakers em razão de sua violação a Constituição" (tradução nossa). BAUM, Lawrence. The Supreme Court. 10 ed. Washington, DC: CQ Press, 2010. p. 162-163.

${ }^{66}$ Art. $5^{\circ}, \S 1^{\circ}, \mathrm{CF}$. As normas definidoras de direitos e garantias fundamentais têm aplicação imediata.

${ }^{67}$ AgRgRE 410.715.
} 
Deste modo, sendo certo que o desenho constitucional positivado no Brasil e nos EUA são bem diversos, fazendo com que as funções de aplicação e concretização da Constituição sejam bem diferentes entre um e outro, não é possível a adoção de um conceito único com base na realização de políticas públicas, a não ser que fosse tomada uma visão dogmática universal de separação de poderes no sentido liberal, o que por nós foi rechaçado.

\subsubsection{Outras concepções}

Por fim, há autores que aglutinam as ideias mencionadas em um conceito único ${ }^{68}$ ou preferem estudar o fenômeno a partir das características de seu agente, o juiz ativista. ${ }^{69}$ Inobstante as peculiaridades de cada conceito, são a eles plenamente aplicáveis as críticas já expostas.

Em especial, há a compreensão de ativismo como desrespeito à jurisprudência (precedents) das Cortes, querendo com isso designar as mudanças ilegítimas de posicionamentos (interpretações) dos Tribunais sobre determinada matéria, corroendo a segurança jurídica e a coerência jurisprudencial.

Trata-se de uma ideia enraizada na concepção de ativismo como imposição da vontade do juiz, uma vez que a crítica aqui é direcionada a uma postura arbitrária do julgador que modifica o posicionamento jurisprudencial a seu bel-prazer.

A crítica não permanecerá, por exemplo, quando houver mudança significativa na legislação que exija uma clara superação do entendimento anterior. Outros casos mais sensíveis envolvem a mudança do contexto histórico interpretativo e a chamada mutação constitucional.

\footnotetext{
68 "Em suas definições correntes, ativismo judicial é uma expansão do exercício da discricionariedade judicial, no qual um juiz ou um Tribunal cria ou estende um direito, afasta a aplicação da lei, ou utiliza-se do poder judicial para promover mudanças sociais (judicial overreaching) e intervir ou efetivar políticas públicas (policy making).” VITOVSKY, Vladimir Santos. Activismo judicial: só pecados e virtudes? Contribuições para uma teoria sociojurídica. In: OLIVEIRA, Umberto Machado de (coord.). Ativismo Judicial. Curitiba: Juruá Editora, 2010. p. 91

${ }^{69}$ Tratando das características do juiz ativista, a Pogrebinschi elenca: “a) use o seu poder de forma a rever e contestar decisões dos demais poderes do estado; b) promova, através de suas decisões, políticas públicas; c) não considere os princípios da coerência do direito e da segurança jurídica como limites à sua atividade". POGREBINSCHI, Thamy. Ativismo judicial e direito: considerações sobre o debate contemporâneo. Direito, Estado e Sociedade, Rio de Janeiro, n. 17, p. 121-143, ago/dez 2000. p. 122.
} 
Não adotaremos esta definição como um conceito de ativismo, pois ela não remete à integralidade do fenômeno, já que é tratada pela doutrina apenas como um de seus elementos ou como uma decorrência dos demais sentidos expostos.

Além do mais, há, nesse caso, um sério obstáculo quanto à distinção entre uma mudança constitucional "legítima" ou "ilegítima", o que impede a identificação das decisões ativistas com base nesse critério.

Por fim, cumpre salientar que inúmeras doutrinas tratam do ativismo como uma transgressão aos preceitos democráticos, aduzindo que a imposição da vontade do juiz viola a representatividade parlamentar, donde advém a legitimidade para as decisões políticas de um país e, consequentemente, de suas políticas públicas. Todavia, essas doutrinas tratam da transgressão democrática mais como uma decorrência do ativismo do que como sua causa, motivo pelo qual nenhuma delas apresenta um conceito puramente sob esse viés.

1.3.6 A concepção adotada de ativismo judiciário

Expostas as quatro compreensões que julgamos fundamentais para o estudo do ativismo, verificamos que todas elas são controversas quanto ao seu conteúdo e, mais importante, empregam termos pouco precisos e delimitados que não permitem uma identificação das decisões judiciais abarcadas pelo conceito.

Neste ponto, importa destacar o incômodo fato de que a quase totalidade das obras não dizem quais são as decisões ativistas, sendo as poucas remissões feitas de forma casuística ou indiretas.

Isto não quer dizer que os conceitos apresentados estão equivocados, mas apenas que não estão de acordo com os elementos por nós erigidos para a adoção de um conceito rigoroso e metodologicamente orientado.

Sendo assim, não utilizaremos nenhum conceito de ativismo, tampouco esposamos as concepções apresentadas. Todavia, para não comprometer o andamento do trabalho, adotaremos uma visão comumente empregada de ativismo para designar uma concepção difusa de exercício ilegítimo do poder judicial, em que o juiz toma decisões com base em suas convicções e ideologias pessoais, em detrimento dos termos da lei e da Constituição. 
Repetimos que não esposamos essa concepção de ativismo, mas a adotaremos neste trabalho, pois precisamos de alguma demarcação do nosso objeto de estudo (ainda que não totalmente precisa), além ser uma ideia frequente em quase toda doutrina (explícita ou implicitamente) e que se coaduna com a própria definição do vocábulo ativismo, que remete a uma atitude impositiva, uma afirmação cogente e incisiva da vontade direcionada ao atuar político. ${ }^{70}$

Quanto à jurisprudência analisada, não será utilizado nenhum critério rígido para sua escolha, sendo estudadas as decisões frequentemente mencionadas pela doutrina.

\subsection{A ênfase na atuação dos Tribunais}

Foi um sentimento de insatisfação que nos levou à opção por um estudo do ativismo sob o enfoque da atuação dos órgãos judiciários supremos do Brasil e dos EUA.

Isto porque, grande parte da doutrina jurídica utiliza uma visão notadamente dogmática sobre o ativismo, estudando e adotando premissas teóricas como verdades absolutas para, posteriormente, julgar a adequação das decisões do Poder Judiciário a essas premissas.

O raciocínio flui da seguinte maneira: existem teorias que originaram e justificam a existências das instituições. Para saber se elas (instituições) estão funcionando corretamente, é preciso uma investigação teórica e histórica de suas origens, de modo a alcançar sua exata compreensão e poder reprimir os desvios encontrados hodiernamente.

Esse caminho, embora válido, tem as suas limitações. Uma delas é a mal digerida distinção entre teoria e prática que costuma rondar esse tipo de abordagem, cuja compreensão equivocada pode levar a pretensões idealistas de acreditar que uma formulação teórica expressa em algumas palavras pode ser suficiente para descrever e reger toda a complexa gama de relações empíricas existentes.

\footnotetext{
${ }^{70}$ Neste sentido, vejamos duas definições dadas por dicionários ao termo. "ativista: militante político que é partidário de ativismo, ou da ação direta para conseguir o resultado por qualquer forma." SIDOU, J.M. Othon. Dicionário jurídico. Academia brasileira de letras jurídicas. 4. ed. Rio de Janeiro: Forense Universitária, 1997. p. 73.Dentre as várias definições de "activism" na língua inglesa, encontramos "(...) a doctrine or policy of advocating energetic action" (doutrina ou política que defende a ação enérgica). The oxford english dictionary. Vol. I. $2^{\mathrm{a}}$ ed. Oxford: Clarendon Press, 2000. p. 130.
} 
Tomemos, por exemplo, o caso da democracia, em que seus conceitos (ou noções) como governo do povo, pelo povo e para o povo ou vontade da maioria, gozam de excessiva fluidez e carecem de parâmetros claros e bem definidos para que se construa e efetive um governo verdadeiramente democrático.

Embora tais concepções tenham uma razão histórica e cumpram o seu papel pedagógico, evidentemente não condizem com a realidade, possuindo certa dose de artificialismo quanto às reais possibilidades de sua implementação ${ }^{71}$.

É conhecida na doutrina a crítica com relação às distorções da vontade popular decorrentes da eleição de representantes, já que eles podem ou não manifestar a vontade dos representados. Além do mais, não há mecanismos eficazes (que não seja aguardar as próximas eleições ou excepcionais impeachments) que impeçam a existência de um governo de representantes ao invés de um governo de representados.

Também não se deve olvidar (inobstante ser amarga a lembrança) que a vontade da maioria não foi esposada de forma incondicional pelas Constituições modernas, que delegaram considerável poder de decisão sobre temas importantíssimos a diversos órgãos não majoritários ${ }^{72}$ e previram a existência, no seio do próprio Parlamento, de mecanismos de tomada de decisões pela minoria, como é o caso do quorum de votação simples ou por bancadas. $^{73}$

Ao lado da democracia, outra concepção mal digerida nos estudos de ativismo e passível de críticas é a separação dos poderes, sobre a qual Bruce Ackerman já expressou com vigor sua opinião de que as doutrinas constitucionalistas estão presas a um modelo normativo das relações estatais baseado nos pensamentos de Madison e Montesquieu, asseverando que as ciências políticas tiveram um desenvolvimento mais rico ao não adotar tais pressupostos enrijecedores. ${ }^{74}$

Entre nós, encontramos a crítica incisiva do professor Virgílio Afonso da Silva, para quem o estudo do ativismo carece de uma leitura empírica e multidisciplinar que não se restrinja a discussões teóricas acerca da separação dos poderes ou da natureza das normas constitucionais. Neste sentido:

\footnotetext{
${ }^{71}$ Dahl apresenta uma visão cética quanto à possibilidade real de uma democracia perfeita. DAHL, Robert. Democracy and its critics. Yale University Press, 1989. p. 109. Sobre os limites da democracia, ver também a obra "A democracia possível” de Manoel Gonçalves Ferreira Filho (op. cit.).

${ }^{72}$ Por exemplo, as competências personalíssimas do Poder Executivo ou a delegação de poder normativo às agências reguladoras.

${ }^{73}$ Para um estudo acerca das inconsistências teóricas e inoperância prática da regra da maioria nos governos "democráticos", ver DAHL, Robert Alan. op. cit. capítulo X.

${ }^{74}$ ACKERMAN, Bruce. The new separation of powers. Harvard Law Review, Cambridge, vol. 113, n 3, pp. 633-729, janeiro de 2000.p. 637-638.
} 
An indicator that legal scholars have no interest in interdisciplinary and empirical researches - even when this would be vital for their object of study - is the fact that such researches on judicial decisions and on other relevant legal subjects are being made by scholars from other areas of knowledge. Political scientists, historians, anthropologists, and physicians are doing what we should do. While legal scholars - at least in Brazil - discuss the effectiveness of constitutional norms only through reading legal texts and law books, and try to find in the constitutional text some hint on their effectiveness; while they are still comparing the ideas of Lassalle and Hesse - a comparison that is meaningless for the discussion about social rights in a developing country in the beginning of the $21^{\text {st }}$ century; while most of the debate is (still!) marked by Montesquieu's ideas; while constitutional scholars discuss judicial activism and judicial restraint in an abstract manner, as if the correct answers were to be found on one of the sides of this dichotomy; while they still discuss the distinction between self-executing and not selfexecuting provisions (as if a constitutional norm could produce, without any legislative action or public policy, any effect within the field of social rights) - while they do all this, researchers from other areas of knowledge are studying concrete judicial decisions and their effects on the implementation of social rights like the right to health. And although the object of such researches are judicial decisions, there are generally no legal scholars involved in these researches. ${ }^{75}$

Sob este enfoque, o estudo de um caso considerado ativista, como Brown, por exemplo, não pode ser feito unicamente com base em uma eventual transgressão a um pretenso modelo de separação de poderes hamiltoniano, que sequer tem força normativa (já que a Constituição dos Estados Unidos nunca adotou os Federalists Papers ${ }^{76}$ como parte integrante de seu texto), além de ser um documento histórico altamente especulativo.

\footnotetext{
75 "Uma indicação de que os acadêmicos do direito não têm interesse em pesquisas interdisciplinares e empíricas - mesmo quando isto seria vital para seu objeto de estudo - é o fato de que os pesquisadores de decisões judiciais e de outros temas jurídicos relevantes estão sendo feitos por acadêmicos de outras áreas do conhecimento. Cientistas políticos, históricos, antropologistas e médicos [área da saúde] estão fazendo o que deveríamos fazer. Enquanto acadêmicos do direito - ao menos no Brasil - discutem a efetividade das normas constitucionais apenas por meio da leitura de textos legais e livros jurídicos e buscam encontrar no texto constitucional alguma pista de sua efetividade; enquanto eles ainda estão comparando as ideias de Lassale e Hesse - uma comparação que não tem sentido para a discussão sobre direitos sociais em países em desenvolvimento no século 21; enquanto a maior parte do debate é (ainda!) marcada pelas ideias de Montesquieu; enquanto acadêmicos constitucionalistas discutem ativismo judicial e contenção judicial de forma abstrata; como se a resposta correta pudesse ser encontrada em um dos lados desta dicotomia; enquanto eles ainda discutem a distinção entre provisões autoexecutáveis e não autoexecutáveis (como se uma norma constitucional pudesse produzir, sem qualquer ação legislativa ou política pública qualquer efeito no campo dos direitos sociais), enquanto tudo isso é feito, pesquisadores de outras áreas do conhecimento estão estudando decisões judiciais concretas e seus efeitos na concretização de direitos sociais, como o direito à saúde. E inobstante o objeto dessas pesquisas serem decisões judiciais, geralmente não há nenhum acadêmico do direito nelas envolvidos." (tradução nossa). Taking from the poor to give to the rich: the individualistic enforcement of social rights. Disponível em: $<$ http://www.enelsyn.gr/papers/w13/Paper\%20by\%20Prof.\%20Virgilio\%20Afonso\%20da\%20Silva.pdf >. Acesso em 10.11.2011.p. 6.

${ }^{76}$ HAMILTON, Alexander; MADISON, James; JAY, John. op. cit.
} 
Outrossim, não será muito produtivo estudar Brown averiguando a adequação da decisão ao verdadeiro conteúdo da equal protection clause, já que pouco se conseguirá construir abstratamente acerca de um conceito de igualdade universalmente aplicável. Não se pode negar que comumente as leis têm natureza discriminatória, sem que isso as caracterize como infratoras da isonomia. ${ }^{77}$ Será mais adequada, portanto, uma pesquisa das motivações tópicas que levaram às distinções legislativas e interpretativas em cada caso analisado.

Isso não quer dizer que os Federalists Papers e a equal protection clause não tenham papel importante na análise de Brown, mas os estudos não podem ficar a eles restritos, tampouco asseverar que ali reside o único locus acadêmico de investigação.

Sendo assim, optamos por não realizar um estudo teórico-digressivo ou dogmático acerca do ativismo judicial e seus temas correlatos (democracia, constitucionalismo, separação de poderes, interpretação das leis, etc.), preferindo dar ênfase ao aspecto empírico da atuação dos órgãos judiciários supremos no Brasil e nos Estados Unidos da América.

Essa é uma visão notadamente multidisciplinar que dialoga com as ciências políticas, tendo em vista que o ativismo não só lida com a eventual violação de uma norma jurídica ou a interpretação equivocada de uma lei, mas também tem profundo impacto econômico, social e nos Poderes instituídos em uma nação, alterando a vida de milhares ou milhões de pessoas.

Trata-se de um enfoque que tem pouca atenção na doutrina jurídica nacional, mas que está amplamente presente nas obras estadunidenses, em que as ciências políticas exercem um papel importante (ou até preponderante) nos estudos do ativismo.

Não queremos com isso afastar os fundamentos teóricos ou abandonar a visão normativa, posto que estarão presentes no trabalho. Apenas buscamos fornecer novas luzes sobre um aspecto do ativismo que consideramos de vital importância, mas que parece estar na penumbra.

\footnotetext{
${ }^{77}$ Neste sentido, por exemplo, a lei que determina o voto obrigatório a partir de dezoito anos está a discriminar aqueles que têm mais de dezoito daqueles que têm menos de dezoito anos. A adequação dessa medida com base no direito à igualdade não pode ser feita num raciocínio puramente formalista, posto que exigirá o julgamento de inconstitucionalidade desta lei e de todas as demais que apresentarem qualquer traço de discriminação, como a idade mínima para dirigir, para beber, se emancipar civilmente, etc. Sendo assim, existem motivações que justificam ou não a existência de determinadas discriminações, o que somente pode ser feito sob um viés tópico, haja vista que as razões da discriminação quanto à idade para dirigir não é mesma que para ser candidato a vereador, por exemplo.
} 
1.5 Conclusões preliminares

Ao final deste primeiro capítulo, podemos concluir que:

I - a construção de um conceito rigoroso e metodologicamente orientado deve satisfazer os requisitos quanto ao seu conteúdo, delimitação e identificação, de modo que seja possível conhecer as propriedades e características do termo ou expressão investigados, assim como apontar os objetos materiais ou imateriais que estão por ele abrangidos;

II - para os fins de nosso estudo, jurisdição constitucional é a competência atribuida positivamente ao órgão judiciário supremo de um país;

III - os conceitos de ativismo judiciário (ou judicial) presentes na doutrina não satisfazem os requisitos por nós elencados, tendo em vista seu conteúdo controverso e a impossibilidade de se identificarem as decisões judiciais ativistas com precisão. Empregaremos o termo, portanto, para designar uma concepção difusa de exercício ilegítimo do poder judicial, em que o juiz toma decisões com base em suas conviç̧ões e ideologia pessoais, em detrimento dos termos da lei e da Constituição.

IV - afastaremos uma concepção puramente dogmática de ativismo, consubstanciada na adoção prévia de verdades teóricas abstratas e irrefutáveis, para imprimir uma visão multidisciplinar de ativismo em sua relação dialética entre teoria e prática, verificando empiricamente a atuação dos órgãos judiciários supremos do Brasil e dos EUA e sua ressonância tanto na seara do direito constitucional, como na vida política, social e econômica de um país. 


\section{CAPÍTULO 2 - ANÁLISE COMPARATIVA ENTRE O SUPREMO TRIBUNAL FEDERAL BRASILEIRO E A SUPREMA CORTE ESTADUNIDENSE}

2.1 A origem histórica dos órgãos judiciários supremos do Brasil e dos Estados Unidos da América

A história da Suprema Corte e a do Supremo Tribunal Federal tiveram rumos diversos desde a sua criação $^{78}$ nos EUA e no Brasil, respectivamente. A primeira é marcada pela estabilidade e amadurecimento institucional, em virtude da consistente manutenção de sua Constituição há mais de dois séculos. Em contrapartida, a instabilidade política brasileira fez com que o STF tivesse denominações e papéis díspares na organização dos poderes nas 7 (sete) Constituições já estabelecidas desde a independência nacional, impossibilitando uma construção institucional mais sólida.

Examinaremos brevemente a origem de cada um dos órgãos judiciário citados, iniciando pela Suprema Corte, de modo a inserirmos uma perspectiva histórica na presente dissertação e fundamentar determinadas concepções até hoje presentes.

A Suprema Corte dos Estados Unidos da América foi criada pela Constituição de $1787^{79}$, que, em seu terceiro artigo, primeira seção, previu que o Poder Judiciário deve estar alicerçado em uma Corte Suprema e em cortes inferiores estabelecidas pelo Congresso, sendo esta a chamada vesting clause.

ARTICLE III.

SECTION 1. The judicial Power of the United States, shall be vested in one supreme Court, and in such inferior Courts as the Congress may from time to time ordain and establish. $[\ldots] .^{80}$

\footnotetext{
${ }^{78}$ A origem da criação do órgão judiciário supremo no Brasil não é precisa, não apenas em virtude das diversas Constituições de diferentes matizes que foram promulgadas ou outorgadas desde a independência de 1822, mas também pela existência anterior da Casa de Suplicação, que exercia função similar, porém com competência e forma de composição distintas.

${ }^{79} \mathrm{O}$ ano não é exato, pois a Constituição foi ratificada pelos Estados-membros em anos diferentes, sendo este apenas um referencial.

80 “O Poder Judicial dos Estados Unidos será revestido em uma Corte Suprema e em Cortes inferiores que o Congresso estabelecerá de tempos em tempos." (tradução nossa)
} 
Com a promulgação do Judiciary Act de 1789, o então Presidente George Washington foi indicou todos os 6 (seis) membros da Corte, cuja primeira sessão foi presidida pelo chief justice John Jay, um dos notórios founding fathers.

Em seus primeiros anos, a Corte não gozava de muito prestígio, e suas atribuições eram muito desgastantes. Uma das funções dos justices era percorrer todo o país julgando casos dos Tribunais estaduais, com vistas à uniformizar a interpretação da Constituição em âmbito nacional. Isto ficou conhecido como circuit riding, em virtude da divisão jurisdicional federal do país em treze circuits.

Essa atribuição se mantém até os dias de hoje, porém é preciso considerar que, no final do século XVIII e início do século XIX, as condições de deslocamento eram ruins, haja vista o meio de transporte e as estradas da época. Como resultado, os justices passassem extenuantes meses viajando para julgar poucos casos e comprometiam sua saúde, já agravada pelo fato da maioria contar com idade avançada.

Essas circunstâncias fizeram com que John Jay logo deixasse a Corte para ser governador de Nova Iorque, sendo que os outros dois chief justices que lhe sucederam também não permaneceram muito tempo no cargo.

Foi somente com a nomeação de John Marshall para chief justice, em 1801, e sua presidência por trinta e quatro anos que a Corte se consolidou e se transformou em um dos principais pilares do sistema político estadunidense. Conforme se verá mais adiante, a construção da doutrina do judicial review em Marbury v. Madison em 1803 assentou o poder da Corte em rever a legislação do congresso e anulá-la quando em desconformidade com a Constituição, o que lhe conferiu o papel de último de aprovador dos atos dos Poderes Legislativo e Executivo.

Essa posição proeminente da Corte não foi aceita prontamente pelos demais Poderes, o que acarretou anos de embates e manobras políticas até a sua consolidação. Sua própria jurisprudência teve momentos de aparente retrocesso e contradições doutrinárias com vistas a sua autopreservação, como foi o caso de Marbury e Stuart v. Laird, que será analisado mais adiante no subcapítulo acerca do judicial review.

Outro importante momento de solidificação da Corte foi a tentativa de impeachment de Samuel Chase, figura relativamente frágil que permitiria abrir precedente para um futuro processo contra Marshall, o verdadeiro alvo de Thomas Jefferson. O embate entre Marshall e Jefferson era notório, que o primeiro afrontava os interesses do Executivo e consolidava a força do Poder Judicial em prol da ideologia do partido oposicionista. 
Samuel Chase teve votação favorável ao impeachment na House of Representatives, o que gerou sua renúncia ao cargo. Tempos depois, foi absolvido pelo Senado.

A aparente derrota de Chase, todavia, não foi em vão. A partir dela, formou-se o entendimento de que o Poder Judiciário deve ser independente e que a discordância legislativa com as decisões judiciais não é causa para impeachment ${ }^{81}$, o que veio a fortalecer ainda mais a posição da Corte.

Desde a assinatura e ratificação da Constituição estadunidense, não houve modificações normativas substanciais na organização institucional da Corte, tendo sido mantidos desde então a forma de composição de seus membros, a irredutibilidade de vencimentos e o mandato vitalício. Apenas foram alterados os números de justices e a extensão de sua jurisdição.

A trajetória da Corte, portanto, tem sido marcada pela estabilidade constitucional e amadurecimento institucional do órgão, o que não quer dizer que não houve períodos de tensões e rispidez com os demais Poderes.

O mesmo não se pode dizer do Brasil, onde as mudanças políticas históricas têm alterado significativamente o Tribunal Supremo.

Após a independência brasileira em 07 de setembro de 1822, a Constituição Politica do Imperio do Brazil de 1824, em seu art. $163^{82}$, previu a criação do Supremo Tribunal de Justiça, que somente veio a ser efetivada com a Lei de 18 de setembro de 1828, sancionada pelo Imperador D. Pedro I.

O novo órgão de cúpula do judiciário deveria substituir a antiga Casa de Suplicação do Brasil, modelo colonial de inspiração portuguesa. A competência do Supremo Tribunal de Justiça, nos termos do art. 164 da Carga Magna ${ }^{83}$, estaria restrita ao recurso de revista, ao julgamento de conflitos de jurisdição e ações penais contra ocupantes dos cargos mais elevados da Nação.

\footnotetext{
${ }^{81}$ PFANDER, James E. Principles of federal jurisdiction. 2. ed. Sine loco: West, 2011. p. 7

${ }^{82}$ Art. 163. Na Capital do Imperio, além da Relação, que deve existir, assim como nas demais Provincias, haverá tambem um Tribunal com a denominação de - Supremo Tribunal de Justiça - composto de Juizes Letrados, tirados das Relações por suas antiguidades; e serão condecorados com o Titulo do Conselho. Na primeira organisação poderão ser empregados neste Tribunal os Ministros daquelles, que se houverem de abolir.

${ }^{83}$ Art. 164. A este Tribunal Compete:

I. Conceder, ou denegar Revistas nas Causas, e pela maneira, que a Lei determinar.

II. Conhecer dos delictos, e erros do Officio, que commetterem os seus Ministros, os das Relações, os Empregados no Corpo Diplomatico, e os Presidentes das Provincias.

III. Conhecer, e decidir sobre os conflictos de jurisdição, e competencia das Relações Provinciaes.
} 
Com a proclamação da República em 1889 e a instalação do Governo Provisório, o General Deodoro da Fonseca reorganizou a jurisdição federal por meio do Decreto 848 de 1890, que alterou o nome do Supremo Tribunal de Justiça para Supremo Tribunal Federal.

A definitiva normatização republicana veio poucos anos mais tarde, com a promulgação da Constituição da República dos Estados Unidos do Brasil de 1891, de larga influência estadunidense. De acordo com a nova Carta, o Supremo Tribunal Federal deveria ter competências originais e recursais ${ }^{84}$, podendo o Legislativo dispor sobre a organização da jurisdição federal inferior. ${ }^{85}$

O órgão deveria ser composto por quinze ministros, indicados pelo Presidente e aprovados pelo Senado ${ }^{86}$, cujo mandato era vitalício e sem limites etários. Restou também positivado o controle difuso de constitucionalidade das leis ${ }^{87}$, que era defendido em solo nacional por ilustres juristas, como Ruy Barbosa.

Esse modelo não teve alterações significativas mesmo com a Revolução de 1930, que deu fim à República Velha e estabeleceu uma nova ordem constitucional em 1934.

${ }^{84}$ Art 59 - Ao Supremo Tribunal Federal compete:

I - processar e julgar originária e privativamente:

a) o Presidente da República nos crimes comuns, e os Ministros de Estado nos casos do art. 52;

b) os Ministros Diplomáticos, nos crimes comuns e nos de responsabilidade;

c) as causas e conflitos entre a União e os Estados, ou entre estes uns com os outros;

d) os litígios e as reclamações entre nações estrangeiras e a União ou os Estados;

e) os conflitos dos Juízes ou Tribunais Federais entre si, ou entre estes e os dos Estados, assim como os dos Juízes e Tribunais de um Estado com Juízes e Tribunais de outro Estado.

II - julgar, em grau de recurso, as questões resolvidas pelos Juízes e Tribunais Federais, assim como as de que tratam o presente artigo, $\S 1^{\circ}$, e o art. 60 ;

III - rever os processos, findos, nos termos do art. 81.

$\S 1^{\circ}$ - Das sentenças das Justiças dos Estados, em última instância, haverá recurso para o Supremo Tribunal Federal:

a) quando se questionar sobre a validade, ou a aplicação de tratados e leis federais, e a decisão do Tribunal do Estado for contra ela;

b) quando se contestar a validade de leis ou de atos dos Governos dos Estados em face da Constituição, ou das leis federais, e a decisão do Tribunal do Estado considerar válidos esses atos, ou essas leis impugnadas.

$\S 2^{\circ}$ - Nos casos em que houver de aplicar leis dos Estados, a Justiça Federal consultará a jurisprudência dos Tribunais locais, e vice-versa, as Justiças dos Estados consultarão a jurisprudência dos Tribunais Federais, quando houverem de interpretar leis da União.

Art 81 - Os processos findos, em matéria crime, poderão ser revistos a qualquer tempo, em beneficio dos condenados, pelo Supremo Tribunal Federal, para reformar ou confirmar a sentença.

${ }^{85}$ Art 55 - O Poder Judiciário, da União terá por órgãos um Supremo Tribunal Federal, com sede na Capital da República e tantos Juízes e Tribunais Federais, distribuídos pelo País, quantos o Congresso criar.

${ }^{86}$ Art 56 - O Supremo Tribunal Federal compor-se-á de quinze Juízes, nomeados na forma do art. 48, nº 12, dentre os cidadãos de notável saber e reputação, elegíveis para o Senado.

${ }^{87}$ Art. 59 - Ao Supremo Tribunal Federal compete:

(...)

III- rever os processos, findos, nos termos do art. 81.

$\S 1$ Das sentenças das Justiças dos Estados, em última instância, haverá recurso para o Supremo Tribunal Federal:

a) quando se questionar sobre a validade, ou a aplicação de tratados e leis federais, e a decisão do Tribunal do Estado for contra ela;

b) quando se contestar a validade de leis ou de atos dos Governos dos Estados em face da Constituição, ou das leis federais, e a decisão do Tribunal do Estado considerar válidos esses atos, ou essas leis impugnadas. 
Em linhas gerais, foram mantidas as hipóteses de competência da Corte em seu art. 76, com a adição da vedação do conhecimento das questões políticas ${ }^{88}$, por influência, novamente, dos Estados Unidos, onde floresceu a political question doctrine, segundo a qual as Cortes deveriam ficar adstritas às questões jurídicas, não podendo ingressar no mérito político das leis.

O nome do órgão mudou para Corte Suprema e foi reduzido seu número de Ministros de quinze para onze, com a possibilidade de aumento por $1 \mathrm{ei}^{89}$. O preenchimento do cargo manteve-se vinculado à indicação presidencial com aprovação senatorial ${ }^{90}$.

A curta vigência da Constituição de 1934 teve fim com o golpe de 1937 e a imposição da nova Carta Constitucional, a Polaca, que deveria ser aprovada em plebiscito que nunca veio a ocorrer. Outrossim, pendente restou a instalação do Congresso, viabilizando um reinado político do Executivo Federal.

O cunho ditatorial do novo Estado significou um grande retrocesso na história da Corte, cuja independência e imparcialidade estavam em grande parte comprometidas. Ilustrativamente, o art. 96, parágrafo único, da Carta $^{91}$ previa a possibilidade de reversão das decisões de inconstitucionalidade da Corte pelo Parlamento, cuja inexistência era suprida pela normatização do Executivo. Apesar do quadro desfavorável, Gilmar Mendes $^{92}$ cita que o Supremo Tribunal Federal ainda teve disposição para julgar a inconstitucionalidade de uma lei que, posteriormente, acabou sendo revalidada por meio de decreto-lei.

Com o fim do período ditatorial e a promulgação da Constituição dos Estados Unidos do Brasil de 1946, foi retomada a independência do Supremo Tribunal Federal

\footnotetext{
${ }^{88}$ Art 68 - É vedado ao Poder Judiciário conhecer de questões exclusivamente políticas.

${ }^{89}$ Art 73 - A Corte Suprema, com sede na Capital da República e jurisdição em todo o território nacional, compõe-se de onze Ministros.

$\S 1^{\circ}$ - Sob proposta da Corte Suprema, pode o número de Ministros ser elevado por lei até dezesseis, e, em qualquer caso, é irredutível.

${ }^{90}$ Art 74 - Os Ministros da Corte Suprema serão nomeados pelo Presidente da República, com aprovação do Senado Federal, dentre brasileiros natos de notável saber jurídico e reputação ilibada alistados eleitores, não devendo ter, salvo os magistrados, menos de 35, nem mais de 65 anos de idade.

${ }^{91}$ Art 96 - Só por maioria absoluta de votos da totalidade dos seus Juízes poderão os Tribunais declarar a inconstitucionalidade de lei ou de ato do Presidente da República.

Parágrafo único - No caso de ser declarada a inconstitucionalidade de uma lei que, a juízo do Presidente da República, seja necessária ao bem-estar do povo, à promoção ou defesa de interesse nacional de alta monta, poderá o Presidente da República submetê-la novamente ao exame do Parlamento: se este a confirmar por dois terços de votos em cada uma das Câmaras, ficará sem efeito a decisão do Tribunal.

${ }^{92}$ MENDES, Gilmar Ferreira; COELHO, Inocencio Martires e BRANCO, Paulo Gustavo Gonet. Curso de direito constitucional. $4^{\mathrm{a}}$ ed. São Paulo: Saraiva, 2009. p. 985.
} 
como órgão de cúpula do Judiciário, integrado por onze Ministros ${ }^{93}$ de, no mínimo, trinta e cinco anos de idade, de notável saber jurídico e reputação ilibada. Todos deveriam ser nomeados pelo Presidente, condicionado à aprovação do Senado. ${ }^{94}$

As competências originais e recursais clássicas foram retomadas, sendo o período marcado pela consagração da representação interventiva em face de ato inconstitucional de violação de princípios sensíveis ${ }^{95}$, um dos pilares da construção nacional do controle abstrato de constitucionalidade

A trajetória democrática recém-estabelecida logo teria um novo revés com o golpe militar de 1964 e a edição do Ato Institucional n. 1 do mesmo ano, que não revogou a Carta de 1946, mas modificou-a significativamente.

No ano seguinte, o Ato Institucional n. 2 mudou o número de Ministros do STF de onze para dezesseis e alterou sensivelmente a função do órgão, determinando a exclusão de apreciação judicial de diversos temas. ${ }^{96}$ Em 1965, a Emenda Constitucional n. 16 criou formalmente o controle direto de constitucionalidade, mas com nítidos propósitos centralizadores, de modo que o Executivo federal pudesse ter maior domínio das questões de constitucionalidade no seio do Poder Judiciário.

Com a promulgação da Constituição da República Federativa do Brasil de 1967, foi mantido o STF como órgão de cúpula do Judiciário com dezesseis ministros (art. 113), o que somente foi alterado pelo Ato Institucional n. 6, de 1969, que o reduziu para onze.

\footnotetext{
${ }^{93}$ Art 98 - O Supremo Tribunal Federal, com sede na Capital da República e jurisdição em todo o território nacional, compor-se-á de onze Ministros. Esse número, mediante proposta do próprio Tribunal, poderá ser elevado por lei.

${ }^{94}$ Art 99 - Os Ministros do Supremo Tribunal Federal serão nomeados pelo Presidente da República, depois de aprovada a escolha pelo Senado Federal, dentre brasileiros (art. 129, $\mathrm{n}^{\text {o s }}$ I e II), maiores de trinta e cinco anos, de notável saber jurídico e reputação ilibada.

${ }^{95}$ Art. 7 - O Governo Federal não intervirá nos Estados salvo para:

(...)

VII - assegurar a observância dos seguintes princípios:

a) forma republicana representativa;

b) independência e harmonia dos Poderes;

c) temporariedade das funções eletivas, limitada a duração destas à das funções federais correspondentes;

d) proibição da reeleição de Governadores e Prefeitos, para o período imediato;'

e) autonomia municipal;

f) prestação de contas da Administração;

g) garantias do Poder Judiciário.

Art $8^{\circ}$ - A intervenção será decretada por lei federal nos casos dos $\mathrm{n}^{\mathrm{o}} \mathrm{\text {VI }}$ e VII do artigo anterior.

Parágrafo único - No caso do $\mathrm{n}^{\circ}$ VII, o ato argüido de inconstitucionalidade será submetido pelo ProcuradorGeral da República ao exame do Supremo Tribunal Federal, e, se este a declarar, será decretada a intervenção.

${ }^{96}$ Art. 19 - Ficam excluídos da apreciação judicial:

I - os atos praticados pelo Comando Supremo da Revolução e pelo Governo federal, com fundamento no Ato Institucional de 9 de abril de 1964, no presente Ato Institucional e nos atos complementares deste;

II - as resoluções das Assembléias Legislativas e Câmara de Vereadores que hajam cassado mandatos eletivos ou declarado o impedimento de Governadores, Deputados, Prefeitos ou Vereadores, a partir de 31 de março de 1964, até a promulgação deste Ato.
} 
O já solidificado processo de seleção dos membros foi mantido, assim como as representações interventivas e de inconstitucionalidade. ${ }^{97}$ A despeito de sua extensa competência $^{98}$, houve uma diminuição do papel político do Tribunal dessa época em razão do regime militar e o uso restrito do controle de constitucionalidade, cuja legitimidade de propositura era exclusiva do Procurador Geral da República.

${ }^{97}$ Art. 113 - O Supremo Tribunal Federal, com sede na Capital da União e jurisdição em todo o território nacional, compõe-se de 11 (onze) Ministros. (Redação dada pelo Ato Institucional n ${ }^{\circ} 6$, de 1969)

$\S 1^{\circ}$ - Os Ministros serão nomeados pelo Presidente da República, depois de aprovada a escolha pelo Senado Federal, dentre brasileiros natos, maiores de trinta e cinco anos, de notável saber jurídico e reputação ilibada. (Redação dada pelo Ato Institucional n ${ }^{\circ} 6$, de 1969)

98 Art 114 - Compete ao Supremo Tribunal Federal:

I - processar e julgar originariamente:

a) nos crimes comuns, o Presidente da República, os seus próprios Ministros e o Procurador-Geral da República;

b) nos crimes comuns e de responsabilidade, os Ministros de Estado, ressalvado, o disposto no final do art. 88, os Juizes Federais, os Juízes do Trabalho e os membros dos Tribunais Superiores da União, dos Tribunais Regionais do Trabalho, dos Tribunais de Justiça dos Estados, do Distrito Federal e dos Territórios, os Ministros dos Tribunais de Contas, da União, dos Estados e do Distrito Federal, e os Chefes de Missão Diplomática de caráter permanente;

c) os litígios entre Estilos estrangeiros, ou organismos internacionais e a União, os Estados, o Distrito Federal e os Municípios;

d) as causas e conflitos entre a União e os Estados, ou Territórios, ou entre uns e outros;

e) os conflitos de jurisdição entre Juizes ou Tribunais federais de categorias diversas; entre quaisquer Juizes ou Tribunais federais e os dos Estados; entre, os Juizes federais subordinados a Tribunais diferentes; entre Juízes ou Tribunais de Estados diversos, inclusive os do Distrito Federal e Territórios;

f) os conflitos de atribuições entre autoridade administrativa e judiciária da União ou entre autoridade judiciária de um Estado e a administrativa de outro, ou do Distrito Federal e dos Territórios, ou entre estes e as da União;

g) a extradição requisitada por Estado estrangeiro e a homologação das sentenças estrangeiras;

h) o habeas corpus, quando o coator ou paciente for Tribunal, funcionário ou autoridade, cujos atos estejam diretamente sujeitos à jurisdição do Supremo Tribunal Federal ou se tratar de crime sujeito à essa mesma jurisdição em única instância, bem como se houver perigo de se consumar a violência antes que outro Juiz ou Tribunal possa conhecer do pedido;

i) os mandados de segurança contra ato do Presidente da República, das Mesas da Câmara e do Senado, do Presidente do Supremo Tribunal Federal e do Tribunal de Contas da União;

j) a declaração de suspensão de direitos políticos, lia forma do art. 151;

1) a representação do Procurador - Geral da República, por inconstitucionalidade de lei ou ato normativo federal ou estadual;

m) as revisões criminais e as ações rescisórias de seus julgados;

n) a execução das sentenças, nas causas de sua competência originária, facultada a delegação de atos processuais;

II - julgar, em recurso ordinário: (Redação dada pelo Ato Institucional no 6, de 1969)

a) os habeas corpus decididos, em única ou última instância, pelos Tribunais locais ou federais, quando denegatória a decisão, não podendo o recurso ser substituído por pedido originário

b) as causas em que forem partes um Estado estrangeiro e pessoa domiciliada ou residente no País;

c) os casos previstos no art. $122, \S 2^{\circ}$;

III - julgar, mediante recurso extraordinário, as causas decididas, em única ou última instância, por outros Tribunais, quando a decisão recorrida: (Redação dada pelo Ato Institucional $\mathrm{n}^{\circ} 6$, de 1969)

a) contrariar dispositivo desta Constituição ou negar vigência a tratado ou lei federal;

b) declarar a inconstitucionalidade de tratado ou lei federal;

c) julgar válida lei ou ato do Governo local, contestado em face da Constituição ou de lei federal;

d) dar à lei federal interpretação divergente da que lhe haja dado outro Tribunal ou o próprio Supremo Tribunal Federal. 
Com o fim do regime militar e o processo de redemocratização do Brasil, foi promulgada a atual Constituição da República Federativa de 1988, que manteve algumas características tradicionais do Supremo Tribunal Federal, como sua forma de composição, o controle de constitucionalidade das leis e sua vasta competência recursal e originária.

O breve estudo histórico realizado nos mostra que a diversidade políticoinstitucional dos mais de dois séculos de independência brasileira não permitiu uma leitura histórica linear do Tribunal, cujas mudanças constitucionais abruptas e incisivas impediram sua consolidação nos mesmos moldes dos EUA.

Isto não quer dizer que alguns traços não tenham sido mantidos tradicionalmente entre nós, como é o caso do processo de seleção dos Ministros. O problema aqui, é que as rupturas entre regimes democráticos e autoritários não permitiram uma estabilização jurisprudencial e doutrinária que quase sempre se modificou junto com eles.

Deste modo, focaremos a presente dissertação nas Constituições brasileira e estadunidense em vigor, fazendo pontuais incursões históricas, cujos contextos serão prontamente revelados sempre que assim for necessário.

2.2 A competência do Supremo Tribunal Federal brasileiro e da Suprema Corte estadunidense

Tanto no Brasil quanto nos Estados Unidos da América, a questão da competência dos órgãos judiciários supremos é de vital importância para a efetivação dos compromissos assumidos na Carta Constitucional, funcionando as Cortes como o último recurso para a garantia das normas ali previstas, fiscalizando e sendo fiscalizada pelos demais Poderes (checks and balances).

Notadamente, a competência das Cortes reflete os limites de atuação judicial em um Estado, especialmente sobre os Poderes Executivo e Legislativo, modificando ou anulando seus atos, tanto na esfera concreta, e.g., suspendendo a licitação de uma obra, quanto na abstrata, e.g., anulando uma lei.

Saber exatamente quais são os limites das Cortes, ou seja, qual é precisamente a sua competência, resolveria em grande parte o problema do ativismo judicial, pois uma linha demarcatória poderia ser traçada e identificadas as decisões que a extrapolassem. Neste caso, tais julgamentos poderiam ser condenados com maior segurança, ao contrário 
do que ocorre atualmente, em que as decisões polêmicas levantam mais vozes dissonantes do que consensuais.

A hipótese de uma desaprovação majoritária calcada em fundamentos robustos e precisos fatalmente mitigaria a credibilidade e a legitimidade da decisão, o que causaria a perda de sua força e de sua executoriedade. No limite, os juízes poderiam ser responsabilizados e as decisões anuladas ou revertidas

Infelizmente, essa linha clara e absoluta de limite jurisdicional não existe, embora algumas áreas de competência tenham parâmetros mais bem delineados do que outras, seja em função do texto normativo ou por meio de interpretação jurisprudencial.

Não podemos esquecer que as Cortes não julgam casos ativistas e altamente complexos todos os dias, passando boa parte do ano analisando processos que não suscitam grandes controvérsias em âmbito nacional, ficando restritas à resolução do litígio inter partes.

Considerando, portanto, que nem toda atividade judicial da Corte está relacionada diretamente com o nosso tema proposto, optamos por fazer um recorte metodológico em prol de um estudo sintético e focado na questão do ativismo, posto que uma análise integral seria extenuante e de pouco proveito aos nossos objetivos.

Inclusive, trataremos com maior afinco da competência da Suprema Corte dos EUA, uma vez que nosso conhecimento sobre ela é mais limitado e há a necessidade de uma inserção mais profunda na common law e no modelo jurisdicional estadunidense para que o estudo comparado se torne viável.

No que tange ao estudo das competências do Supremo Tribunal Federal, acreditamos ser desnecessário aqui repetir as inúmeras doutrinas brasileiras que tratam exaustivamente - e com maior propriedade - sobre o tema, apenas a elas fazendo referência e assumindo um conhecimento prévio mínimo por parte do leitor.

Sendo assim, antes de mais nada, é necessária uma pequena imersão no sistema jurídico estadunidense, o que será feito no próximo subcapítulo. 
Como é de conhecimento comum, nos Estados Unidos da América vige o sistema da common law, ${ }^{99}$ caracterizada, principalmente, pela importância dos precedentes na conformação do Direito, agindo ora como instrumento secundário e interpretativo das normas vigentes, ora como fonte originária e criadora de normas, lato sensu.

Deve-se salientar que a common law não é simplesmente um sistema em que a decisão judicial tem peso significativo, em contraposição ao direito romanístico, no qual reina o império da lei. Essa leitura seria reducionista demais e não revelaria a realidade desses dois sistemas.

De fato, a common law é extremamente complexa, pois reúne diversos elementos que devem ser meticulosamente ponderados para se construir o direito.

Primeiramente, deve-se considerar que o raciocínio judicial empregado é tópico, ou seja, está direcionado para a resolução de um conflito real e determinado. Logo, o direito que ali nasce e rege a relação jurídica está intrinsecamente associado ao conjunto fático litigioso.

Isto poderia levar à conclusão de que a decisão opera somente efeitos inter partes, o que não é exatamente apurado. Um precedent não é apenas a resolução de um caso específico, mas também uma importante diretriz de como as Cortes enxergam o tipo de litígio em tela, transparecendo como poderá julgar questões similares.

Isso conduz a um raciocínio fundamental na common law, em que os casos concretos e intimamente ligados ao seu contexto fático projetam uma imagem de proposições gerais abstratas nos moldes de uma norma jurídica. O que não quer dizer que a norma exista efetivamente, pois é somente uma projeção do precedent, que pode ou não encontrar ressonância em outro caso similar, a depender do juízo que o Tribunal realizar sobre o conjunto fático desse outro litígio.

Mais complexo se torna esse modo de enxergar o Direito quando é inserida uma norma positivada para integrar o juízo final da decisão judicial, uma vez que deverão ser ponderados os elementos fáticos, as projeções de decisões anteriores e o enunciado abstrato e generalista.

99 Para um estudo conciso e denso da common law e sua distinção do sistema romanístico, ver FAIRGRIEVE, Duncan; WATT, Horatia Muir. Common law et tradition civiliste. 1. ed. Paris: Presses Universitaire de France, 2006. 
Para complicar ainda mais, bastar lembrar que a common law é uma construção histórica de direito pelos Tribunais, em que os precedents permanecem vivos durante mais de séculos de atividade judicial. Não há uma disposição cultural dos juízes para superar o entendimento de um precedent, ainda que realizado há mais de um século e sob leis e contextos sociais diversos. A força do precedent é também a força do Judiciário, e por isso os juízes tentam sempre realizar um juízo de distinction entre os litígios, de modo que seja possível afastar a decisão de um precendent antigo a um caso recente, sem invalidar ou superar as ponderações daquele julgado, que subsiste amarrada aos fatos descritos naquele processo.

Essa complexidade da common law é de difícil compreensão, em um primeiro momento, para um jurista da civil law, acostumado a lógica dedutivista em que a norma reina absoluta e deve ser interpretada e aplicada em um caso concreto. Doutrina e jurisprudência não têm natureza normativa, apenas auxiliam na interpretação da lei e têm força argumentativa.

Todavia, é certo que nem sempre a common law conduz a resultados coerentes ou lógicos, não sendo raras as críticas dirigidas aos Tribunais quanto à inconsistência de seus julgados. O caso Brown, por exemplo, teria acabado com a segregação racial nos EUA, pondo fim à doutrina do separate but equal originada em Plessy v. Ferguson. Todavia, não é essa a leitura que se faz da opinion exarada em Brown, em que foi realizado um juízo de distinction entre Plessy - vinculado à constitucionalidade de uma lei estadual que previa locais e bancos separados para negros nos ônibus - e Brown, vinculado à segregação nas escolas públicas. Nesse caso, a Corte não superou Plessy, apenas asseverou que a doutrina do separate but equal não era aplicável no âmbito do direito educacional. A comunidade jurídica, entretanto, entendeu o recado da Corte, e a segregação racial na esfera jurídica estava com os dias contados.

Esse quadro de alta complexidade ainda conta com a questão da organização judiciária dúplice, ou seja, há duas esferas distintas de jurisdição, a estadual e a federal ${ }^{100}$, sendo que alguns temas são de competência exclusiva de uma delas, e outros concorrentes, isto é, podem ser julgados por qualquer uma das duas.

$\mathrm{Na}$ história dos EUA, a autonomia dos Estados membros sempre conflitou diretamente com a existência de uma Suprema Corte nacional e unificadora da interpretação das leis. Tendo em vista que os Estados-membros guardam parcela

\footnotetext{
${ }^{100}$ Ver a respeito a obra, DAVID, René. Os grandes sistemas do direito contemporâneo. São Paulo: Martins Fontes, 1998.
} 
significativa de competência legislativa e, portanto, há leis distintas entre os Estados, é natural que haja microcosmos jurisprudenciais em cada jurisdição estadual, cujos posicionamentos nos precedents podem estar em conflito entre as Cortes estaduais ou federais. Trata-se, inclusive, de uma questão estratégica dos litigantes entre levar um caso para uma corte estadual ou federal, quando o tema pode ser conhecido pelas duas.

Sob o ponto de vista dos Estados-membros, isso é reflexo de sua autonomia no pacto federativo, mas, para a União, isso gera inúmeras desigualdades de difícil compatibilização em termos de desenvolvimento de políticas públicas nacionais.

Além do mais, o movimento populacional e de atividade econômica varia significativamente em razão das leis de cada Estado, o que pode exigir a intervenção da União para não desequilibrar excessivamente o país.

Sendo assim, o tema dos limites da autonomia dos Estados e da centralização da União é extremamente sensível na história dos Estados Unidos, e passa também pela Suprema Corte, já que ela é o órgão judicial unificador por excelência.

Outro tema importante que deve ser conhecido antes de adentrarmos ao estudo comparado das competências da Corte brasileira e estadunidense é o da construção jurisprudencial da justiciability doctrine. Primeiramente, é preciso advertir que o termo doctrine empregado judicialmente nos Estados Unidos não pode ser traduzido simplesmente por doutrina, no sentido por nós utilizado de opinião ou visão de um acadêmico acerca de um tema. Na common law, uma doctrine reflete as diretrizes da Corte presentes em uma decisão judicial sobre determinado assunto.

Ao longo dos séculos, os Tribunais têm criado e desenvolvido em sua jurisprudência requisitos e condições para aferir se uma causa deve ou não ser conhecida e julgada por ele, o que entre nós é realizado pela codificação processual (ainda que algumas questões tenham discutível natureza de direito material).

São cinco as principais doctrines criadas pela Corte, às quais faremos breve menção.

A primeira delas é a prohibition against advisory opinions (ou ban on advisory opinions), por meio da qual a Suprema Corte determinou que o Poder Judiciário não pode emitir pareceres ou opinar sobre questões hipotéticas, desvinculadas de um conflito real entre duas ou mais partes. Trata-se de um mecanismo que veda o conhecimento de questões abstratas e fortalece a atuação da Corte na resolução de conflitos concretos.

Sua origem provém de uma consulta feita pelo então Presidente Thomas Jefferson à Suprema Corte, questionando-a por meio de uma carta sobre a constitucionalidade de 
determinadas condutas que o Executivo não estava seguro se poderia tomar ou não. Mais especificamente, Jefferson visava realizar transações comerciais com a Inglaterra e a França em um período em que elas estavam em guerra, sendo duvidoso se tal comércio era permitido pelas leis e tratados então vigentes.

Em resposta, o chief justice Marshall lamentou a impossibilidade de atender o pedido presidencial, afirmando, com elevada erudição, que a manifestação da Corte por meio de consultas ou qualquer outra forma especulativa e desvinculada de um litígio concreto, violaria sua atuação jurisdicional prevista na Constituição, além de influenciar ou até mesmo conformar a adoção de medidas pelo Executivo, que desnaturariam a essência da separação de Poderes.

Essa doutrina se solidificou ao longo dos anos, de modo que a Suprema Corte afirmou-se como um espaço de julgamento de disputas reais entre litigantes, não cabendo a ela emitir opiniões prévias sobre a constitucionalidade ou não de diplomas normativos e de eventuais condutas que podem ou não ser tomadas pelos órgãos governamentais.

Conforme se verá mais adiante, não é o mesmo que ocorre no Brasil, onde o controle de constitucionalidade abstrato visa justamente à manifestação do STF sobre a validade de determinada norma, a despeito da existência de um conflito fático sobre ela. No âmbito do Tribunal Superior Eleitoral, existe o mecanismo da consulta, em que os partidos podem apresentar dúvidas sobre a correta interpretação das leis, aliadas ou não a um hipotético caso imaginário. Isso tem gerado inúmeras controvérsias, porque a resposta do Tribunal, de um lado, gera segurança jurídica e previsibilidade aos atores políticos, mas, por outro lado, as consultas não são capazes de trazer à tona toda a gama complexa de fatos e normas que o tema suscita, o que levou o Tribunal a considerar como não vinculativas suas próprias opiniões exaradas em consultas, causando contradições e a insegurança que o próprio instituto visava evitar.

A ausência de perspectiva concreta da aplicação da lei foi justamente uma das maiores preocupações de Marshall ao consolidar o papel da Suprema Corte adstrito ao julgamento de conflitos reais, afastando-a de um diálogo institucional e especulativo com o Legislativo ${ }^{101}$, que poderia provocar uma sensível e perigosa aproximação entre os Poderes, que, na verdade, devem ser fiscais um do outro (check and balances).

\footnotetext{
${ }^{101}$ Há leis estaduais que permitem que o Judiciário local se manifeste sobre a constitucionalidade de leis pendentes de aprovação na Assembléia Legislativa. CHEMERINSKY, Erwin. Constitutional law: principles and policies. 3 ed. New York: Aspen, 2006. p. 53.
} 
Outras doutrinas foram criadas ao redor da prohibition against advisory opinions, no sentido de assegurar a existência de um conflito real de interesses nas ações interpostas na Suprema Corte. Algumas têm ligação imediata com ela, outras apenas remotas.

Resumidamente, são elas: i) o standing, que estabelece que o requerente deve provar que sofreu ou está na iminência de sofrer um dano, de forma que seja possível aferir o injury (dano), a causation (nexo causal) e a redressability (compensação); ii) a ripeness, que exige que a questão levada até a Suprema Corte esteja madura o suficiente para ser conhecida por ela, fazendo especial alusão ao prequestionamento e debate nas Cortes inferiores; e iii) a mootness, que exige que o conflito esteja "vivo" quando chegar a julgamento, não podendo os juízes se manifestar caso o conflito não mais exista. Isso pode ocorrer por diversas razões em que há a perda do objeto, como a conciliação, causas extintivas do direito, entre outros.

Por fim, e não menos importante, há a political question doctrine, criada para afastar as Cortes do conhecimento de questões políticas. Trata-se de uma ideia que remonta à Marbury v. Madison, onde ficou assentado que "Questions, in their nature political or which are by the constitution and laws, submitted to the executive can never be made in this court". ${ }^{102}$

Embora seja uma ideia relativamente consensual de que as Cortes não devem julgar as decisões políticas tomadas pelos poderes competentes dentro do âmbito de sua discricionariedade, ninguém conseguiu, até o momento, estabelecer critérios úteis e consistentes daquilo que é uma questão política, considerado o ordenamento jurídico como um todo. ${ }^{103}$

A natureza da Corte e do diploma que ela interpreta e aplica - a Constituição torna praticamente impossível a separação clara entre um tema que a Corte pode atuar e outro que compete à ponderação exclusiva do Executivo ou do Legislativo, sem que haja qualquer possibilidade de interferência do Poder Judiciário.

Se a Constituição deve reger a atuação de todos os Poderes, é contraditório pensar que determinados atos não podem ser fiscalizados, exceto se a própria Constituição assim determinar. Isto conduz ao paradoxo da visão sistemática da Constituição, em que um ato

\footnotetext{
102 "questões de natureza política ou que estão confiadas ao Executivo pela Constituição e pelas leis, não podem ser avaliadas nesta Corte" (tradução nossa). Marbury v. Madison, 5 U.S. (1 Cranch) 137 (1803)

${ }^{103}$ Alguns casos podem apresentar respostas mais fáceis quanto ao poder de discricionariedade ou não do poder político, a depender, principalmente, da linguagem empregada na norma. Por esta razão, Elival propõe um sistema de controle baseado no nível de abertura da norma jurídica, variando de controles judiciais fortes a fracos em sua obra "Ativismo Judicial" (op. cit.). Também Ely fala sobre níveis de abertura semântica das normas em ELY em "Democracy and Distrust" (op. cit.).
} 
pode ser totalmente discricionário em um primeiro momento, em razão da determinação de uma norma específica, mas, em um segundo momento, esse mesmo ato deve ser confrontado com o todo da Constituição, não podendo violar outras disposições, o que mitiga sensivelmente esta discricionariedade.

Esse limite de atuação das Cortes e dos Poderes Executivo e Legislativo está diretamente ligado ao ativismo, pois é justamente a ausência de linhas demarcatórias claras que coloca em conflito os poderes constituídos, levando 'a acusação de que o Judiciário sobrepôs sua vontade ilegitimamente sobre os demais.

Ciente de suas implicações, a Suprema Corte tentou buscar soluções para esse problema, tanto enxergando-o universalmente, ou seja, articulando critérios válidos para toda e qualquer questão de direito, quanto setorizadamente, estabelecendo diretrizes sobre casos e normas específicas.

Em Baker v. Carr, a Suprema Corte fez a sua mais audaciosa tentativa de formular uma doutrina sobre as questões políticas, estabelecendo parâmetros analíticos sobre ela. As críticas, porém, foram ferozes e não houve aceitação pela comunidade jurídica.

Em questões específicas, por sua vez, a Corte parece ter tido mais sucesso, como é o caso da construção jurisprudencial originada em Luther v. Borden, em que restou decidido que não é causa suficiente de justiciability a alegação de violação da republican form of government clause ${ }^{104}$, considerada como uma questão política.

Chemerinsky assegura que o caso Luther tem sido respeitado com consistência ao longo dos anos, sem que nenhuma decisão de um governo local tenha sido invalidada sob o fundamento da cláusula republicana. ${ }^{105}$ Todavia, o mesmo autor questiona a praticidade dessa doutrina, na medida em que o mesmo ato pode ser questionado sob diversos fundamentos, e, apesar de a Corte negá-lo em face da cláusula republicana, poderia conhecê-lo como uma violação a outros princípios, como o due process clause.

Há um certo artificialismo, portanto, quanto a essa doutrina no seio do Poder Judiciário, o que tem sido acompanhado pela divisão da comunidade jurídica

Os defensores da political question doctrine alegam, em suma, que: i) os Tribunais devem ter limites em uma sociedade democrática; ii) a legitimidade do Judiciário não é forte o bastante para ele tomar determinadas decisões polêmicas; iii) outros órgãos têm melhor know how e mais material humano para decidir sobre determinados temas, como

\footnotetext{
${ }^{104} \mathrm{O}$ artigo 4, seção 4 da Constituição reza que "The United States shall guarantee to every State in this Union a Republican form of government" (Os Estados Unidos devem garantir a todos os Estados uma forma republicana de governo) (tradução nossa)

${ }^{105}$ CHEMERINSKY, Erwin. p. 136.
} 
por exemplo, acordos comerciais internacionais; e iv) a Corte é suspeita para julgar algumas questões, como as leis que tratam de sua própria competência e instrumentos processuais.

Por outro lado, aqueles que são contrários à doutrina aduzem que: i) a corte deve concretizar a Constituição em sua integralidade (não há espaço onde ela não possa ser observada); ii) o Judiciário possui alta credibilidade nos poderes políticos e na sociedade advinda da qualidade de suas decisões; e iii) as Cortes devem ter deferência e respeito aos outros poderes, o que não significa abdicar de seu papel de fiscalização.

Conforme visto, a questão é árdua e não apresenta respostas fáceis. No Brasil, embora não haja um desenvolvimento mais específico da doutrina, ela já constou de regulamentação constitucional ${ }^{106}$, e hoje em dia é frequentemente associada ao estudo do ativismo. Dentre nós, parece haver consenso quanto à inconsistência teórica da doutrina das questões políticas, embora isso não tenha significado a inconsistência teórica das doutrinas ativistas, que se fundamentam em questões diversas, porém, correlatas.

Neste sentido, acreditamos que as limitações da political question doctrine parecem ser as mesmas do ativismo: ausência de distinções claras de matérias que cabem ou não ao Judiciário julgar, tomando como parâmetro normas ambíguas e vagas.

Por esta razão, concordamos com Chemerinski quando assevera que a political question doctrine apresenta duas faces, uma de cunho dogmático constitucional e outra de caráter mais flexível, prudencial. Segundo o autor,

The political question doctrine might be treated as constitutional if it is thought to be based on separation of powers or textual commitments to other branches of government. On the other hand, the doctrine is prudential if it reflects the Court's concerns about preserving judicial credibility and limiting the role of an unelected judiciary in a democratic society. ${ }^{107}$

Deste modo, apesar da ausência de critérios úteis e precisos para a aferição das questões políticas, ela ainda resiste como um espaço argumentativo sobre o adequado locus do Poder Judiciário nas sociedades democráticas.

\footnotetext{
${ }^{106} \mathrm{Na}$ Constituição de 1934 constava o seguinte dispositivo: art 68 - É vedado ao Poder Judiciário conhecer de questões exclusivamente políticas.

107 "A doutrina da questão política pode ser tratada como constitucional sob a perspectiva da separação dos poderes e compromissos expressos com os demais ramos do governo. Por outro lado, a doutrina é "prudencial" se ela refletir a preocupação da Corte em preservar sua credibilidade judicial e limitar o papel de um judiciário não eleito na sociedade democrática." (tradução nossa). CHEMERINSKY, Erwin, op. cit. p. 134.
} 
No próximo subcapítulo, veremos qual é esse lugar reservado aos órgãos judiciários supremos no Brasil e nos EUA, por meio do estudo de suas competências.

\subsubsection{Competência originária}

Tanto no Supremo Tribunal Federal quanto na Suprema Corte existem duas espécies de competência, a originária e a recursal. Neste momento, faremos um estudo da competência originária de ambas as Cortes sob um viés comparativo, reservando a questão do controle de constitucionalidade para um subcapítulo à parte.

No Brasil, conforme visto em nossa pesquisa histórica, a competência originária do Supremo Tribunal Federal sempre foi relativamente extensa, em razão das prerrogativas de foro de diversas autoridades públicas, seu papel como julgador dos conflitos de jurisdição interna, instância de resolução de litígios internacionais e órgão máximo recursal do sistema judiciário nacional.

Atualmente, sua competência vem descrita no art. 102, inciso I da Carta Magna, nos seguintes termos:

Art. 102. Compete ao Supremo Tribunal Federal, precipuamente, a guarda da Constituição, cabendo-lhe:

I - processar e julgar, originariamente:

a) a ação direta de inconstitucionalidade de lei ou ato normativo federal ou estadual e a ação declaratória de constitucionalidade de lei ou ato normativo federal;

b) nas infrações penais comuns, o Presidente da República, o VicePresidente, os membros do Congresso Nacional, seus próprios Ministros e o Procurador-Geral da República;

c) nas infrações penais comuns e nos crimes de responsabilidade, os Ministros de Estado e os Comandantes da Marinha, do Exército e da Aeronáutica, ressalvado o disposto no art. 52, I, os membros dos Tribunais Superiores, os do Tribunal de Contas da União e os chefes de missão diplomática de caráter permanente;

d) o "habeas-corpus", sendo paciente qualquer das pessoas referidas nas alíneas anteriores; o mandado de segurança e o "habeas-data" contra atos do Presidente da República, das Mesas da Câmara dos Deputados e do Senado Federal, do Tribunal de Contas da União, do Procurador-Geral da República e do próprio Supremo Tribunal Federal;

e) o litígio entre Estado estrangeiro ou organismo internacional e a União, o Estado, o Distrito Federal ou o Território;

f) as causas e os conflitos entre a União e os Estados, a União e o Distrito Federal, ou entre uns e outros, inclusive as respectivas entidades da administração indireta; 
g) a extradição solicitada por Estado estrangeiro;

h) (revogado)

i) o habeas corpus, quando o coator for Tribunal Superior ou quando o coator ou o paciente for autoridade ou funcionário cujos atos estejam sujeitos diretamente à jurisdição do Supremo Tribunal Federal, ou se trate de crime sujeito à mesma jurisdição em uma única instância;

j) a revisão criminal e a ação rescisória de seus julgados;

1) a reclamação para a preservação de sua competência e garantia da autoridade de suas decisões;

m) a execução de sentença nas causas de sua competência originária, facultada a delegação de atribuições para a prática de atos processuais;

n) a ação em que todos os membros da magistratura sejam direta ou indiretamente interessados, e aquela em que mais da metade dos membros do tribunal de origem estejam impedidos ou sejam direta ou indiretamente interessados;

o) os conflitos de competência entre o Superior Tribunal de Justiça e quaisquer tribunais, entre Tribunais Superiores, ou entre estes e qualquer outro tribunal;

p) o pedido de medida cautelar das ações diretas de inconstitucionalidade;

q) o mandado de injunção, quando a elaboração da norma regulamentadora for atribuição do Presidente da República, do Congresso Nacional, da Câmara dos Deputados, do Senado Federal, das Mesas de uma dessas Casas Legislativas, do Tribunal de Contas da União, de um dos Tribunais Superiores, ou do próprio Supremo Tribunal Federal;

r) as ações contra o Conselho Nacional de Justiça e contra o Conselho Nacional do Ministério Público;

Nota-se que não só houve a manutenção das competências tradicionais já descritas, como também sua ampliação por meio de ações e institutos criados pela Constituição de 1988 ou pelas Emendas que a sucederam, como é o caso da Ação Declaratória de Constitucionalidade (EC 3/43) e as ações contra o Conselho Nacional de Justiça e contra o Conselho Nacional do Ministério Público (EC 45/04).

O Supremo Tribunal Federal brasileiro, portanto, desempenha um importante papel próprio de um Tribunal Constitucional e Recursal, além de instância primeira e única de julgamento de diversos sujeitos e matérias, como é caso das competências criminais por prerrogativa de foro, da intervenção federal e dos litígios internacionais de Estados estrangeiros contra a União.

Não iremos aqui fazer o estudo detalhado de cada uma destas hipóteses, mesmo porque, como já asseverado, isso seria exaustivo e desnecessário para os fins do trabalho, havendo inúmeras doutrinas abalizadas sobre o tema que. ${ }^{108}$

\footnotetext{
${ }^{108}$ MORAES, Alexandre de. Direito constitucional. 22 $2^{\mathrm{a}}$ ed. São Paulo: Atlas, 2007; FERREIRA FILHO, Manoel Gonçalves. Curso de direito constitucional. 33 a ed. São Paulo: Saraiva, 2007; MENDES, Gilmar Ferreira; COELHO, Inocencio Martires e BRANCO, Paulo Gustavo Gonet. Curso de direito
} 
O que é importante averiguar é se a competência do Supremo Tribunal Federal e da Suprema Corte se assemelham ou não, e em que medida as igualdades ou distinções podem influenciar no fenômeno do ativismo aqui e lá.

Quanto à jurisdição originária da Suprema Corte, ela está descrita na Constituição dos EUA, em seu artigo 3, seção 2, cláusula 2:

2 In all Cases affecting Ambassadors, other public Ministers and Consuls, and those in which a State shall be Party, the supreme Court shall have original Jurisdiction. In all the other Cases before mentioned, the supreme Court shall have appellate Jurisdiction, both as to Law and Fact, with such Exceptions, and under such Regulations as the Congress shall make. ${ }^{109}$

A leitura do artigo nos revela uma competência bem restrita e vinculada às partes processuais de um litígio, notadamente, figuras de representação externa e os Estadosmembros. Podemos, em um primeiro momento, concluir que a competência da Suprema Corte é bem mais limitada do que a do STF, o que nos indica uma extensão menor do poder de julgamento e de interferência da Corte, reduzindo suas possibilidades de exercício do ativismo.

Todavia, em razão das características da common law, é necessário verificar como esse texto normativo tem sido interpretado no seio dos precedents para alcançar uma conclusão definitiva.

Isto porque, seria de se supor que toda ação que tivesse como sujeito processual uma das figuras mencionadas, deveria ser interposta com exclusividade perante a Suprema Corte, onde obrigatoriamente ela seria julgada. Todavia, os precedents lhe deram uma conformação totalmente distinta da narrada, até certo ponto, contraditória com o texto literal.

A primeira decisão significativa sobre a competência originária da Corte foi proferida no célebre caso Marbury v. Madison em 1803, em que o juiz John Marshall entendeu que o rol de competências originárias previsto na Constituição era exaustivo e que, portanto, nenhuma lei federal poderia ampliar as hipóteses ali previstas. Deste modo, julgou inconstitucional o dispositivo do Judiciary Act de 1789, que facultava a concessão

constitucional. $4^{\mathrm{a}}$ ed. São Paulo: Saraiva, 2009; SILVA, José Afonso da. Curso de direito constitucional. $19^{a}$ ed. São Paulo: Malheiros Editores, 2001.

109 "Em todos os litígios envolvendo Embaixadores, ministros e cônsules e naqueles em que um Estado será parte, a Suprema Corte terá jurisdição originária. Nos outros litígios antes mencionados [se refere à seção anterior], a Suprema Corte terá jurisdição recursal, tanto quanto ao direito e aos fatos, respeitadas as exceções, e de acordo com as regulamentações que o Congresso editará." (tradução nossa) 
do writ of mandamus pela Corte, frustrando as expectativas de Marbury em ter sua nomeação a juiz de paz entregue compulsoriamente por Madison.

Posteriormente, em 1821, o mesmo John Marshall julgaria o caso Cohens $v$. Virgina, em que ficou assentado que a competência originária não significava competência exclusiva da Suprema Corte, sendo possível que os litígios envolvendo diplomatas e Estados-membros fossem julgados por outros Tribunais, alcançando o órgão supremo pela via recursal.

Mais recentemente, em Ohio v. Wyandotte Chemicals (1971), a Suprema Corte decidiu que pode exercer juízo de discricionariedade no conhecimento de ações fundadas em sua competência originária, ou seja, ela pode decidir livremente se conhecerá da ação ou não. Trata-se de um expediente historicamente utilizado no juízo de admissibilidade em sede de competência recursal, que não possui regras e critérios pré-determinados e se expressa por meio do recurso chamado writ of certiorari, que será detalhado mais adiante.

Tanto o caso Cohens quanto Ohio parecem não respeitar fielmente o texto constitucional, na medida em que a ideia de competência originária está indissociavelmente ligada ao conhecimento primeiro da causa por determinado órgão judicial, não podendo ele delegar tal atribuição, tampouco negar seu julgamento. Se o órgão que deve conhecer a ação é o mais alto na hierarquia judicial e ele não aceita determinado litígio, quem então poderá fazê-lo se não há instância superior?

Nas palavras de Pfander $^{110}$, o posicionamento da Suprema Corte não tem sido muito consistente ao longo dos anos, além de demonstrar pouco prestígio pela competência originária, por dois motivos principais: i) gasta-se muito tempo na instrução probatória das ações originárias enquanto que outros casos já instruídos e de extrema relevância aguardam julgamento; e ii) perde-se em termos de maturidade e reflexão sobre o processo, pois ele não terá uma instância revisora.

Além do mais, o raciocínio judicial dos justices está muito mais acostumado com as expressões argumentativas e especulativas sobre o direito, do que na produção empírica de colheita de fatos e provas, o que envolve realizar interrogatórios, oitivas, perícias, etc.

Por esta razão, a práxis da Corte é a de apontar um Masters para realizar a instrução probatória, ficando ele incumbido das audiências, ouvir as partes, estabelecer os fatos e outros procedimentos que se fizerem necessários, além de escrever um relatório final.

\footnotetext{
${ }^{110}$ PFANDER, James E. op. cit. p 11.
} 
É importante ressaltar que, de maneira geral, a instrução processual, nos EUA, tem um nível de especificidade e detalhamento mais alto do que no Brasil; lá, cada fato e palavra proferida são minuciosamente investigados, com uma exigência de detalhes que geralmente por aqui não é necessária. Isto pode levar a audiências com mais de semanas de duração para a perfeita fixação das condições fáticas sobre as quais haverá o julgamento, outra característica intrínseca do pensamento tópico da common law. Daí a importância do Masters para realizar essa tarefa que tomaria grande parte do tempo já escasso dos justices.

Instruir o processo, portanto, não é algo simples e rápido, em especial, em razão das complexas causas que são postas para julgamento perante a Corte. Um dos casos mais famosos e recentes foi a disputa dos Estados de Nova Iorque e Nova Jersey acerca da ilha de Ellis ${ }^{111}$, local onde está situada a Estátua da Liberdade.

Ocorre que a fronteira entre os Estados americanos geralmente é feita com base no leito dos rios que os dividem, mas, ao longo dos anos, esses leitos se movem, alterando seu curso ou formando novos bancos de terras. Essas novas áreas geralmente são alvo de disputas judiciais, pois não é certo seu legítimo proprietário. Foi exatamente o que aconteceu na ilha de Ellis.

A causa ganhou notoriedade, pois, além de envolver um marco histórico dos EUA (local de desembarque de imigrantes), ainda suscitava a divisão de receitas provenientes do turismo da Estátua da Liberdade, fazendo com que houvesse grande repercussão econômica da decisão. O papel do Masters foi fundamental para avaliar a perícia geológica, os tratados e decisões que se referiam à linha demarcatória e o quanto envolveria de receitas a eventual modificação da fronteira.

Este e outros casos ilustram a complexidade do exercício da competência originária na Suprema Corte que, longe de se esquivar de suas responsabilidades, prefere exercê-las com parcimônia, delegando parte de seu poder a outros órgãos e rejeitando causas que não considera indispensável sua manifestação.

Deste modo, a legislação federal positivada no US Code esposou a construção histórica jurisprudencial da Corte acerca de sua competência originária, fixando-a nos seguintes termos:

\footnotetext{
${ }^{111}$ New Jersey v. New York, 523 U.S. 767.
} 


\section{$\S 1251$. Original jurisdiction}

(a) The Supreme Court shall have original and exclusive jurisdiction of all controversies between two or more States

(b) The Supreme Court shall have original but not exclusive jurisdiction of:

(1) All actions or proceedings to which ambassadors, other public ministers, consuls, or vice consuls of foreign states are parties;

(2) All controversies between the United States and a State;

(3) All actions or proceedings by a State against the citizens of another State or against aliens. ${ }^{112}$

Neste momento, em face do texto normativo e dos precedents analisados, é possível asseverar, sem medo, que há uma abissal diferença entre a competência originária da Suprema Corte e do Supremo Tribunal Federal, o que fatalmente influencia na atuação desses órgãos em sede de jurisdição constitucional.

Se o ativismo é visto como uma imposição ideológica do juiz, que afasta a lei em prol de suas convicções, criando ou modificando políticas públicas, com maior facilidade, isto poderá ser realizado se a Corte tiver uma extensão maior de sua área decisional e instrumentos processuais para tanto.

No caso da Suprema Corte, não nos parece que sua competência originária estimule ou crie um ambiente propício ao ativismo, muito pelo contrário, já que ela tem emprestado interpretação no sentido da diminuição de seu poder nessa seara (autocontenção).

É justamente o contrário do que ocorre com o Supremo Tribunal Federal.

Logo na primeira alínea do inciso primeiro do artigo 102, a Constituição confere o poder de controle de constitucionalidade abstrato das leis, o que certamente coloca em choque o Poder Judiciário e o Legislativo, na medida em que aquele pode anular ou modificar as decisões deste último.

\footnotetext{
112 “\$ 1251 - Jurisdição originária (a) A Suprema Corte terá jurisdição original e exclusiva sobre todos os litígios envolvendo dois ou mais Estados; (b) A Suprema Corte terá jurisdição original mas não exclusiva sobre: (1) Todas as ações e procedimentos em que embaixadores, outros diplomatas, cônsules ou vice cônsules de estados estrangeiro são partes; (2) Todos os litígios envolvendo os Estados Unidos (União) e um Estado; (3) Todas as ações e procedimentos de um Estado contra os cidadãos de outro Estado ou contra estrangeiros." (tradução nossa). É preciso esclarecer que os termos "cases" e "controversies" são utilizados de forma específica na lei estadunidense, embora não gozem de consenso na comunidade jurídica. De acordo com Pfander, trata-se de uma distinção iniciada no caso Cohens v. Virginia (1821) em que o termo "case" está ligado à questão jurídica, enquanto que "controversies" está ligado à parte processual, ou seja, as duas se referem a litígios, mas um tem o foco na matéria e a outra no pólo ativo ou passivo da demanda. PFANDER, James E. op. cit. p. 64-65.
} 
Não se mostra viável qualquer forma de controle normativo abstrato na Suprema Corte em face da prohibition of advisory opinions, que certamente fulminaria qualquer pretensão de análise de constitucionalidade nestes moldes.

Com maior razão, seria esdrúxulo um controle de constitucionalidade por omissão, que além de se referir a um modelo especulativo de pensar, ainda se refere a algo que não existe, uma vez que seu objeto é uma norma que deveria ser editada mas não foi.

Um instituto recursal que alarga demasiadamente a jurisdição do STF e que provavelmente não teria respaldo no direito estadunidense é a reclamação, pois ela não se coaduna com a ripeness, na medida em que deve haver um amadurecimento do processo no seio do Judiciário, sendo prematura a reversão de uma decisão judicial que ainda não passou por todos os estágios recursais.

Outro tipo de competência que certamente coloca o Supremo Tribunal Federal em choque com os poderes políticos é a prerrogativa de foro conferida às autoridades públicas do alto escalão nacional, como o Presidente, Vice-Presidente, Deputados Federais, Senadores, Ministros de Estados e outros.

Muito embora tal prerrogativa seja justificada pelo argumento de que tais personalidades devem ser julgadas por juízes experientes, de notório conhecimento e que não sucumbem às paixões de um processo dessa magnitude, também é certo que coloca a STF, mais uma vez, nos holofotes nacionais sobre temas sensíveis.

Não há dúvidas de que haverá uma pressão maciça advinda de inúmeros setores da sociedade e do próprio corpo político, como demonstrou, entre outros, o caso do "Mensalão".

Apesar de não se questionar a integridade e competência dos Ministros em promover um julgamento imparcial e justo, o fato é que a Corte estará mais à evidência do que de costume, já que não são poucas as prerrogativas, nem poucos os escândalos de corrupção nacionais. Nesse clima de clamor social, o STF certamente fica mais exposto e sujeito às críticas que, fundadas ou não, corroem sua idoneidade e imparcialidade.

Além do mais, a instrução probatória criminal é das mais trabalhosas, aumentando o já saturado labor da Corte. No caso do "Mensalão", por exemplo, dezenas de políticos estão sendo julgados e todo o processo está a cargo de apenas 1 (um) Ministro do Supremo Tribunal Federal. O resultado, após anos de litígio, é que a sociedade continua sem resposta para um dos crimes mais graves já cometidos contra o Estado Democrático de Direito pós-88, e alguns dos delitos já prescreveram. 
Não é por outra razão que a Suprema Corte evita sua competência originária em que necessita realizar instrução processual, além de nomear um Master quando decide admitir a lide.

Além do art. 102 transcrito, há outras competências previstas esparsamente na Constituição que certamente colocam o Supremo Tribunal Federal em situação delicada perante os poderes, como é caso da decretação de intervenção estadual decorrente da violação de princípios constitucionais sensíveis previstos nos artigos 34, VI e 36, III, da Carta Magna. ${ }^{113}$

Trata-se de um tema de nítida natureza política acerca do pacto federativo, que exige uma especial ponderação acerca da desestabilização que a eventual transgressão do Estado-membro provocou na ordem interna, não podendo ser tomado como uma simples violação do Estado-membro a uma regra jurídica formal.

A fluidez dos princípios sensíveis advoga em favor da ausência de parâmetros claros da decretação da intervenção, o que certamente aumenta as especulações acerca de um papel político do STF. É o que pôde ser visto, por exemplo, no pedido de intervenção federal no Estado de São Paulo pelo não pagamento de precatórios, assim como o pedido contra o Distrito Federal em virtude das graves denúncias de corrupção que envolviam seu Governador e parte do Legislativo.

Outras competências, como a edição de súmula vinculante e a arguição de descumprimento de preceito fundamental (ADPF), serão vistas no subcapítulo concernente ao controle de constitucionalidade.

Sendo assim, concluímos pela exponencial diferença entre a competência originária das duas Cortes, sendo certo que a matéria justiciável perante o Supremo Tribunal Federal estimula o surgimento das questões ativistas.

\footnotetext{
${ }^{113}$ Art. 34. A União não intervirá nos Estados nem no Distrito Federal, exceto para:

(...)

VII - assegurar a observância dos seguintes princípios constitucionais:

a) forma republicana, sistema representativo e regime democrático;

b) direitos da pessoa humana;

c) autonomia municipal;

d) prestação de contas da administração pública, direta e indireta.

Art. 36. A decretação da intervenção dependerá:

(...)

II - no caso de desobediência a ordem ou decisão judiciária, de requisição do Supremo Tribunal Federal, do Superior Tribunal de Justiça ou do Tribunal Superior Eleitoral;

III de provimento, pelo Supremo Tribunal Federal, de representação do Procurador-Geral da República, na hipótese do art. 34, VII, e no caso de recusa à execução de lei federal
} 


\subsubsection{Competência recursal}

No que tange à competência recursal do STF e da Suprema Corte, as diferenças não são tão díspares quanto no caso da originária. No Brasil, há duas espécies de recursos principais, o ordinário e o extraordinário, conforme reza o art. 102, incisos II e III:

Art. 102. Compete ao Supremo Tribunal Federal, precipuamente, a guarda da Constituição, cabendo-lhe:

(...)

II - julgar, em recurso ordinário:

a) o "habeas-corpus", o mandado de segurança, o "habeas-data" e o mandado de injunção decididos em única instância pelos Tribunais Superiores, se denegatória a decisão;

b) o crime político;

III - julgar, mediante recurso extraordinário, as causas decididas em única ou última instância, quando a decisão recorrida:

a) contrariar dispositivo desta Constituição;

b) declarar a inconstitucionalidade de tratado ou lei federal;

c) julgar válida lei ou ato de governo local contestado em face desta Constituição.

d) julgar válida lei local contestada em face de lei federal

Embora o rol de hipóteses recursais seja menor do que o da competência originária, em termos substantivos, a extensão da jurisdição da Corte em ambos também é ampla. No caso do recurso extraordinário, em especial, o STF detém legitimidade para conhecer de qualquer causa que contrarie dispositivos constitucionais, o que é extremamente significativo em um modelo analítico e principiológico adotado pelo Constituinte de 88 .

O excessivo uso de termos imprecisos, aliado à ausência de um tratamento técnico mais rigoroso e sistemático da Carta, tem gerado uma infinitude de dúvidas acerca do conteúdo normativo de inúmeras cláusulas, cuja palavra final recairá sobre o STF.

Tomemos, por exemplo, o art. 37, caput, CF onde são estabelecidos os princípios gerais que norteiam a administração pública em linguagem solta e altamente manipulável. ${ }^{114}$ Posteriormente, ao invés de seguir uma lógica de densificação e delimitação dos princípios anteriormente narrados, o legislador trata de matérias esparsas e

114 Art. 37. A administração pública direta e indireta de qualquer dos Poderes da União, dos Estados, do Distrito Federal e dos Municípios obedecerá aos princípios de legalidade, impessoalidade, moralidade, publicidade e eficiência e, também, ao seguinte: (...). 
não necessariamente conexas entre si, cuja inserção no corpo constitucional é duvidosa, já que poderiam ser melhor tratadas em leis infraconstitucionais.

Para completar, os enunciados são constantemente alterados, como é o caso do inciso XI, que trata do teto remuneratório do servidor público e que já sofreu duas modificações por conta da EC 19/98 e EC 41/03 ${ }^{115}$. A mudança legislativa, obviamente, exigirá uma reinterpretação constitucional do STF sobre cada uma dos textos, que, no mínimo, precisará se manifestar sobre os efeitos temporais de cada um dos dispositivos revogados ou recém positivados.

No atual modelo jurisdicional, teríamos as seguintes hipóteses de litígio: em primeiro lugar, caberá arguição sobre a constitucionalidade da própria emenda que alterou o inciso em controle abstrato. Assentada sua adequação ao Texto Magno, em segundo lugar, será cabível recurso extraordinário sobre toda e qualquer decisão de todo e qualquer tribunal do país que "contrariar" o dispositivo em tela, o que na prática, quer dizer que o STF terá que delimitar o sentido do enunciado normativo para que seja possível aferir o que está de acordo ou contra ele. Isto nem sempre é resultado do julgamento de apenas um processo, uma vez que o mesmo dispositivo pode ter diversos efeitos que nem sempre podem ser conhecidos na mesma ação.

Em um terceiro momento, caberá Recurso Extraordinário sobre atos ou leis dos governos locais que contrariarem a norma constitucional, o que faltamente ocorrerá pois

\footnotetext{
${ }^{115}$ Texto original da Constituição de 1988: XI - a lei fixará o limite máximo e a relação de valores entre a maior e a menor remuneração dos servidores públicos, observados, como limites máximos e no âmbito dos respectivos poderes, os valores percebidos como remuneração, em espécie, a qualquer título, por membros do Congresso Nacional, Ministros de Estado e Ministros do Supremo Tribunal Federal e seus correspondentes nos Estados, no Distrito Federal e nos Territórios, e, nos Municípios, os valores percebidos como remuneração, em espécie, pelo Prefeito;

Texto com a redação da EC 19/08: XI - a remuneração e o subsídio dos ocupantes de cargos, funções e empregos públicos da administração direta, autárquica e fundacional, dos membros de qualquer dos Poderes da União, dos Estados, do Distrito Federal e dos Municípios, dos detentores de mandato eletivo e dos demais agentes políticos e os proventos, pensões ou outra espécie remuneratória, percebidos cumulativamente ou não, incluídas as vantagens pessoais ou de qualquer outra natureza, não poderão exceder o subsídio mensal, em espécie, dos Ministros do Supremo Tribunal Federal;

Texto atual com a redação da EC 41/03: XI - a remuneração e o subsídio dos ocupantes de cargos, funções e empregos públicos da administração direta, autárquica e fundacional, dos membros de qualquer dos Poderes da União, dos Estados, do Distrito Federal e dos Municípios, dos detentores de mandato eletivo e dos demais agentes políticos e os proventos, pensões ou outra espécie remuneratória, percebidos cumulativamente ou não, incluídas as vantagens pessoais ou de qualquer outra natureza, não poderão exceder o subsídio mensal, em espécie, dos Ministros do Supremo Tribunal Federal, aplicando-se como limite, nos Municípios, o subsídio do Prefeito, e nos Estados e no Distrito Federal, o subsídio mensal do Governador no âmbito do Poder Executivo, o subsídio dos Deputados Estaduais e Distritais no âmbito do Poder Legislativo e o subsídio dos Desembargadores do Tribunal de Justiça, limitado a noventa inteiros e vinte e cinco centésimos por cento do subsídio mensal, em espécie, dos Ministros do Supremo Tribunal Federal, no âmbito do Poder Judiciário, aplicável este limite aos membros do Ministério Público, aos Procuradores e aos Defensores Públicos;
} 
inúmeras leis locais estão vinculadas ao texto constitucional, como deve ser. A alteração da Carta Magna exigirá uma readaptação dessas leis, o que não ocorre de forma automática e nem sempre é feito, gerando mais uma avalanche de processos por todo o país.

Por fim, a modificação da Constituição provavelmente exigirá a alteração da lei federal que trata sobre o tema, o que poderá também ser questionado em face da lei local, nos termos da alínea "d".

Todas essas hipóteses de exercício de jurisdição constitucional descrevem, com certeza, situações polêmicas e de grande impacto na vida política, econômica e social do país, já que terão reflexos de milhões ou bilhões de reais nos cofres públicos e alterarão os vencimentos de milhares ou milhões de servidores.

Mais uma vez, o ativismo judiciário encontrará um terreno fértil para se manifestar.

Portanto, uma simples alteração em um inciso constitucional como o teto do funcionalismo público, possui um efeito devastador sobre a jurisdição do Supremo Tribunal Federal, gerando um quadro caótico de litigiosidade e cuja natureza da demanda será de forte apelo ativista.

Isto seria menos desolador se não correspondesse, efetivamente, à presente realidade que aflige o Poder Judiciário no tema do teto do funcionalismo público nacional.

O exemplo exposto parece ser suficiente para demonstrar a amplitude da competência recursal do Supremo Tribunal Federal ainda que seu rol seja diminuto, e de como o ativismo pode se manifestar nela de acordo com o modelo constitucional adotado pelo próprio legislador e suas alterações feitas ao longo dos anos.

Nos Estados Unidos, a competência recursal da Suprema Corte também é ampla e conta com um elemento de distinção fundamental em relação à brasileira: sua fixação por lei ordinária do Congresso.

A Constituição estadunidense apenas estabelece as matérias justiciáveis, ou seja, tudo aquilo que o Poder Judiciário pode conhecer e decidir sobre. Em espécie, prevê apenas a competência originária da Suprema Corte, deixando para a lei federal toda sua competência recursal e a organização da justiça federal e estadual.

Este é o teor do artigo $3^{\circ}$, segunda seção: 
SECTION 2. 1 The judicial Power shall extend to all Cases, in Law and Equity $^{116}$, arising under this Constitution, the Laws of the United States, and Treaties made, or which shall be made, under their Authority;- to all Cases affecting Ambassadors, other public Ministers and Consuls;to all Cases of admiralty and maritime Jurisdiction;- - to Controversies to which the United States will be a party; - to Controversies between two or more States;-between a State and Citizens of another State;between Citizens of different States,-between Citizens of the same State claiming Lands under Grants of different States, and between a State, or the Citizens thereof, and foreign States, Citizens or Subjects. ${ }^{117}$

2 In all Cases affecting Ambassadors, other public Ministers and Consuls, and those in which a State shall be Party, the supreme Court shall have original Jurisdiction. In all the other Cases before mentioned, the supreme Court shall have appellate Jurisdiction, both as to Law and Fact, with such Exceptions, and under such Regulations as the Congress shall make. ${ }^{118}$

A atual competência recursal da Suprema Corte está positivada no US Code, que apresenta distintas hipóteses de recorribilidade em razão da jurisdição em que tramita o processo. Faremos menção apenas à jurisdição federal e estadual, não tratando dos casos de possibilidade recursal das decisões da Suprema Corte de Porto Rico, nem da Corte de Apelação das Forças Armadas, por apresentarem traços específicos da organização judiciária estadunidense e representarem um número baixíssimo de casos julgados na Suprema Corte.

No caso da jurisdição federal, o texto está assim redigido:

$\S 1254$. Courts of appeals; certiorari; certified questions

Cases in the courts of appeals may be reviewed by the Supreme Court by the following methods:

(1) By writ of certiorari granted upon the petition of any party to any civil or criminal case, before or after rendition of judgment or decree;

(2) By certification at any time by a court of appeals of any question of law in any civil or criminal case as to which instructions are desired, and upon such certification the Supreme Court may give binding

\footnotetext{
${ }^{116}$ Para uma visualização histórica sobre as jurisdições da law e da equity, ver SOARES, Guido Fernando Silva. Common Law: introdução ao direito dos EUA. 2a ed. São Paulo: Editora Revista dos Tribunais, 2000. p. 32-37.

117 “O Poder Judicial compreenderá todos os litígios em Law e Equity, originados sob esta Constituição, as leis dos Estados Unidos e os Tratados realizados, ou que serão realizados, sob sua autoridade; a todos os litígios que afetem embaixadores, diplomatas e cônsules; a todos os litígios da jurisdição do almirantado e marítima; aos litígios em que os Estados Unidos [União] seja parte; aos litígios entre dois ou mais Estados; entre um Estado e o cidadão de outro Estado; entre cidadãos de Estados diferentes; entre cidadãos do mesmo Estado reivindicada a propriedade de concessões feitas por Estados diferentes, e entre um Estado, ou os cidadãos do mesmo, e Estados, cidadãos ou questões internacionais. (tradução nossa)

118 "Em todos os litígios envolvendo Embaixadores, diplomatas e cônsules e naqueles em que um Estado será parte, a Suprema Corte terá jurisdição originária. Nos outros litígios antes mencionados, a Suprema Corte terá jurisdição recursal, tanto quanto ao direito e aos fatos, respeitadas as exceções, e de acordo com as regulamentações que o Congresso editará." (tradução nossa)
} 
instructions or require the entire record to be sent up for decision of the entire matter in controversy. ${ }^{119}$

Quanto à primeira hipótese, não há requisito específico para a Suprema Corte conhecer de qualquer causa julgada pelas Cortes de Apelação da jurisdição federal, bastando a interposição do writ of certiorari para requerer a revisão do julgamento.

Importa salientar, contudo, que tal writ é de conhecimento discricionário da Corte, ou seja, ela pode admiti-lo ou não a seu bel prazer, não necessitando sequer fundamentar a eventual recusa.

O writ of certiorari não tem similar no direito brasileiro e pode até parecer um instrumento arbitrário à primeira vista. O fato é que a Suprema Corte é ciente da quantidade de litígios que existem no país e que todos eles, de forma direta ou indireta, lidam com temas constitucionais, bastando um advogado habilidoso para demonstrar a existência de uma questão constitucional na causa e a necessidade de manifestação da Corte.

Desse modo, a maneira encontrada pela Suprema Corte para restringir seu volume de trabalho e não acabar julgando todos os processos existentes no país foi por meio de um writ declaradamente discricionário, que sequer tem sua admissibilidade ou recusa fundamentada para não formar jurisprudência que vincule a Corte em casos posteriores.

A Suprema Corte é consciente da influência política que exerce nos EUA, portanto não quer se sentir obrigada a conhecer uma causa polêmica se não considerar que há um ambiente propício para sua manifestação.

Temas como o aborto, a eutanásia, a pena de morte e o casamento homossexual, dialogam com o Texto Constitucional, notadamente com as cláusulas abertas principiológicas. Poderia a Corte exercer jurisdição sobre eles, mas nem por isso o faz, preferindo muitas vezes deixar a questão para a sociedade e os poderes políticos decidirem, em claro exercício de autocontenção (selfrestraint).

Outras vezes, a Corte pode considerar que não possui força suficiente para concretizar a sua decisão, tema que será debatido mais detalhadamente em subcapítulo à parte (implementation process). Uma questão interessante que nunca foi admitida pela

\footnotetext{
${ }^{119}$ Litígios das Cortes de Apelação podem ser revistos pela Suprema Corte por meio dos seguintes métodos: 1 pelo writ of certiorary concedido por meio de petição de qualquer parte de qualquer litígio civil ou criminal antes ou depois de proferida a decisão. 2 por certification, em qualquer tempo, de uma Corte de Apelação sobre qualquer questão legal em qualquer ação civil ou criminal em que instruções são desejáveis, e em função desta certification a Suprema Corte fornecerá instruções vinculantes ou requererá o envio integral dos autos para a decisão de toda a matéria controvertida. (tradução nossa)
} 
Corte foi a da Guerra do Vietnã, em que o Poder Executivo determinou a invasão do país sem autorização do Congresso, violando disposição legal expressa. Apesar de ser uma questão juridicamente simples, a Suprema Corte sabia que seu eventual julgamento de inconstitucionalidade poderia ser facilmente desprezado pelo Executivo, que provavelmente manteria a guerra e desprestigiaria a decisão judicial.

O writ of certiorari, portanto, apesar de sua natureza discricionária, é, sem dúvida nenhuma, um importante instrumento de autocontenção da Suprema Corte, além de garantir que os processos serão bem julgados com presteza, não afogando-se em milhares de recursos.

Outro aspecto importante é que a negativa de admissibilidade das ações aumenta a responsabilidade e credibilidade dos Tribunais Recursais de segunda instância, já que sua decisão será definitiva. Isso faz com que os litigantes atuem com maior intensidade e a própria sociedade exija boa qualidade das decisões destes Tribunais, já que eles não são mais uma simples instância de passagem e sua decisão tem grandes chances de ser a palavra final do Judiciário.

No Brasil, tentativa similar de restrição de conhecimento de processos foi introduzida pela Emenda Constitucional n. 45, que criou o requisito da Repercussão Geral no Recurso Extraordinário.

Ao contrário do writ of certiorari, que não tem qualquer parâmetro traçado em lei ${ }^{120}$, a repercussão geral tem como requisito a existência de "questões relevantes do ponto de vista econômico, político, social ou jurídico, que ultrapassem os interesses subjetivos da causa” (art. 543-A, §1, CPC). A linguagem excessivamente fluida do texto normativo, ao fim e ao cabo, não confere muita segurança e delimitação quanto às hipóteses de reconhecimento da repercussão geral, sendo questionável se não há uma efetiva discricionariedade velada.

Apesar da similaridade da grande liberdade de manejo do writ of certiorari e da repercussão geral, sua utilização é diametralmente oposta nos dois países. Enquanto, nos EUA, a Suprema Corte apenas admite aproximadamente 1 a $2 \%$ das petições a ela dirigidas (média dos últimos anos), no Brasil, o índice de reconhecimento de repercussão geral está em quase $70 \%{ }^{121}$

\footnotetext{
${ }^{120}$ A Rule 10 da Suprema Corte estabelece alguns critérios de conflitos de interpretação da lei para conhecimento do writ, mas ela mesma não os segue à risca.

${ }^{121}$ Sobre os Estados Unidos, ver BAUM, Lawrence, op. cit. p. 85 e no Brasil ver o site do Supremo Tribunal Federal 
Ao lado do writ of certiorari, a segunda hipótese de competência recursal da Suprema Corte é a certification, espécie de consulta à Corte sobre a correta interpretação da lei em um determinado caso concreto. Seguindo a linha de raciocínio desenvolvida na prohibition against advisory opinion, a Corte tem sido totalmente refratária a esse instituto, e os próprios Tribunais não gostam de utilizá-lo, pois pode ser interpretado como a ausência de conhecimento suficiente sobre a lei.

No que tange a competência recursal na jurisdição estadual, o US Code reza que:

\section{State courts; certiorari}

(a) Final judgments or decrees rendered by the highest court of a State in which a decision could be had, may be reviewed by the Supreme Court by writ of certiorari where the validity of a treaty or statute of the United States is drawn in question or where the validity of a statute of any State is drawn in question on the ground of its being repugnant to the Constitution, treaties, or laws of the United States, or where any title, right, privilege, or immunity is specially set up or claimed under the Constitution or the treaties or statutes of, or any commission held or authority exercised under, the United States;

(b) For the purposes of this section, the term "highest court of a State" includes the District of Columbia Court of Appeals. ${ }^{122}$

A tradução literal do dispositivo encontra alguns óbices, dada a inexistência de alguns institutos similares no direito brasileiro, como a doutrina dos titles, rights, privileges e immunities. Desse modo, elencamos abaixo as hipóteses recursais mais importantes e que podem ser comparadas diretamente com o sistema brasileiro:

a) decisão final da Suprema Corte do Estado que envolva a validade de um tratado ou lei federal;

b) decisão final da Suprema Corte do Estado que envolva a constitucionalidade de uma lei estadual;

\footnotetext{
$<$ http://www.stf.jus.br/portal/cms/verTexto.asp?servico=jurisprudenciaRepercussaoGeral\&pagina=numeroR epercussao $>$. Acesso em 30.11.2011

${ }^{122}$ A tradução literal do dispositivo não reflete com precisão a competência da Corte comparada aos institutos jurídicos brasileiros. Todavia, apenas para uma compreensão preliminar do texto, apresentamos a seguinte tradução: “a ) Decisões finais proferidas pela Corte Suprema de um Estado, podem ser revistas pela Suprema Corte por writ of certiorari onde a validade de um tratado ou de uma lei dos Estados Unidos é questionada ou onde a validade de uma lei de qualquer Estado é questionada sob o fundamento de sua contrariedade a Constituição, tratados ou leis dos Estados Unidos, ou onde qualquer título, direito, privilégio ou imunidade é estabelecida ou reclamada com base na Constituição ou tratados e leis, ou qualquer comissão recebida ou autoridade exercida nos Estados Unidos [União]. b) para os fins desta Seção, o termo 'Suprema Corte de um Estado', inclui a Corte de Apelação do Distrito de Columbia". (tradução nossa)
} 
c) decisão final da Suprema Corte do Estado que envolva a legalidade de uma lei estadual face a lei federal ou tratado.

O que se nota é que a Suprema Corte exerce o controle de legalidade e constitucionalidade das leis em sede de jurisdição estadual, tanto em relação às leis federais quanto estaduais, o que o Supremo Tribunal Federal também realiza em grande medida. Apesar disso, a Suprema Corte tem preferido manter a autonomia das Cortes estaduais e focar sua atuação na jurisdição federal, de onde provém a maioria dos casos admitidos pelo writ of certiorari ${ }^{123}$.

A autocontenção da Corte na jurisdição estadual tem um dos seus fundamentos nos históricos embates entre a autonomia dos Estados e o poder unificador da União, o que se refletiu nos precedents. No caso Martin v. Hunter's Lesse de 1816, questionava-se a legalidade da lei do Estado de Virgínia que previa o confisco de bens daqueles que eram fiéis à Coroa Britânica, em conflito com o Tratado de Paz de 1783 entre EUA e Inglaterra. Apesar do julgamento de inconstitucionalidade pela Suprema Corte, o Estado de Virgínia recusava-se a segui-lo, negando jurisdição da Corte sobre decisões do órgão judiciário estadual.

Em sentido contrário, a Suprema Corte posteriormente limitou a sua atuação recursal sobre a jurisdição estadual no caso Murdock v. Memphis de 1875, ocasião em que se firmou a adequate and independent state grounds doctrine, consubstanciada na negativa de jurisdição da Suprema Corte quando o caso versado foi decidido, fundamentalmente, sob questão estadual, ainda que haja alguns reflexos sobre leis federais. ${ }^{124}$

Sendo assim, podemos asseverar, de imediato, que a Suprema Corte tem ampla competência sobre a jurisdição estadual, mas prefere atuar com maior afinco sobre as leis federais. Isto não quer dizer que o ativismo ocorra com maior frequência nesta última, mesmo porque, as acusações de julgamentos ideológicos dos justices são feitos com grande vigor pelos Estados-membros, que veem sua autonomia reduzida a partir do papel unificador da Suprema Corte.

No próximo subcapítulo veremos como é exercido especificamente o controle de constitucionalidade das leis no STF e na Suprema Corte, uma vez que, sem sombras de dúvidas, é essa competência que suscita mais questionamentos sobre uma eventual postura ativista das Cortes.

\footnotetext{
${ }^{123}$ PFANDER, James E. op. cit. p. 67

${ }^{124}$ PFANDER, James E. op. cit. p. 77-82
} 


\subsubsection{O controle de constitucionalidade vs. a judicial review}

No exame desses dois institutos jurídicos de suma importância para o tema do ativismo judicial, focaremos dois aspectos principais: primeiro, suas concepções históricas e, segundo, a extensão de seu exercício nos atuais contornos constitucionais. Com isso pretendemos verificar como as comunidades jurídica e política enxergam esses institutos desde o seu nascedouro, e se suas expectativas estão de acordo com a atual extensão desses poderes.

Historicamente, o controle de constitucionalidade das leis nas democracias ocidentais está fortemente ligado à decisão Marbury vs. Madison da Suprema Corte estadunidense de 1803. Embora não haja dúvidas de que outros ordenamentos jurídicos e organizações estatais já previssem uma forma de controle de hierarquia de normas ${ }^{125}$, o fato é que esse precedente é referência constante nos estudos do constitucionalismo moderno, em especial, do controle difuso, ao lado do controle abstrato criado mais de um século depois por Kelsen.

O que se nota é que a maioria da doutrina toma Marbury como um reduto de salvaguarda da Constituição e da sociedade contra os abusos do homem no exercício do poder político, fartamente explorados na antropologia pessimista de Locke $^{126}$ e Montesquieu. $^{127}$

Entretanto, isso não condiz com algumas leituras históricas realizadas por renomados juristas estadunidenses, notadamente, Laurence Tribe e Bruce Ackerman.

Para o primeiro, há uma falha lógica na construção conceitual de Marbury, além de motivações políticas e pessoais de Marshall na decisão. Para o segundo, a judicial review é resultado de um grave embate entre federalistas e republicanos que resultou no uso do Poder Judiciário como ator político-partidário nos EUA.

\footnotetext{
${ }^{125}$ RAMOS, Elival da Silva. op. cit. p. 19 e ss.

${ }^{126}$ LOCKE, John. Two treatises of government and a letter concerning toleration. Binghamton: Yale University Press, 2003.

${ }^{127}$ MONSTEQUIEU, Charles-Louis de Secondatt, barão de la Brède e de. op. cit.
} 
Em sua obra American Constitutional Law ${ }^{128}$, Laurence Tribe aduz que o controle de constitucionalidade não é uma decorrência lógica da supremacia da Constituição, como ficou assentado em Marbury. De fato, se uma lei é hierarquicamente superior, então todas as demais devem estar em conformidade com ela, o que não quer dizer que o Poder Judiciário deva ser o responsável por essa análise, uma vez que sua função original - até então exercida antes de 1803 -, era simplesmente interpretar e aplicar a lei, e não anulá-la.

Trata-se, portanto, de uma inferência feita à Constituição que não contemplava expressamente tal prerrogativa ao Judiciário, e que poderia ser muito bem ser exercida por outros Poderes, como o Executivo e o Legislativo, já que o segundo, especificamente, tem o poder de aprovar e revogar as leis, nada obstando que ele observasse os termos constitucionais no momento de elaboração legislativa.

Poder-se-ia argumentar que a ideia de checks and balances advoga pelo controle recíproco dos Poderes, sendo preferível que os atos emanados por um deles sejam controlados por outro. Contudo, essa é uma ideia que deriva da concepção dogmática de separação de poderes atualmente aceita, e não da leitura do texto constitucional estadunidense à época. Se considerarmos Marbury no contexto interpretativo legalista do início do século XIX, ela pode ser considerada como uma decisão ativista, na medida em que os juízes expandiram seus poderes para além do texto constitucional.

Outra primorosa leitura do supracitado precedent pode ser encontrada em The Failure of the Founding Fathers ${ }^{129}$, de Bruce Ackerman. Nessa obra, o autor traz à tona o contexto político das eleições presidenciais estadunidenses de 1800, em que o Partido Federalista, favorável à reeleição de John Adams (sucessor de George Washington), travava vigoroso embate com o recém-criado Partido Republicano, cujo candidato à presidência era Thomas Jefferson (até então vice-presidente ao lado de Adams).

O fato primordial era que os federalistas consideravam o Partido Republicano como uma verdadeira ameaça ao país, uma vez que o último tinha uma ideologia descentralizadora, e, portanto, não via com o mesmo afinco a necessidade de uma União forte. Para os federalistas, a centralização era condição sine qua non para a própria existência dos Estados Unidos que poderia ser devastado por uma guerra a qualquer momento, caso não houvesse um poder militar central robusto, além de ser importante

\footnotetext{
${ }^{128}$ TRIBE, Laurence H. American Constitutional Law. vol. 1. 3.ed. Nova Iorque, Nova Iorque: Foundation Press, 2000.

${ }^{129}$ ACKERMAN, Bruce. op. cit.
} 
estrategicamente para os Estados-membros a existência de um ente unificador em determinadas políticas públicas.

Neste clima de intensa hostilidade política, Thomas Jefferson foi eleito Presidente, após uma tumultuada eleição que teve dezenas de votações até chegar a um veredicto final.

Tendo perdido a presidência e receoso dos enormes riscos que os republicanos pretensamente ofereciam, John Adams, antes de terminar seu mandato, decidiu criar um bunker de salvaguarda dos ideais federalistas, acreditando que deveria refrear de qualquer forma os impulsos do novo Presidente para preservar a Nação. O locus escolhido foi justamente o Poder Judiciário, onde os federalistas poderiam ter o controle da aplicação das leis, e Adams, com base em seus poderes presidenciais, poderia nomear os juízes sem grandes intervenções dos demais Poderes.

No conhecido episódio dos midnight jugdes (juízes da meia-noite), Adams realizou inúmeras nomeações por todo o país, inclusive, retirando políticos influentes no Senado para inseri-los em Cortes de Apelação, assegurando que os federalistas estariam amplamente representados no sistema judiciário como um todo.

Para a presidência da Suprema Corte estava reservado o nome de John Marshall, homem de confiança e que exercia o cargo de Secretário de Estado, responsável, inclusive, pela entrega dos atos de nomeação aos novos juízes. Por um infeliz descuido, antes de deixar seu cargo, Marshall não entregou uma dessas nomeações, precisamente a de William Marbury, sendo que o novo Secretário, James Madison, se recusava a fazê-lo.

É importante ter em mente que, no início do século XIX, a prova de um ato jurídico de nomeação era documental, e não havia qualquer forma de registro público a todos acessível, como o Diário Oficial que existe hodiernamente. Para os juízes provarem que foram nomeados, precisavam ter consigo o documento de nomeação, assinado e com o selo presidencial.

Sendo assim, Marbury optou por ajuizar uma ação perante a Suprema Corte nos termos do Judiciary Act de 1789, que previa a competência originária do órgão para a concessão do writ of mandamus, uma espécie de ordem judicial que obrigaria Madison a efetivar o ato de nomeação.

Rigorosamente falando, Marshall, então chief justice da Suprema Corte, sequer poderia ter julgado o caso, pois era suspeito como parte interessada, uma vez que ele mesmo era o responsável pela nomeação que nunca fora entregue e que agora era pleiteada judicialmente. 
Marbury v. Madison, portanto, gira em torno da nomeação de Marbury a juiz de paz realizada por Marshall e não entregue pelo seu sucessor Madison, sendo que os dois últimos eram de partidos opostos e estavam inseridos em um ambiente político de elevada animosidade.

Embora o Judiciary Act de 1789 claramente previsse a concessão do writ of mandamus pela Suprema Corte, Marshall estava ciente de que se a deferisse, havia grande chance de tal decisão não ser cumprida por Madison, já que estava instruído por Thomas Jefferson a refutar eventual ordem da Corte nesse sentido. Ou seja, a ordem judicial seria deliberadamente desrespeitada e a Corte pouco poderia fazer a respeito.

Além de gerar um desgostoso embate institucional que não favoreceria a nação recém-criada, a concessão do writ of mandamus desprestigiaria a Corte e sua autoridade, diminuindo a influência dos federalistas no seio do Poder Judiciário.

Sendo assim, a opção de Marshall foi a de reconhecer o direito de Madison, mas não conceder o writ, asseverando que a lei que o previa era inconstitucional. Portanto, a Corte afirmou o seu poder de judicial review e julgou nulo o dispositivo do Judiciary Act de 1789 que lhe conferia o poder de emitir o writ of mandamus, aduzindo que o rol constitucional de competências e ações originárias da Suprema Corte era exaustivo.

Apesar dos elogios e aplausos de parte da doutrina quanto ao caráter corajoso e libertário do precedent, alguns estudiosos asseveram que a decisão de Marshall foi um recuo estratégico para o dilema em que ele estava inserido. Ao mesmo tempo em que não se indispôs com o Executivo com a ordem de mandamus, ainda estabeleceu as bases para um novo poder da Corte, ainda mais incisivo e que não constava da Constituição, o judicial review.

Ackerman acata tal pensamento e vai além. Para ele, o judicial review é decorrência de um embate partidário que a Constituição não foi capaz de refrear, pois ela não previu que haveria uma disputa ideológico-partidária pelo poder de tal monta. Aduz o cientista político que as premissas constitucionais eram baseadas na existência de um poder presidencial unificador e erigido consensualmente pelas forças políticas, o que se concretizou inicialmente na figura de George Washignton. Com a sua morte, não havia outra pessoa que o substituísse à altura, o que gerou embates pelo nome do sucessor e a criação de partidos adversários.

Uma vez que a luta partidária pelo poder não encontrava freios e limites constitucionais, o uso do Judiciário como um ator político não foi frontalmente rejeitado desde o início, o que marcou profundamente a história estadunidense. Isto não quer dizer 
que o Judiciário se transformou em uma longa manus dos partidos políticos, mesmo porque, em momentos ulteriores, ele afirmará sua independência com muita propriedade, mas apenas que ele não está alheio ao campo político e que não há a radical separação de poderes dogmaticamente pensada.

Pelas leituras de Tribe e Ackerman, percebe-se que está arraigado na cultura estadunidense o uso político do Poder Judiciário e da judicial review, não podendo a última ser considerada unicamente como um artifício corajosamente criado por um homem (Marshall), em prol da salvaguarda da Constituição - o que geralmente é feito no Brasil.

Nossa história constitucional é significativamente diversa da estadunidense, sendo que o controle de constitucionalidade, dentre nós, foi defendido originalmente por Ruy Barbosa em seu célebre escrito Atos Inconstitucionais ${ }^{130}$, em que ele teria importado o modelo da judicial review criado em Marbury e advogado pela sua adoção na Constituição de 1891, o que acabou sendo efetivado.

O controle de constitucionalidade difuso no Brasil, portanto, não foi uma criação jurisprudencial de poucos juízes, mas uma adoção da comunidade política republicana, o que lhe conferiu maior credibilidade e legitimidade. Dissertando acerca da distinção entre a origem do controle de constitucionalidade no Brasil e a judicial review nos Estados Unidos, citamos o exemplar exame histórico do ilustre professor Elival da Silva Ramos:

Se nos Estados Unidos a competência do Poder Judiciário para efetuar o controle de constitucionalidade dos atos legislativos exigiu elaborada construção jurisprudencial, combinando o princípio da supremacia da Constituição com uma compreensão precisa dos limites e possibilidades função jurisprudencial, no Brasil tal fiscalização não admitia, em princípio, dúvida alguma, pois embora a nossa primeira Constituição republicana não consagrasse, de modo direto, a possibilidade de a magistratura nacional recusar a aplicação de leis inconstitucionais, indiretamente o fazia, nos termos de seu art. $59, \S 1^{\circ}$, alíneas $a$ e $b^{131}$

Mais adiante, prossegue a análise e aduz que:

Em 20 de novembro do ano seguinte aos Atos inconstitucionais (1894), foi editada a Lei Federal n. 221, que completou a organização da Justiça Federal, trazendo a lume disposição normativa, rara em sistemas de controle de inconstitucionalidade legislativa, no sentido de atribuir

\footnotetext{
${ }^{130}$ BARBOSA, Rui. Atos inconstitucionais. 1. ed. Campinas: Russel, 2003.

${ }^{131}$ RAMOS, Elival da Silva. op. cit. p. 185.
} 
expressamente aos juízes e tribunais o dever (poder) de recusar a aplicação de leis e regulamentos contrários à Constituição. Estava, portanto, definitivamente incorporado ao direito pátrio um sistema de controle de constitucionalidade das leis de natureza jurisdicional e repressiva, calcado inteiramente no sistema-padrão estadunidense, com o qual compartilhava as características determinantes. ${ }^{132}$

Esse sistema difuso de controle de constitucionalidade desde então esteve presente no ordenamento jurídico nacional, e enraizou-se de tal maneira que sequer está positivado no Texto Magno de 1988, já que há um consenso sobre sua decorrência implícita.

Por sua vez, no que tange ao controle abstrato de constitucionalidade, podemos asseverar desde logo que ele não existe nos Estados Unidos, enquanto que, no Brasil, teve um peculiar e sólido desenvolvimento histórico.

Desde a Constituição de 1934, diversos debates foram travados a fim de se adotar no Judiciário brasileiro um modelo de controle abstrato e concentrado de constitucionalidade de inspiração kelseniana, cuja doutrina já repercutia entre nós e se fazia presente em algumas Constituições européias. Tal aspiração tomou corpo em alguns projetos apresentados à Constituinte em que se sustentava a necessidade de tal controle face o esgotamento do padrão estadunidense, em que não há a possibilidade de se intervir abstratamente no ordenamento jurídico e não se produz imediatos efeitos erga omnes ${ }^{133}$.

Inobstante a rejeição de tais propostas, o fato é que a Constituição de 1934 positivou a chamada ação de representação interventiva de inconstitucionalidade por violação aos princípios sensíveis, em que o Judiciário podia analisar a constitucionalidade da lei federal que determinava a intervenção em determinado Estado-membro, com base na incompatibilidade de alguma de suas normas ou condutas face a Constituição. Na Constituição de 1946, esse instituto foi aprimorado de modo que o Supremo Tribunal Federal deveria, previamente à decretação de intervenção por lei federal, julgar a inconstitucionalidade do ato normativo estadual que era reputado contrário aos princípios sensíveis, funcionando como uma autorização para os órgãos federais emitiram a intervenção.

Nessa representação interventiva, o julgamento da lei ou ato estadual reputado inconstitucional era realizado concentradamente no Supremo Tribunal Federal e de forma

\footnotetext{
${ }^{132}$ RAMOS, Elival da Silva. op. cit. p. 187.

${ }^{133}$ RAMOS, Elival da Silva. ib.. p. 189-193.
} 
abstrata, isto é, alheio a qualquer litígio subjetivo, condição sine qua non do modelo de controle de matiz estadunidense. Aduz o mestre Elival da Silva Ramos que:

Ansiavam os operadores do direito pátrio por um instrumento com a dimensão da ação direta genérica declaratória de inconstitucionalidade, a tal ponto que, ao delinear as características da representação interventiva, chegou o Supremo Tribunal Federal a antecipar o desenho de um modelo de controle de constitucionalidade em via principal, com feições abstratas, que rigorosamente ainda não havia. ${ }^{134}$

Desse modo, o Supremo Tribunal Federal passou a julgar abstratamente a constitucionalidade de determinados atos normativos com efeitos erga omnes, abrindo brecha para o controle de constitucionalidade de matiz kelseniana que foi positivado posteriormente pela Emenda Constitucional n. 16 de 1965 . $^{135}$

Hodiernamente, a Constituição de 1988 consagra expressamente o controle abstrato de constitucionalidade das leis por meio de inúmeros instrumentos processuais (ADI, ADC, etc.), enquanto que o controle difuso é considerado como um poder constitucional implícito que compete a todo e qualquer juiz exercer.

A história do controle de constitucionalidade no Brasil, a princípio, não parece mostrar que houve uma vinculação de seu uso para fins partidários, embora nossa pesquisa tenha sido restrita. Esta assertiva, entretanto, deve excepcionar os períodos em que o Judiciário como um todo foi chamado a atuar junto ao Executivo, especialmente durante a ditadura getulista e o regime militar.

De qualquer maneira, o fato é que a doutrina brasileira pós-88 costuma tratar o controle de constitucionalidade como um instrumento de garantia da supremacia da Constituição e da separação dos poderes, em um claro viés idealista de fiscalização puramente jurídica e técnica feita por um Judiciário neutro e independente. Essa concepção é diversa da doutrina estadunidense de judicial review, que frequentemente insere a Suprema Corte nas questões de políticas públicas e não considera haver uma separação rigorosa entre os critérios jurídicos e políticos de controle, principalmente após o fracasso da political question doctrine.

Desse modo, concluímos que, em uma abordagem histórica, a judicial review e o controle de constitucionalidade, embora concebidos como um instrumento de garantia de supremacia da Constituição, têm ambientes de formação distintos no Brasil e nos Estados

\footnotetext{
${ }^{134}$ RAMOS, op. cit. p. 208.

${ }^{135}$ RAMOS, ib. p. 203-223.
} 
Unidos, na medida em que a primeira esteve precocemente inserida nas disputas partidárias, e o segundo, notadamente no período pós-88, esteve mais vinculado a uma visão idealista de fiscalização das leis por critérios unicamente jurídicos, realizada por um órgão neutro e independente.

O segundo ponto que consideramos de fundamental importância é a extensão do poder de controle de constitucionalidade, isto é, sobre quais espécies de atos normativos ele pode incidir, tanto no Brasil quanto nos Estados Unidos.

No Brasil, sob a égide da Constituição de 1988, o controle abstrato realizado via Ação Direta de Inconstitucionalidade (ADI) pode recair sobre "lei ou ato normativo federal ou estadual", nos temos do art. 102, I, “a”, CF. Essa expressão tem tido interpretação amplíssima de acordo com a doutrina e jurisprudência nacional, ${ }^{136}$ o que quer dizer que toda forma de ato normativo pode ser fiscalizada, por exemplo: leis ordinárias, leis complementares, medidas provisórias, lei constitucional estadual, resoluções, decretos, portarias, etc. ${ }^{137}$

No caso das leis e atos normativos municipais, eles não podem ter sua constitucionalidade questionada na forma concentrada no STF via ADI, apenas pelo controle difuso que, diga-se de passagem, também pode ser utilizado para arguir a inconstitucionalidade das leis e atos normativos federais e estaduais.

Disto se extrai que todo e qualquer ato normativo na esfera federal, estadual ou municipal pode sofrer controle judicial de constitucionalidade, sendo que alguns possuem mais de um mecanismo processual para tanto.

Uma espécie normativa que deve ser analisada em particular é a Emenda Constitucional, haja vista que ela é dotada de elevada carga de legitimidade democrática e representa as opções políticas fundamentais do Estado, além de revogar, modificar ou acrescentar dispositivos ao próprio parâmetro originário de controle, a Constituição.

Nessa seara, o Supremo Tribunal Federal tem adotado a teoria clássica do Poder Constituinte Originário e Derivado para assentar que o segundo é limitado e não pode

\footnotetext{
${ }^{136}$ MORAES, Alexandre de. op. cit. p. 733-734.

${ }^{137}$ No caso de normas infralegais, como os decretos e portarias, não é claro se eles devem sofrer controle de legalidade em face da lei que os originou, ou se devem ser fiscalizados diretamente em face da Constituição. O problema que se põe é que, se o decreto é inconstitucional, provavelmente a lei também o será, exceto se o decreto extrapolou os limites dos parâmetros legais, caso em que poderia sofrer duplo controle face a lei e a Constituição. O problema é agravado no caso dos decretos autônomos, cuja legitimidade é questionada por alguns doutrinadores, pois eles não derivam da lei, mas da própria fonte constitucional. A tendência no STF é de se admitir o controle direto de inconstitucionalidade sobre qualquer ato normativo, seja primário ou secundário.
} 
contrair o que foi estipulado pelo primeiro, cabendo à Corte julgar se houve incompatibilidade entre a Emenda e texto original da Constituição de $88^{138}$.

Esse posicionamento não é alheio a críticas, na medida em que fragiliza o governo democrático, estabelecendo uma verdadeira ditadura do constituinte de 88 sobre a soberania contemporânea. Além do mais, os parâmetros de controle que o STF utiliza possuem conteúdo impreciso e altamente manipulável, como é o caso das cláusulas pétreas ${ }^{139}$ e das normas que perfazem o chamado núcleo intangível da Constituição.

É de difícil construção lógica o controle de constitucionalidade das emendas constitucionais, na medida em que elas são criadas para se incorporarem à Constituição e fiscalizá-las com base nos parâmetros constitucionais, portanto, seria como julgá-las contra si mesmas. Isso somente é possível tecnicamente, se for adotada uma hierarquia entre o texto original e as alterações posteriores, que, então, poderão ter sua compatibilidade aferida. Ocorre que essa supremacia do texto original não é totalmente esposada pela Carta de 88 , exceto no que tange às cláusulas pétreas, estas sim criando limites às emendas, ainda que de forma elástica. Não é o caso do controle de constitucionalidade de emendas por violação às demais normas constitucionais, como o direito à igualdade, a proporcionalidade, a dignidade da pessoa humana (as duas últimas sequer estão no Texto Magno), fruto de criação jurisprudencial que confere amplíssimos poderes ao STF na determinação daquilo que a Constituição é, foi e deverá ser.

Se imaginarmos a Constituição como as regras de um jogo em que diversos jogadores desempenham cada um seu papel, o Supremo Tribunal Federal não só executa suas regras mas também determina quando elas podem ser alteradas, conferindo-lhe uma supremacia sobre os demais jogadores.

O Supremo Tribunal Federal se posiciona, portanto, na delicada (ou indesejável) situação de fiscalizar todas as normas do país, inclusive aquelas a que ele deve obedecer, na medida em que é o ente que interpreta definitivamente o sentido das normas constitucionais e suas emendas, o que certamente causa preocupação sob a ótica da separação e harmonia entre os poderes.

\footnotetext{
${ }^{138}$ Esse posicionamento foi tomado na ADI 829 e seguido desde então.

139 Art. 60, CF (...)

$\S 4^{\circ}$ - Não será objeto de deliberação a proposta de emenda tendente a abolir:

I - a forma federativa de Estado;

II - o voto direto, secreto, universal e periódico;

III - a separação dos Poderes;

IV - os direitos e garantias individuais.
} 
Em adição, o controle exercido pelo Supremo Tribunal Federal, além de abranger praticamente todo e qualquer ato normativo expedido no país, ainda pode se alicerçar sobre múltiplos parâmetros normativos elásticos e manipuláveis, o que se transforma em um fértil terreno para o ativismo judiciário.

Todo esse poder ainda foi expandido com a edição da Lei 9882-99, que regulamentou a ADPF (Arguição de Descumprimento de Preceito Fundamental), prevista no art. $102, \S 1^{\circ}, \mathrm{CF}$, que tem por escopo "evitar ou reparar lesão a preceito fundamental, resultante de ato do poder público" 140 , além de permitir o controle de constitucionalidade de atos pré-constitucionais, seja na esfera federal, estadual ou municipal.

Não bastasse o STF ter o poder de anular toda e qualquer espécie normativa expedida em âmbito nacional, estadual ou municipal realizados sob a égide da Constituição de 1988, ele pode também fiscalizar todos aqueles que foram expedidos anteriormente, assim como os atos do poder público que violam "preceito fundamental", não havendo qualquer delimitação normativa do que essa expressão quer dizer.

Não há dúvidas de que o poder do Supremo Tribunal Federal é amplíssimo e uma das causas principais para as acusações de ativismo que rondam a Corte, uma vez que ele pode modificar praticamente todo ato normativo que quiser sem ter parâmetros precisos para tanto.

Deve ser levado em consideração, entretanto, que a maior parte dessas faculdades lhe foi conferida pelos Poderes representativos, tanto o Poder Constituinte de 88 quanto os Poderes Legislativos e Executivos posteriores.

Foram esses Poderes que ampliaram as faculdades do Supremo Tribunal Federal pós-88, não só em relação à amplitude de controle das normas, mas também à forma como ele pode ser exercido. Nesse caso, citamos, ad exemplum, os instrumentos processuais previstos na Lei 9868-99, que regulamenta a ADI, conferindo ao Supremo a possibilidade de atribuir diversos efeitos às suas decisões, ex tunc, ex nunc ou pro futuro, de acordo com aquilo que ele considera como "razões de segurança jurídica ou excepcional interesse social". ${ }^{141}$ Muitas vezes, tais prerrogativas colocam o julgador em situações constrangedoras, como ocorre nas lides tributárias em que a decisão de

\footnotetext{
${ }^{140}$ Art. $1^{\mathrm{o}}$ da Lei 9882-99: “A arguição prevista no $\S 1^{\mathrm{o}}$ do art. 102 da Constituição Federal será proposta perante o Supremo Tribunal Federal, e terá por objeto evitar ou reparar lesão a preceito fundamental, resultante de ato do Poder Público".

${ }^{141}$ Art. 27 da Lei 9868-99: "Ao declarar a inconstitucionalidade de lei ou ato normativo, e tendo em vista razões de segurança jurídica ou de excepcional interesse social, poderá o Supremo Tribunal Federal, por maioria de dois terços de seus membros, restringir os efeitos daquela declaração ou decidir que ela só tenha eficácia a partir de seu trânsito em julgado ou de outro momento que venha a ser fixado".
} 
inconstitucionalidade de um tributo tem repercussão de bilhões nos cofres públicos de acordo com seus efeitos serem retroativos ou não, o que sempre levantará dúvidas sobre a posição "política" do julgador pró-fisco ou pró-contribuinte. ${ }^{142}$

Outrossim, de acordo com a mesma lei federal, o STF pode expedir sentenças aditivas por meio da "interpretação conforme a Constituição"143, em que sua decisão tanto pode anular uma lei como também dizer qual deve ser a sua correta interpretação, adotando um dentre vários sentidos normativos possíveis, ou criando um novo, de modo que a lei fique de acordo com a Constituição.

Para complementar o quadro de superpoderes do Supremo Tribunal Federal, é preciso mencionar a recém-criada Súmula Vinculante, que permite a edição de enunciados normativos acerca da interpretação reiterada de dispositivos constitucionais. Trata-se de uma competência que tem sido utilizada com certa frequência pelo STF e gerado muitas controvérsias, já que ele a tem empregado não só para interpretar normas já existentes, mas criar novos direitos e institutos jurídicos, como é caso da súmula do nepotismo e do uso de algemas. ${ }^{144}$

Esses poderes imensos do Supremo Tribunal Federal não passaram despercebidos pela doutrina, que ora os aplaude, ora os critica. Fato lamentável, entretanto, é a existência de diversas ações na própria Corte que questionam a constitucionalidade de alguns desses poderes, como a modulação de efeitos ${ }^{145}$ e a regulamentação da $\operatorname{ADPF}^{146}$, que até o momento não foram julgadas, mas a Corte já os aplicou em casos concretos.

Trata-se de uma grave violação à questão de ordem que não pode ser prestigiada em um ordenamento jurídico que preza pela unidade e coerência. Por imperativo lógico,

\footnotetext{
${ }^{142}$ A modulação de efeitos é constantemente requerida pela União nas lides em que ela sofre reveses, como foi o caso do julgamento de inconstitucionalidade do FUNRURAL no RE 363.852.

143 Art. 28 da Lei 9868-99 (...) "Parágrafo único. A declaração de constitucionalidade ou de inconstitucionalidade, inclusive a interpretação conforme a Constituição e a declaração parcial de inconstitucionalidade sem redução de texto, têm eficácia contra todos e efeito vinculante em relação aos órgãos do Poder Judiciário e à Administração Pública federal, estadual e municipal”.

${ }^{144}$ Súmula Vinculante n. 11: "Só é lícito o uso de algemas em casos de resistência e de fundado receio de fuga ou de perigo à integridade física própria ou alheia, por parte do preso ou de terceiros, justificada a excepcionalidade por escrito, sob pena de responsabilidade disciplinar, civil e penal do agente ou da autoridade e de nulidade da prisão ou do ato processual a que se refere, sem prejuízo da responsabilidade civil do Estado". Súmula Vinculante n. 13: "A nomeação de cônjuge, companheiro ou parente em linha reta, colateral ou por afinidade, até o terceiro grau, inclusive, da autoridade nomeante ou de servidor da mesma pessoa jurídica investido em cargo de direção, chefia ou assessoramento, para o exercício de cargo em comissão ou de confiança ou, ainda, de função gratificada na administração pública direta e indireta em qualquer dos Poderes da União, dos Estados, do Distrito Federal e dos Municípios, compreendido o ajuste mediante designações recíprocas, viola a Constituição Federal.!

${ }^{145}$ As ADIs $2154-2$ e 2258-0 questionam a constitucionalidade do art. 27 da Lei 9868-99.

${ }^{146}$ A ADI 2231 questiona a constitucionalidade da regulamentação da ADPF realizada pela Lei 9882-99.
} 
deveria ter sido julgada, primeiramente, a constitucionalidade do instituto jurídico, para depois utilizá-lo.

Por fim, ressalta-se que os poderes do Supremo Tribunal Federal tornaram-se tão amplos que não são raras as confusões sobre qual forma de impugnação judicial é cabível em determinado caso, o que ocorre, por exemplo, nas inúmeras convolações de ADPF em $\mathrm{ADI}$, sem que haja um critério rigoroso para tanto, já que ainda não se afirmou quais são as hipóteses de cabimento da ADPF após mais de dez anos de sua existência.

Nos Estados Unidos, por sua vez, embora o judicial review tenha um amplo aspecto de incidência, podendo ser questionadas as leis federais, estaduais e municipais, ele não tem a mesma amplitude e características que o modelo de controle de constitucionalidade do Brasil.

A primeira distinção fundamental é sobre a ausência de controle abstrato de constitucionalidade, o que reduz significativamente a possibilidade de modificação ou anulação de leis pela Suprema Corte. Além do mais, o controle abstrato tem um modo especulativo de pensar que o aproxima dos debates parlamentares, tornando-o mais suscetível às incursões ativistas. Por seu turno, o controle difuso tem como pressuposto a existência de uma lide concreta, o que confere maior visibilidade e particularização sobre os possíveis efeitos de uma lei, delimitando melhor o objeto em análise. Essa posição tem sido reiteradamente afirmada por meio das justiciability doctrines.

Outra distinção importante é quanto às ações existentes para se alcançar a Corte. No Brasil, há uma confusão muito grande sobre a forma de se impugnar determinada norma, sendo que ela pode ser questionada tanto abstratamente por meio de uma ADI ou $\mathrm{ADPF}$, rebatida pela União por meio de uma $\mathrm{ADC}$, ou questionada em uma relação jurídica concreta por meio de diversos recursos, como o Recurso Extraordinário, a Reclamação, o Mandado de Segurança ou o Mandado de Injunção. Todas essas ações podem tramitar em conjunto sem que seja estabelecida uma necessária conexão processual sobre elas, podendo causar graves incoerências na interpretação da mesma lei.

Nos Estados Unidos, a legislação e a jurisprudência são mais claras, não sendo difícil saber qual é o recurso cabível em determinada situação. $\mathrm{Na}$ quase totalidade dos casos que chegam à Suprema Corte, o recurso empregado é o writ of certiorari.

No que tange às espécies normativas que podem sofrer controle pela judicial review, é importante ressaltar que nunca na história dos Estados Unidos a Suprema Corte realizou fiscalização sobre as Emendas Constitucionais, o que revela uma importante contenção da Corte e respeito pelo Congresso. Embora haja discussão na doutrina sobre a 
eventual possibilidade teórica de sua existência ${ }^{147}$, nos poucos casos em que isso foi aventado a Corte afirmou a constitucionalidade da Emenda, como ocorreu em Leser $v$. Garnett. ${ }^{148}$

Nos Estados Unidos, a Corte não adota explicitamente a teoria do Poder Constituinte Originário e Derivado, respeitando com maior vigor a soberania constitucional das leis expedidas pelo Congresso e sua representatividade democrática ${ }^{149}$, ainda que tenha grande apreço pela interpretação originalista baseada na vontade dos Founding Fathers.

Por fim, importa ressaltar que não há qualquer instituto jurídico nos Estados Unidos que seja próximo à Súmula Vinculante ou à ADPF, sendo que o Congresso dificilmente daria tal poder amplo e ilimitado à Suprema Corte, além de ambas serem contrárias às justiciability doctrines.

Concluímos, portanto, que, no que tange a extensão do poder de controle de constitucionalidade, tanto no Brasil quanto nos Estados Unidos, seus órgãos judiciários supremos detêm o poder de anular e modificar significativa parcela dos atos normativos expedidos em cada país, muito embora no Brasil essa amplitude seja consideravelmente maior em razão do controle sobre as Emendas Constitucionais e das ações de fiscalização abstrata, que conferem um poder quasi-parlamentar de revogação e promulgação de novas leis, com base nos instrumentos processuais existentes, em especial, a modulação de efeitos, as sentenças aditivas e a súmula vinculante.

2.3 Os processo de seleção de seus membros

147 O'BRIEN, David M. Constitutional law and politics. vol. 2. $6^{\text {a }}$ ed. New York: W.W. Norton \& Company, 2005. p. 89-91

${ }^{148}$ No caso Leser v. Garnett foi questionada, dentre outros temas, a constitucionalidade da Emenda Constitucional n. 19, que proibiu a restrição ao voto baseada no gênero. A Suprema Corte asseverou que a Emenda era constitucional e não havia motivos para a manutenção das restrições da Constituição de Maryland que determinava o direito ao voto exclusivamente aos homens, afastando as mulheres do pleito.

149 Deve ser mencionada a elevada legitimidade democrática do complexo sistema de aprovação das Emendas Constitucionais nos Estados Unidos, pois ela deve ser aprovada por 2/3 de cada casa do Congresso Nacional (House of Representative e Senado Federal), e posteriormente, por 3/4 das Assembléias Estaduais. Outra forma de promulgação de Emendas jamais foi utilizada e envolve a conclamação de uma Convenção do Congresso Nacional por $2 / 3$ dos Estados, que deverá aprovar a emenda e depois submetê-la para retificação pelos Estados. 


\subsubsection{Forma de composição e requisitos}

Tanto no Brasil quanto nos EUA, os órgãos judiciários supremos têm suas vagas preenchidas por meio de indicação presidencial, condicionada à aprovação da maioria do Senado Federal ${ }^{150}$. No Brasil, são onze cargos de Ministros do Supremo Tribunal Federal $^{151}$, enquanto, nos EUA, são nove cargos de justices da Suprema Corte ${ }^{152}$, sendo oito de associate justices e um de chief justice, este último exercendo a função de presidente.

Não se trata de um sistema alheio a críticas, em que são constantes os ataques quanto à forte vinculação do nomeante com a figura do Presidente da República. Alegadamente, isso coloca em xeque a independência necessária para o exercício do futuro cargo, no qual, inevitavelmente, o nomeado julgará ações em que o Presidente tem interesse imediato.

São variadas as propostas doutrinárias e legislativas brasileiras de alteração dessa fórmula $^{153}$, a maioria sugerindo um sistema misto de nomeação entre o Presidente, o Congresso Nacional e outros órgãos (como o Poder Judiciário e a Ordem dos Advogados do Brasil). Todas aludem para a importância de uma composição plural do Tribunal, afastando a influência marcante do Poder Executivo Federal.

Nenhuma delas, entretanto, parece ter tido força suficiente para emplacar uma mudança legislativa até o momento.

Quanto à nomeação do Presidente da Corte, nos EUA o chief justice passa pelo procedimento comum de indicação do Presidente da República seguida de aprovação pelo Senado, independente do nomeante ser um atual associate justice ou não. No Brasil, o Presidente do STF é eleito dentre um de seus integrantes e por voto da maioria absoluta de

\footnotetext{
${ }^{150} \mathrm{Na}$ Constituição brasileira, ver art. 101, § único, CF. Na Constituição dos EUA, ver Artigo 2, seção 2, cláusula 2.

151 Art. $101, \mathrm{CF}$.

${ }^{152}$ Esse número mantém-se fixo desde o Judiciary Act of 1869.

${ }^{153}$ Em especial, fazemos menção ao trabalho de MORAES, Alexandre de. Jurisdição constitucional e tribunais constitucionais: garantia suprema da Constituição. São Paulo: Atlas, 2000.
} 
seus próprios membros (art. 12, RISTF), sendo que, tradicionalmente, escolhe-se, por unanimidade, o mais antigo da Casa que ainda não foi Presidente. ${ }^{154}$

$\mathrm{Na}$ Corte brasileira, seu Presidente tem mandato de dois anos, sendo vedada a recondução (art. 12, RISTF), enquanto nos EUA o mandato do chief justice é vitalício assim como o dos demais membros.

Cumpre ressaltar que, além do processo de nomeação descrito, há, nos EUA, a possibilidade do recess appointment, consubstanciado no poder do Presidente da República de nomear direta e provisoriamente um justice, durante o recesso do Senado e independente de aprovação deste último.

Trata-se de uma prerrogativa decorrente do artigo $2^{\circ}$ da Constituição e de raro exercício na história dos EUA, já que pode ser entendida como um desrespeito ao Senado. Além do mais, após o retorno de seu recesso, o órgão legislativo deverá votar a indicação em caráter definitivo, podendo rejeitá-la em revide.

Algumas circunstâncias, como o excesso de processos na Corte ou o julgamento pendente de uma causa importantíssima, podem indicar a necessidade urgente de uma nomeação sem colocar em atrito os Poderes, como parece ter ocorrido no caso do recess appointment do chief justice Earl Warren, após o ataque cardíaco sofrido pelo chief justice Fred Vinson em 1953, pendente o julgamento de Brown.

Quanto aos requisitos para nomeação, a Constituição estadunidense não contempla qualquer um deles, enquanto a brasileira traz cinco: i) ser brasileiro nato (art. 12, § 3 , IV, $\mathrm{CF}$ ); ii) ser cidadão no pleno gozo dos direitos políticos (art. 101,CF); iii) ter mais de $35 \mathrm{e}$ menos de 65 anos de idade (art. 101, CF); iv) possuir notável saber jurídico ${ }^{155}$ (art. 101, $\mathrm{CF})$; v) ter reputação ilibada (art. 101,CF). ${ }^{156}$

No que tange ao número de membros, há variação histórica em ambas as Cortes, sendo que, atualmente, são onze membros no Brasil e nove nos EUA.

Quanto ao mandato exercido pelos membros da Corte, não há um período fixo préestabelecido nos dois países, sendo que, nos EUA, o mandato é vitalício sem limitação

\footnotetext{
${ }^{154154}$ A eleição do Presidente do STF pelos próprios membros da Corte é uma herança histórica que advém desde a República com o Decreto n. 848 de 11 de outubro de 1890 (editada pelo Governo Provisório), cujo art. 11 dispunha: "Os membros do Supremo Tribunal Federal elegerão dentre si um presidente e um vicepresidente, que servirão durante tres annos, podendo ser reeleitos. Em seus impedimentos temporarios será o presidente substituido pelo vice-presidente, e este pelo membro mais idoso do tribunal."

${ }^{155}$ Trata-se de um requisito subjetivo, conforme a doutrina brasileira. Há poucas vozes advogando pela exigência implícita de graduação em direito, o que não é esposado pela maioria (embora na prática, seja praticamente impossível a nomeação de um Ministro que não seja formado em direito dada a elevadíssima exigência técnica hodierna). Ver a este respeito, MORAES, op. cit. p. 545-546.

${ }^{156}$ Também se trata de um requisito de índole subjetiva, embora haja uma certa concordância na doutrina quanto a graves violações de cunho criminal ou por responsabilidade que afetariam a reputação do nomeado.
} 
temporal e, no Brasil, embora também vigore a garantia da vitaliciedade, ela é mitigada pela aposentadoria compulsória aos 70 anos.

Há críticas na doutrina estadunidense quanto à regra da vitaliciedade absoluta, relatando mandatos longuíssimos e episódios lamentáveis de juízes enfermos e com a capacidade intelectual reduzida, ou simplesmente pouco motivados, que não abandonavam seus cargos. Em especial, aduzem para a legislação do início do século que não previa o pagamento de aposentadoria aos justices, motivo pelo qual eles trabalhavam na Corte até a morte, literalmente ${ }^{157}$.

No Brasil, embora a aposentadoria garanta a saída compulsória dos Ministros, isto não retira o desconforto de que, em tese, um mandato pode durar até trinta e cinco anos (sendo que na história do Tribunal, alguns chegaram próximos a três decênios ${ }^{158}$ ), além de não haver mecanismo de retirada de membros enfermos e pouco motivados, o que parecer ser o real problema.

Uma crítica comum em ambos os países é a atribuição de onerosas funções para além do já desgastante e intenso trabalho nas Cortes. Nos EUA, os justices são lotados como Circuit Judges ${ }^{159}$, onde passam pequena parte do ano realizando julgamentos em tribunais federais recursais, com o fito de alinhar toda a jurisdição federal à Suprema Corte.

No Brasil, o presidente do Supremo Tribunal Federal é também presidente do Conselho Nacional de Justiça (art. 103-B, $\S 1^{\circ}, \mathrm{CF}$ ), enquanto outros três Ministros devem compor o Tribunal Superior Eleitoral (art. 119, I, a, CF).

Por fim, cumpre mencionar que a remuneração dos juízes em ambos os países é tratada com muita seriedade em razão das responsabilidades que advêm do cargo, buscando-se um salário equilibrado que não seja irrisório a ponto de menosprezar as funções e comprometer a imparcialidade, tampouco seja excessivamente elevado e se torne a fonte primeira de atração para a Corte.

\footnotetext{
${ }^{157}$ Unah relata o caso de Ward Hunt que sofreu um derrame e ficou totalmente paralizado de um lado do corpo e não se retirava da Corte por ausência de pensão. Situação diversa de Charles Whittaker que tinha dificuldades em tomar decisões difíceis e acabou tendo um ataque de nervos. Por sugestão de Warren, se aposentou. UNAH, Isaac. op. cit. p. 43

${ }^{158}$ O Ministro Herminio do Espirito Santo permaneceu na Corte durante 29 anos, 11 meses e 24 dias e faleceu no cargo em 1924. O Ministro André Cavalcante também faleceu no cargo em 1927, aos 93 anos de idade, após 29 anos e 8 meses na Corte. MELLO FILHO, José Celso de. Notas sobre o Supremo Tribunal (Império e República). $2^{\mathrm{a}}$ ed. Brasília: Supremo Tribunal Federal, 2007. Disponível em < http://www.stf.jus.br/arquivo/cms/sobreStfConhecaStfCuriosidadeStf/anexo/NotasInformativasEletronica16 1007.pdf>. Acesso em 30.11.2011. p. 18.

${ }^{159}$ US Code, título 28, seção 42.
} 
No Brasil, atualmente, os vencimentos dos Ministros do Supremo Tribunal Federal giram em torno de vinte e seis mil e setecentos reais mensais (não considerados os descontos e eventuais adições decorrentes de vantagens pessoais, adicionais ou gratificações), enquanto, nos EUA, em 2009, e de acordo com BAUM ${ }^{160}$, foram pagos \$ 213,900 para cada associate justice e $\$ 223,500$ para o chief justice, todos em valores anuais.

Cumpre salientar que a remuneração do Ministro do Supremo Tribunal Federal é considerada o teto da remuneração do funcionalismo público brasileiro (art. 37, XI, CF), sendo utilizada como parâmetro para diversos outros cargos. Tal fato não é irrisório, pois qualquer modificação no salário dos Ministros gera um efeito cascata de proporções nacionais e bilionárias, colocando em constante conflito as pretensões de reajuste ou elevação salarial e os cofres do governo.

2.3.2 Os atores que participam da escolha: o Poder Executivo, as associações classistas, os grupos de interesse e o Senado Federal

Como visto, em ambos os países, a forma de composição dos órgãos judiciários supremos é bastante similar.

Isso não quer dizer que o preenchimento das vagas se dê pelas mesmas razões, tendo em vista a existência de diversos fatores no processo de seleção que influenciam significativamente a escolha final.

Nessa seara, a literatura estadunidense é farta, especialmente no âmbito das ciências políticas, que investigam os diversos atores que operam junto ao polo do poder e buscam satisfazer seus interesses.

Tendo em vista que uma das principais causas do ativismo é de origem pessoal, ou seja, é decorrente da afirmação das convicções do juiz em desrespeito à lei, é mister conhecer quem são esses juízes e como foram selecionados para a Corte.

Afinal de contas, se o ativismo é um fenômeno indesejável - como a maioria alega -, como é que esses juízes ativistas não foram barrados no processo de seleção? Há deficiências no processo? Os poderes políticos e a sociedade foram, de alguma forma,

${ }^{160}$ BAUM, Lawrence. op. cit. p. 12. 
ludibriados pelo candidato? Existe algum grupo de pressão ou interesse econômico ditando as escolhas veladamente? $\mathrm{Ou}$ o procedimento estabelecido permite $\mathrm{o}$ conhecimento suficiente do nomeado a ponto de as opções serem conscientes?

Para responder a essas perguntas, faremos uma análise concisa dos principais atores que permeiam o processo de seleção dos juízes, tomando como base a doutrina estadunidense que elenca o Poder Executivo, o Senado, as associações classistas e os grupos de interesse.

No âmbito do Poder Executivo, participam ativamente como principais conselheiros do Presidente, o Departamento de Justiça e o White House Office of Legal Policy, que realizam investigações maciças das posições jurídicas e ideológicas dos candidatos, seja por meio da leitura dos documentos jurídicos por ele escrito (sentença, recurso, artigo, livro, etc), seja pela arguição de pessoas a ele próximas.

Também participa junto ao Executivo, o FBI (Federal Bureau of Investigation), examinando a vida pregressa do candidato e procurando qualquer fato que possa macular sua imagem e idoneidade.

Esses órgãos não atuam de forma acriteriosa, pois realizam sua pesquisa de acordo com as diretrizes fornecidas pelo Presidente. Isso é de salutar compreensão, pois a indicação presidencial não se faz apenas por critérios técnico-jurídicos advindos de relatórios de conselheiros. Esse é apenas um dos critérios presentes no complexo processo decisional.

Episódios históricos, como a oposição da Corte de Warren às leis do New Deal, demonstraram a importância do Judiciário na agenda política nacional, sendo fundamental que o Presidente não encontre resistência judicial para concretizar os seus planos. Sendo assim, cada Presidente tem a sua agenda política e utiliza todos os seus poderes para que os Tribunais estejam alinhados com ela, sendo a Suprema Corte uma peça-chave.

Por isso, a escolha de um nome é tema de primeira relevância na política interna, e está adstrita a critérios muitas vezes circunstanciais estabelecidos pelo Presidente. Por exemplo, quando Nixon foi eleito e teve a oportunidade de indicar um membro da Suprema Corte, dentre seus requisitos estava que os candidatos tivessem uma ideologia de autocontenção e proviessem dos estados do sul, seu reduto eleitoral. ${ }^{161}$

Esses critérios podem variar significativamente e não há uma regra sobre quem poderá ser nomeado. A indicação pode ser o resultado de um longo exame de inúmeros

${ }^{161}$ UNAH, Isaac. op. cit. p. 62. 
juristas, pautada pela sua capacidade e notoriedade, como a simples escolha de uma pessoa íntima e de confiança, como o foi o caso do Presidente Bush e a indicação de Miers.

O uso político estratégico também não está descartado, como ocorreu na indicação de John Marshall, após a derrota de Adams para reeleição nas conturbadas eleições de 1801, ocasião em que o último decidiu direcionar grandes expoentes de seu Partido Federalista no Poder Judiciário, encontrando ali um reduto para a manutenção de suas ideologias. $^{162}$

O Presidente, aliás, não decide sozinho. Líderes do partido, Senadores e Congressistas dialogam com ele, já que é preciso averiguar a aceitação do nome e suas chances de aprovação posterior no Senado. É altamente embaraçoso para o Presidente ter que enfrentar uma rejeição, posto que diminui sua credibilidade e prestígio perante os Poderes.

Uma outra fonte de influência é o próprio candidato. A história registra a existência de autopromoções para o cargo, principalmente por ex-políticos que, cientes dos bastidores do poder, realizam campanha própria para a Suprema Corte com maior facilidade.

É o caso de William Howard Taft, que praticamente se autonomeou justice, dada sua condição de ex-presidente - o que lhe garantia grande prestígio e influência pessoal. A nomeação de ex-políticos, tanto no Brasil, quanto nos EUA, não é fato raro como se mostrará mais adiante.

No Brasil, não encontramos estudos sobre o modo como os Presidentes escolhem os candidatos, embora não haja razão para que ele seja muito distinto.

A despeito de nosso desconhecimento sobre eventuais relatórios internos do Executivo federal sobre possíveis candidatos, há notícia frequente na mídia sobre diálogos entre o Presidente e pessoas próximas que lhe fornecem dados e buscam influenciar sua opinião. Essas pessoas podem variar de Ministros de Estado, Senadores, cúpula partidária, Ministros do Supremo Tribunal Federal ${ }^{163}$, e até familiares mais íntimos. ${ }^{164}$

\footnotetext{
${ }^{162}$ Ver a respeito, ACKERMAN, Bruce. op. cit.

${ }^{163}$ Não é raro um Ministro do Supremo Tribunal Federal ser consultado acerca de um futuro membro da Corte ou indicar um nome. Por exemplo, COSTA, Raimundo. Fux entra na lista de padrinhos que disputam indicação ao STF. Valor Econômico. Disponível em $<$ http://www.valor.com.br/politica/1040820/fux-entrana-lista-de-padrinhos-que-disputam-indicacao-ao-stf>. Acesso em 8.12.2011.

${ }^{164}$ O jornal Valor Econômico, por exemplo, assevera que houve influência do ex-marido e filha da Presidente da República na a escolha da Minstra Rosa Weber do TRT para o cargo de Ministra do Supremo Tribunal Federal. BASILE, Juliano. Dilma escolha Rosa Weber, do TST, para o Supremo. Valor
} 
Quanto às associações classistas, a doutrina estadunidense relata uma forte atuação da ABA (American Bar Association), que possui um ranking de avaliação de cada um deles, baseado em três critérios: competência profissional, temperamento judicial e integridade. Apesar do subjetivismo que tais critérios possam denotar, o fato é que a ABA trata-os com extrema seriedade e realiza um minucioso trabalho envolvendo muitos profissionais em âmbito nacional.

Os membros do Standing Comittee on Federal Judiciary da ABA realizam inúmeras (até centenas) entrevistas sigilosas com pessoas ligadas ao candidato ou que tenham qualquer informação relevante sobre ele. Grupos de acadêmicos avaliam todos os documentos jurídicos por ele escrito ao longo de sua carreira, avaliando seu nível de conhecimento por área. Além do mais, outro grupo de advogados de alto escalão também examina suas peças processuais e fornece elementos para a avaliação.

Ao final, o comitê julga o candidato como well qualified, qualified ou not qualified. $^{165}$

O ranking da $\mathrm{ABA}$ tem sido realizado há mais de cinquenta anos e goza de prestígio nos EUA, embora não possa ser considerado como determinante na nomeação. $\mathrm{O}$ julgamento da $\mathrm{ABA}$, mesmo sendo elaborado seriamente por um time de experts e com parâmetros bem definidos, ainda sofre críticas de interesses classistas, o que compromete sua idoneidade.

Isso não significa que o ranking e os relatórios não tenham peso nas escolhas, pois eles exigem conhecimentos técnicos profundos e atuação profissional exemplar do candidato, elevando o nível das escolhas e podendo causar embaraço caso um fato desonroso seja revelado.

A Ordem dos Advogados no Brasil não realiza um ranking sobre os candidatos, tampouco um relatório minucioso sobre eles. Até os limites de nosso conhecimento, suas manifestações são restritas às opiniões de seus membros, diálogos de bastidores, ou uma simples nota oficial.

Outras associações classistas que, pelo menos no Brasil, aparentam participar desse processo, são as entidades que reúnem os magistrados brasileiros. Embora não tenhamos encontrado uma literatura específica sobre seu desempenho nessa seara, há notícias frequentes em jornais relatando a manifestação de representantes dessas entidades,

Econômico. Disponível em $<$ http://www.valor.com.br/politica/1086370/dilma-escolhe-rosa-weber-do-tstpara-o-supremo>. Acesso em 8.12.2011.

${ }^{165} \mathrm{Na}$ tradução literal seria: "bem qualificado, qualificado ou não qualificado". 
recomendando determinados nomes. A par das associações, é possível encontrar membros da magistratura que gozam de certa visibilidade e expressam sua opinião própria sobre eventuais candidatos.

O terceiro ator de grande importância nos EUA são os grupos de interesse, cuja presença no processo de nomeação tem crescido nos últimos anos, sendo constatada a existência de forte pressão e campanhas milionárias em favor de candidatos ao cargo.

Baum revela que grupos liberais teriam despendido entre doze e quinze milhões contra o nome de Robert Bork em 1987, pois era considerado um ferrenho conservador. ${ }^{166}$ Mais recentemente, Unah cita os dados do Brennan Center de que movimentos liberais e conservadores teriam gasto, cada um, pouco mais de um milhão de dólares somente em anúncios televisivos durante o processo de nomeação do justice Samuel Alito em $2006 .{ }^{167}$

Esse fenômeno não é novo, tendo profundas raízes históricas, como mostra a rejeição do juiz John Parker por indicação do Presidente Hoover em 1930, em razão da oposição da NAACP (National Association for the Advancement of Colored People) e de grupos trabalhistas, que não simpatizavam com o teor de suas decisões na Corte de Apelações do Quarto Circuito. ${ }^{168}$

$\mathrm{Na}$ história mais recente da Corte brasileira, não encontramos literatura sobre os grupos de pressão durante o processo de nomeação dos Ministros do Supremo Tribunal Federal, sendo discutível o grau de influência que eles exercem. Um dos fatores que comprometem o estudo é a inexistência de legislação que preveja regras claras e transparentes de atuação desses grupos, fazendo com que a fonte primária de conhecimento seja informal ou jornalística.

Por fim, para dar a palavra final no processo de seleção, temos o Senado Federal.

$\mathrm{Na}$ sistemática procedimental brasileira, o nome escolhido pelo Presidente da República é submetido ao crivo preliminar da Comissão de Constituição e Justiça, ocasião em que o candidato será sabatinado publicamente e deverá responder as perguntas dos Senadores (art. 101, II, i, RISF). Sendo aprovado por essa Comissão, o nome é enviado para votação, em plenário, exigindo-se quorum de maioria absoluta de seus membros para aprovação (art. 101, § único, CF e 288, III, d, RISF).

Nos EUA, o nome indicado pelo Presidente é analisado pelo Senate Judiciary Comittee, onde são arguidos o candidato e qualquer outra pessoa que tenha conhecimentos

\footnotetext{
${ }^{166}$ BAUM, Lawrence. op. cit. p. 31.

${ }^{167}$ UNAH, Isaac. op. cit. p. 76.

${ }^{168}$ UNAH, Issac. $i b$. p. 76.
} 
relevantes sobre ele. Ocorrendo aprovação pelo comitê, o nome é submetido à deliberação final do Senado pela maioria de seus membros.

Muito embora os procedimentos sejam similares, a postura de seus membros não o é.

A experiência demonstra que o Senado Federal brasileiro tem atuado de forma muito mais tímida do que seus pares estadunidenses, não demonstrando disposição para contestar veementemente as escolhas presidenciais.

Em toda a história constitucional brasileira, apenas cinco nomes foram rejeitados, nenhum sob o manto da atual Constituição ${ }^{169}$, enquanto nos EUA, a proporção de rejeição é de uma a cada cinco indicações, o que quer dizer que 29 candidatos sofreram reveses dentre 152 indicados em toda a história. ${ }^{170}$

Embora seja um indicativo importante, o maior número de rejeições, por si só, não quer dizer que o Senado seja mais atuante e independente. Existem inúmeras questões que devem ser consideradas em relação a esses dados, como por exemplo, a habilidade política do Presidente em escolher um nome que goze de amplo prestígio dentre os Senadores, ou a detenção de uma maioria governista no Senado que aprovará a escolha independente de qual ela seja.

No caso brasileiro, todavia, nos parece que a existência de um bloco monocolor entre o Executivo e Legislativo ${ }^{171}$ (decorrência, dentre outros, do presidencialismo de coalização), aliado ao forte desgaste e estado quase letárgico do Parlamento nacional, denotam a pouca força desse órgão político no processo de escolha, não nos parecendo que ele detenha autonomia suficiente para contrapor o Poder Executivo, embora tenha prerrogativas claras para tanto.

Um caso emblemático que permite comparações diretas é o da indicação de advogados diretamente vinculados à pessoa do Presidente.

Dentre nós, uma das nomeações mais polêmicas em tempos recentes foi a do Ministro José Carlos Dias Toffoli, uma vez ele havia sido advogado pessoal do Presidente Luis Inácio Lula da Silva e de seu partido (o Partido dos Trabalhadores), durante a quase totalidade de sua carreira profissional. Isso não compromete a sua qualidade técnica

\footnotetext{
169 Todos os candidatos foram rejeitados durante o governo de Floriano Peixoto (1891-1894) sendo eles: Barata Ribeiro, Innocêncio Galvão de Queiroz, Ewerton Quadros, Antônio Sève Navarro e Demosthenes da Silveira Lobo.

${ }^{170}$ BAUM, Lawrence. op. cit. p. 27. Dentre os 29 mencionados estão incluídos os casos em que houve a prematura retirada dos nomes após intensa oposição do Senate Judiciary Comitte.

${ }^{171}$ Sobre o tema ver e trabalho de Monica Herman Salem Caggiano, "A emergência do Poder Judiciário" (op. cit.).
} 
jurídica, mas influencia a sua inclinação ideológica, o que levantou dúvidas quanto a sua futura imparcialidade.

Embora tenha havido críticas nos meios de comunicação e por alguns Senadores durante a sabatina da Comissão de Constituição e Justiça, seu nome não enfrentou grande resistência e foi aprovado sem maiores dificuldades.

O mesmo não ocorreu nos EUA, quando George W. Bush indicou sua advogada Harriet Miers, em 2005, para o cargo de justice, o que foi prontamente rechaçado pelos Senadores, que não lhe deixaram outra opção senão desistir da candidatura. ${ }^{172}$

Conforme já asseverado, a questão aqui não é avaliar a competência técnica do candidato, pois esse é apenas um dos requisitos indispensáveis para o exercício de um dos mais elevados cargos de uma nação. O importante é verificar até que o ponto o Senado está disposto a pressionar o Executivo por uma indicação que não só atenda os requisitos do Presidente, mas os seus também.

As sabatinas mais recentes indicam que os Senadores brasileiros procuram muito mais conhecer o candidato e se familiarizar com eles, do que pressioná-los ou até constrangê-los, o que seria esperado daqueles que não concordam com o nome apresentado e desejam sua rejeição.

Além do mais, conforme já ressaltado, não parece que esteja solidificada a concepção nacional de que o Supremo Tribunal Federal integra o polo do poder e seus membros devem sofrer um minucioso escrutínio por parte das esferas políticas e também da sociedade, posto que diversos temas da agenda nacional fatalmente recairão nas mãos da Corte.

Nos próximos subcapítulos, aprofundaremos o tema e examinaremos alguns dos fatores que levam à aprovação de um candidato, em especial, sua ideologia, seu partido político e o fenômeno da symbolic representation.

2.3.3 Quem é escolhido para o órgão judiciário supremo de um país?

2.3.3.1 A questão da ideologia e do partidarismo

${ }^{172}$ BAUM, Lawrence. op. cit. p. 39. 
No primeiro capítulo, adotamos uma visão de ativismo como uma concepção difusa de exercício ilegítimo do poder judicial, em que o juiz toma decisões com base em suas convicções e ideologias pessoais, em detrimento dos termos da lei e da Constituição.

Para os fins de nossos estudos, utilizaremos o termo ideologia e convicções como sinônimos, designando todo o conjunto de valores, crenças e ideias que um sujeito possui, considerado em sua totalidade, isto é, abrangendo a esfera social, moral, econômica, política, religiosa, etc. ${ }^{173}$

Sendo certo que diversas normas constitucionais têm conteúdo aberto e valorativo, não há nada mais importante na construção de seu sentido do que a ideologia do intérprete, no caso, o juiz.

É fundamental conhecer suas convicções para poder prever seus julgamentos e tentar persuadi-lo. Um advogado, ao elaborar um recurso, deve considerar a quem ele é dirigido, de forma a escolher melhor seus argumentos e elevar suas chances de êxito.

Do mesmo modo, os Poderes Executivo e Legislativo devem considerar a inclinação ideológica dos juízes antes de criarem determinada política pública, posto que ela poderá ser questionada judicialmente e sucumbir. Mais ainda quando se trata da Suprema Corte, que tem a palavra final no seio do Poder Judiciário e conta com importantes prerrogativas e instrumentos processuais para modificar ou invalidar uma determinada política pública.

Nesse campo, sem sombra de dúvida, os Estados Unidos estão muito mais avançados do que o Brasil. São inúmeros os trabalhos acadêmicos e jornalísticos que examinam a vida e as ideologias dos justices, buscando um fiel retrato de quem eles são e como se comportam na Suprema Corte.

Não é à toa que o justice Anthony Kennedy já foi considerado como o "homem mais perigoso da América"174, em razão da atual divisão ideológica da Corte entre quatro liberais e quatro conservadores, tornando-o o decisive fifth vote (quinto voto decisivo).

A tendência na Suprema Corte, portanto, é que haja um equilíbrio ideológico com o voto de minerva de Kennedy, fazendo com que ele seja um dos justices mais cotejados da Corte.

\footnotetext{
${ }^{173}$ Buscamos apenas uma definição semântica coloquial do termo sem alusão a qualquer teoria filosófica. ${ }^{174}$ BAUM, Lawrence. op. cit. p. 1. Frase atribuída a um líder de grupo de interesse.
} 
Embora essa divisão entre liberais e conservadores não seja estanque e não se reflita em toda decisão, os estudos conferem boa margem de acuidade e significativos índices de acertos sobre o resultado de um julgamento.

Isso provém, em primeiro lugar de uma cultura ideológica mais bem definida. Podemos citar o caso do justice Antonin Scalia, que leciona e frequentemente escreve artigos sobre sua adoção à filosofia originalista, conferindo um material precioso sobre sua filosofia jurídica e política.

Tal fato confere uma boa dose de segurança quanto ao resultado de seus julgamentos, sendo quase impossível que ele espose uma decisão da Corte mais incisa sobre políticas públicas, como por exemplo, a legalização do aborto ou de drogas mais leves.

O que não quer dizer, contudo, que seus julgamentos sejam totalmente previsíveis, pois há sempre uma margem de risco entre as concepções abstratamente elaboradas e a decisão de um caso concreto, em que as circunstâncias fáticas podem conduzir o julgador a posições, aparentemente, divergentes.

As ideologias, ainda que expostas e bem elaboradas intelectualmente, não são aptas a criar um sistema de regras compreensivo de juízos de valor sobre toda a realidade jurídica e social.

Há também circunstâncias externas que influenciam a decisão do juiz e que não estão adstritas às suas convicções pessoais, mas referem-se a uma ponderação de sua posição como membro de órgão do poder que não age isoladamente, como é o caso da aceitação política e social da decisão, sua repercussão econômica, a possibilidade de reversão legislativa, etc.

Portanto a questão aqui não é de certeza quanto ao resultado de um julgamento e das posições dos julgadores, mas de seu grau de probabilidade.

Isso não ocorre no Brasil, onde não acreditamos que posições ideológicas bem definidas pelos Ministros. Não é possível afirmar que há conservadores, liberais, positivistas ou originalistas no STF, nem tanto em razão das controvérsias acadêmicas acerca desses conceitos, mas muito mais por conta da ausência de uma cultura nacional favorável a concepções filosóficas mais rígidas e dogmáticas. É quase impossível prever qual será a posição deles em determinado tema que, a princípio, teria respostas fáceis se houvesse uma definição ideológica mais rígida.

Um caso como o do reconhecimento da união homoafetiva, certamente seria julgado improcedente por um juiz conservador, positivista ou com fortes crenças 
religiosas, o que não ocorreu na votação da ADI 4277, apesar de alguns Ministros terem demonstrado essas características em outros julgamentos. Isto causa muita insegurança jurídica tanto na sociedade quanto nos poderes políticos, que não sabem qual caminho tomar em determinados assuntos delicados que podem vir a ser questionados judicialmente.

Em contraposição, na atual composição da Suprema Corte, há um claro viés de autocontenção e conservadorismo, resultado das reiteradas indicações republicanas dos últimos anos, que visavam preenchê-la com juízes que dessem fim à era do ativismo judicial desenvolvida pela Corte de Burger. Atualmente, tentar levar um tema como a legalização da eutanásia para a Suprema Corte é uma empreitada com pouquíssimas chances de sucesso.

Um aspecto que confere maior previsibilidade às decisões de um Tribunal e permite conhecer melhor a ideologia dos indicados é o critério de seleção utilizado. As últimas nomeações da Suprema Corte têm recaído apenas sobre juízes de carreira, pois suas convicções podem ser conhecidas por meio de seus julgados, tornando mais previsível a sua atuação na Corte. O mesmo não ocorre com causídicos públicos ou privados, que defendem os interesses de terceiros e nem sempre expressam suas próprias conviç̧ões.

Interessante a matéria veiculada pelo jornal Valor Econômico ${ }^{175}$, em 08 de novembro de 2011, que revelava a possível indicação da Ministra Rosa Maria Weber Candiota para o cargo de Ministra do Supremo Tribunal Federal, o que veio a se confirmar posteriormente. Um dos motivos para a escolha, segundo a matéria, foi a visão "social" do direito apresentada pela Ministra em várias decisões, afastando o legalismo estrito e flexibilizando algumas regras jurídicas em prol dos trabalhadores, o que certamente deve

\footnotetext{
${ }^{175}$ No texto veiculado pode-se ver os exemplos da visão "metajurídica" da Ministra: "O perfil profissional da ministra foi outro ponto favorável à escolha. Rosa Maria costuma considerar a repercussão social e econômica de suas decisões no TST. Um exemplo foi quando votou a favor da concessão de direitos para aposentados, mesmo ultrapassado o prazo de prescrição. Ela também foi favorável aos direitos da gestante quando a gravidez for revelada durante aviso prévio. Para a ministra, os efeitos sociais ou metajurídicos devem ser considerados pelo juiz ao julgar casos de maior repercussão." BASILE, Juliano. Dilma escolha Rosa Weber, do TST, para o Supremo. Valor Econômico. Disponível em $<\underline{\text { http://www.valor.com.br/politica/1086370/dilma-escolhe-rosa-weber-do-tst-para-o-supremo }}>$. Acesso em 8.12.2011. Em outra matéria, do jornal O Estado de São Paulo, são colacionadas decisões da Ministra favoráveis à expansão dos direitos sociais dos trabalhadores. GALUCCI, Mariângela. Com nova ministra, direitos sociais ganham força na corte. 0 Estado de São Paulo. Disponível em $<$ http://www.estadao.com.br/noticias/impresso,com-nova-ministra-direitos--sociais-ganham-forca-na-corte-$, 796879,0 . \mathrm{htm} ? \mathrm{p}=1>$. Acesso em 8.12.11.
} 
coincidir - pelo menos em parte - com as visões ideológicas da Presidente, caso contrário, teria escolhido outro nome.

Outro elemento importantíssimo para a escolha ao lado da ideologia é a vinculação partidária do indicado.

Nos Estados Unidos, essa associação é muito intensa, em razão da bipolarização partidária entre Democratas e Republicanos e a forte cultura adversarial, exigindo que o cidadão politizado escolha entre um ou outro partido.

Não há, nesse caso, uma expressão ideológica mais diluída e menos agressiva, como no Brasil, onde há partidos mais radicais e outros de centro, assim como aqueles que não são nem situação, nem oposição, caminhando em um limbo de política de boa vizinhança.

Assim como as ideologias em geral, as filosofias partidárias também não são rígidas, sendo difícil afirmar, com precisão, o que elas significam em termos de políticas públicas. Essa fluidez ideológica, contudo, não impediu que os candidatos da Suprema Corte de inspiração liberal ficassem mais próximos dos Democratas, enquanto os conservadores filiam-se aos Republicanos. Esses dois casamentos fizeram com que noventa por cento dos justices indicados fossem do partido do Presidente e, em determinado momento de sua vida, tivessem realizado trabalhos partidários. ${ }^{176}$

A princípio, isso parece ir contra o pensamento brasileiro de que os juízes não devem estar vinculados a partidos políticos, sendo recomendável que eles mantenham distanciamento dessas associações, visto que elas podem corromper sua imparcialidade e desviar suas convicções morais. Todavia, a ideia de um Tribunal neutro e apartidário dentre nós difundida não impediu que vários ex-mandatários assumissem o cargo, como por exemplo, os Ministros Célio de Oliveira Borja, Paulo Brossard de Souza Pinto e Nelsom Jobim, que haviam exercido mandato eletivo. Evidentemente, durante a sua vida pública, estiveram vinculados a um partido político, e nem por isso deixaram de ingressar na Corte.

Nos Estados Unidos da América, também é comum a nomeação de exmandatários de cargo eletivo, como é o caso de Earl Warren (ex-governador) e o já citado Taft, ex-presidente.

Sendo assim, as ideologias de um candidato ao órgão judiciário supremo de um país, andam lado a lado com sua vinculação partidária, embora isso possa ser mais ou

\footnotetext{
${ }^{176}$ BAUM, Lawrence. op. cit. p. 40 e 56.
} 
menos aparente em cada um deles. No Brasil, esse casamento não é tão incisivo como nos Estados Unidos, embora não se possa negar que nos diálogos do poder prevalecem os nomes daqueles que estão mais próximos do Presidente e dos membros de seu partido, o que não significa sua filiação ou trabalho partidário.

Esses dois elementos, ideologia e partidarismo, são fundamentais para a escolha de um membro da Corte, não porque ela deve ser um terceiro locus partidário ao lado do Executivo e Legislativo, mas porque é importante saber as suas convicções e como ele irá se portar na Corte, onde está em jogo a aprovação constitucional das políticas públicas mais sensíveis de um país.

\subsubsection{A symbolic representation}

Ao lado da ideologia e do partidarismo, encontramos outro modelo de escolha que lhes é subsidiário, consubstanciando-se na adoção, explícita ou implícita, de critérios que privilegiam a origem do nomeado, seja em referência a sua condição étnica, econômica, sexual, religiosa ou social.

Esse é um modelo que parece cada vez mais estar presente no Brasil e nos Estados Unidos, acompanhando o papel da Corte na defesa dos direitos humanos e das minorias, o que exige uma representação plural de seus membros que espelhe a própria sociedade que a Constituição preserva.

Nos EUA, foram inúmeras as ocasiões em que a symbolic representation realizou papel importante ou até determinante na escolha. Ronald Reagan teria escolhido meticulosamente Sandra Day O'Connor para o cargo de justice, em razão da expansão dos movimentos feministas e a conquista de maior espaço das mulheres na política nacional.

Igualmente, no Brasil, foi aplaudida a nomeação de Ellen Gracie pelo Presidente Fernando Henrique Cardoso, em 2000, como a primeira mulher da história a ocupar uma cadeira no Supremo Tribunal Federal. Continuando essa trajetória de symbolic representation, poucos anos depois, Luis Inácio Lula da Silva nomeou o primeiro afrodescendente da Corte, Joaquim Barbosa.

Também não é coincidência que a primeira nomeação de Barack Obama tenha sido Sonia M. Sotomayor, a primeira mulher hispânica a ocupar uma vaga da Suprema Corte. 
A representação simbólica, todavia, não é só uma história de vanguardismo, visto que, uma vez conquistada uma cadeira por determinado setor social, há uma defesa quase que intransigente por sua manutenção. É o caso da forte pressão social exercida em Bush para que ele indicasse outro afrodescendente em substituição a Thurgood Marshall, tendo sido nomeado Clarence Thomas.

A própria Presidente Dilma Rousseff parece ter sido aconselhada a indicar outra mulher para preencher a cadeira vaga por Ellen Gracie, em decorrência de sua aposentadoria voluntária em 2011.

A symbolic representation, apesar de constituir um modelo cada vez mais presente nas nomeações, não é o elemento determinante da escolha, mas sim, associado aos dois principais, que é a ideologia e o partidarismo.

Além do mais, a história tem demonstrado que não há uma correlação precisa entre a origem do nomeado e a defesa dos interesses de sua camada social, como seria de se supor. Pretensamente, um juiz que tivesse origem em um setor sub-representado, teoricamente, devotaria uma ação mais incisiva em prol deste, o que não tem sido verificado na prática.

A história nos mostra que várias decisões vanguardistas da Corte em prol de minorias, não necessariamente estão vinculadas ao voto de juízes que fazem parte dessa minoria. Exemplo disso é a decisão Brown, em que todos os juízes presentes na Corte que votaram pelo fim do segregacionismo racial não eram de origem afrodescentente. $\mathrm{O}$ tema do aborto decidido em Roe, embora favorável aos movimentos feministas, contou com uma corte masculina.

No que tange ao ativismo, não se pode negar que a existência de juízes provenientes de grupos sociais diversos oxigena a Corte e abre espaço para a construção de novas leituras constitucionais, embora não seja determinante para sua ocorrência. Acima de tudo, a symbolic representation busca a legitimação da Corte perante a sociedade.

\subsubsection{O processo de seleção e a sua legitimidade democrática}

Muito se argumenta que o ativismo é um fenômeno antidemocrático, na medida em que os juízes superpõem suas convicções pessoais sobre a vontade majoritária expressa nos Poderes Legislativo e Executivo. 
No início deste subcapítulo, nós apresentamos a seguinte indagação: se uma decisão ativista é algo indesejável, que corrói as instituições democráticas e viola a separação de poderes, naturalmente a escolha dos juízes de uma Corte deve recair sobre aqueles que não têm um perfil ativista.

Partindo dessa premissa, verificamos como funciona o processo de seleção desses juízes tanto em âmbito normativo quanto empiricamente, e pudemos perceber que inúmeros atores participam deste processo.

O Poder Executivo tem uma forte assessoria que examina minuciosamente os candidatos, além de sua cúpula partidária e líderes do governo trazerem informações preciosas e intermediarem o diálogo com o Senado.

As associações classistas também expressam sua opinião ou recomendam determinado candidato. Em especial, a elogiável manifestação da ABA, por meio de conceituados estudos e relatórios sobre cada candidato, avaliando sua competência profissional, temperamento judicial e integridade para o cargo.

Os grupos de interesses têm movimentação constante tanto no governo quanto no Parlamento, aproximando-os das aspirações de diversos setores da sociedade que querem ver concretizadas as políticas públicas que lhes são favoráveis, cuja aprovação de constitucionalidade da Corte é fundamental.

Por último, o Senado é um órgão representativo muito bem estruturado e com competências constitucionais das mais elevadas, cujos membros atuam por meio de mandatos outorgados democraticamente, em votações livres, diretas e universais, tanto no Brasil quanto nos Estados Unidos.

Desse modo, não há razão para acreditar que a escolha dos juízes de uma Corte Constitucional seja feita acriteriosamente e desprovida de filtros que possam afastar a indicação daqueles que são considerados nocivos para a democracia, no caso, os de ideologia ativista.

Poder Executivo, associações classistas, grupos de pressão e Senado Federal representam suficientemente os interesses da sociedade, alguns de forma setorizada, outros nacionalmente ${ }^{177}$, conferindo legitimidade democrática ao processo de seleção dos membros da Corte.

\footnotetext{
177 Ainda que o Senado, em tese, represente os Estados, é certo que os senadores representam toda a população de todo os Estados, o que confere legitimidade em âmbito nacional. Além do mais, sendo certo que o número de Senadores é menor do que o da House of Representatives (análoga a Câmara de Deputados), as eleições para o cargo sempre contam com menor número de candidatos, o que faz com que um senador tenha muito mais votos e represente, diretamente, mais cidadãos do que um deputado.
} 
Importa ressaltar que a legitimidade democrática a que se aduz não é aquela vinculada a uma idealista vontade majoritária ou como representação eleitoral (já que os juízes não são eleitos), mas como a expressão da vontade dos poderes democráticos eleitos e da sociedade.

Nesse sentido, as escolhas dos juízes que integrarão a Corte são plenamente conscientes e refletem as aspirações dos órgãos democráticos em termos de suas leituras constitucionais. Não é plausível crer que o Presidente da República e os Senadores não têm conhecimento sobre as ideologias e convicções do futuro membro da Corte, assim como elas conformarão suas decisões no exercício da jurisdição constitucional.

Kermit Roosevel III afirma que os membros da Suprema Corte possuem legitimidade democrática, pois "The process of nomination and confirmation gives the American people through their elected representatives, the chance to say what they want in terms of constitutional interpretation." 178

Essa assertiva, entretanto, merece uma ponderação. Ao que as evidências indicam, essa constatação parece condizer menos com a realidade brasileira e mais com a estadunidense, onde a rica história secular da Suprema Corte amadureceu os poderes políticos e a sociedade para a importância do processo de seleção dos justices.

Essa história tem um marco significativo a partir de 1913, com a promulgação da Emenda 17, que alterou o sistema de eleição dos Senadores, extinguindo a votação indireta realizada pelas Assembléias dos Estados e passando para uma eleição direta pelo povo.

Isso fomentou a expressão popular e classista na escolha dos justices, uma vez que agora os cidadãos e os grupos de interesse tinham um canal de expressão direta nessa seleção por meio de seus representantes.

Aliado a este fato, os anos vindouros foram marcados pelo notório embate entre o Presidente Roosevelt e a Suprema Corte acerca das políticas econômicas nacionais, cuja contenção imediata foi seguida de polêmicas decisões da Corte de Warren e Burguer nas décadas seguintes.

178 "O processo de nomeação e confirmação confere ao povo americano por meio de seus representantes eleitos, a oportunidade de dizer o que eles querem em termos de interpretação constitucional". ROOSEVEL III, Kermit. op. cit. p. 1. 
Esses fatos históricos deixaram claro para toda a nação, com maior afinco ${ }^{179}$, que a Suprema Corte participava sim do decision making process nos EUA e que a seleção de seus membros deveria passar por um crivo democrático. O que efetivamente ocorreu.

Nas palavras de UNAH, "the selection of Supreme Court Justices has become a wholly democratic process." 180

No Brasil, não acreditamos que a escolha de um Ministro do Supremo Tribunal Federal sofra o mesmo escrutínio de legitimidade democrática que existe nos EUA, pois não há uma maturidade dos órgãos políticos e da população acerca da importância do STF na agenda política do país. Isso vem crescendo exponencialmente nos últimos anos, em virtude de inúmeras decisões em sede de reforma eleitoral, proteção a minorias e concretização de direitos sociais.

Em tese, estas decisões deverão fomentar um debate público sobre o papel do Supremo Tribunal Federal nos rumos da nação, impulsionando uma atitude mais proativa do cidadão, da mídia, dos grupos de pressão e dos próprios órgãos políticos constituídos, já que as decisões desse Tribunal influenciam diretamente a vida de cada um deles.

Os julgamentos sobre a verticalização e a fidelidade partidária interferiram diretamente no âmago dos partidos políticos e de suas alianças. A constitucionalização da união homoafetiva, atingiu em cheio a vida de milhares ou milhões de pessoas que nunca tiveram seu direito reconhecido nos Parlamentos e clamavam por justiça e igualdade, enquanto, por outro lado, ela agrediu os princípios morais de grande parcela da população. A concessão judicial de remédios, sem dúvidas, promove a recuperação e melhora a saúde de inúmeros cidadãos, mas também interfere no orçamento do Executivo e pode prejudicar outros enfermos cujos recursos foram desviados.

Isso tudo poderá fomentar um debate público mais rico no Brasil sobre o processo de seleção dos Ministros do STF, que ainda parece estar adstrito a um reinado do Presidente sobre os demais atores apontados. Esse amadurecimento, porém, só será possível se o Senado abandonar a sua postura tímida e exercer seu papel de avaliador crítico dos candidatos, deixando de tratar a sabatina como uma mera estampa da decisão presidencial.

\footnotetext{
${ }^{179}$ A Suprema Corte, mesmo antes de 1917, já participava ativamente do decision making process nos EUA, mas não acreditamos que havia o mesmo apelo popular, como passou a ter no século XX, em razão dos fatos narrados.

180 "a seleção dos juízes da Suprema Corte se transformou em um pleno processo democrático" (tradução nossa). UNAH, Isaac. op. cit. p. 75-78
} 
Não nos parece que a Constituição Federal de 1988, que incorporou a longa história de aprovação senatorial provinda da própria Constituição dos EUA, tenha enxergado essa função formalista do Senado, em especial, em razão da previsão de um quorum absoluto para sua aprovação e a credibilidade institucional desse órgão, cujos membros têm mandatos mais longos e são historicamente mais elitizados.

A população, as organizações classistas e os grupos de interesse também devem se posicionar de maneira mais atuante, principalmente fomentando os Senadores a participarem desse processo ao lado do Executivo, cuja figura única do Presidente é de muito difícil acesso em um país de dimensões continentais e de competências vastas a uma só pessoa.

É função institucional do Senado a aprovação da indicação presidencial, e dada a importância do cargo que está em jogo, ela deve ser feita com seriedade, responsabilidade e combatividade, se preciso for, amadurecendo e selecionando com rigor aqueles que pretendem ocupar um dos cargos mais elevados de uma Nação.

2.4 Hipóteses de vacância: morte, aposentadoria, strategic retirement e impeachment

Após o estudo de como são preenchidos os cargos dos órgãos judiciários supremos, cumpre-nos, brevemente, verificar os fatores que levam à sua vacância, sendo três as causas principais: morte, aposentadoria e impeachment.

Curiosamente, a causa primeira de vacância do cargo em toda a história da Suprema Corte estadunidense é a morte. Quarenta e nove justices faleceram ocupando a nobre função desde $1789 .{ }^{181}$

Esse dado é significativo e tem duas razões capitais. Primeiro, a ausência de aposentadoria compulsória a partir de determinada idade, o que permite que os juízes trabalhem na Corte mesmo com sérias debilidades físicas e até mentais. Segundo, a inexistência de qualquer forma de pagamento de aposentadoria até meados do século XX, não sendo raros aqueles que permaneciam por questões de sobrevivência financeira.

Com o implemento do sistema de aposentadoria voluntária remunerada da Suprema Corte, o número de mortes durante o exercício do cargo caiu vertiginosamente,

${ }^{181}$ UNAH, Isaac. op. cit. p. 32. 
sendo que após o falecimento de Robert H. Jackson em 1954, apenas Willian Rehnquist, em 2005, teve o mesmo infortúnio.

No Brasil, não temos estatísticas sobre o número exato de falecimento de Ministros durante o exercício do cargo no STF, embora acreditemos que não seja a causa primeira de vacância, tendo em vista a existência histórica, dentre nós, da aposentadoria compulsória.

A Constituição Republicana de 1891 não trazia qualquer limite etário para o exercício do cargo de Ministros, razão pela qual os membros que atuaram com idade mais avançada são daquele período, a saber: André Cavalcante, com noventa e três anos de idade e Herminio F. do Espírito Santo com oitenta e três anos. ${ }^{182}$

Foi somente com a Constituição de 1934 que a compulsória foi instituída aos setenta e cinco anos de idade, tendo esse número variado na Carta seguinte e se estabilizado, em 1946, em setenta anos, limite que permanece até os dias atuais.

Questão de interesse que se coloca na doutrina estadunidense é a do strategic retirement, situação em que, alegadamente, os justices da Suprema Corte procurariam se aposentar apenas durante o mandato de um Presidente do mesmo partido daquele que o nomeou.

Tendo em vista o forte embate político, nos EUA, entre Republicanos e Democratas, transportado para a Corte sob o viés ideológico de conservadores e liberais, não é raro que um justice apenas se aposente durante o mandato de um Presidente de seu partido.

Isaac Unah relata o grande espanto que causou o pedido de aposentadoria de Thurgood Marshall (liberal) durante a administração Bush (Partido Republicano) ${ }^{183}$, aduzindo que há uma inclinação dos justices para a strategic retirement, mas que isso não consubstancia uma regra. Diversos elementos contam para a sua ocorrência e, muitas vezes, um justice não pode esperar longas administrações para requerer sua aposentadoria (oito anos se considerada a reeleição), além de poder haver motivos pessoais sérios (como a doença) ou a simples não adesão do justice a esta forma de deixar a Corte.

No Brasil, não se verifica esse fenômeno, tendo em vista, principalmente, a ausência de um sistema político bipartidário e de uma cultura jurídica com traços ideológicos fortes e bem definidos. Não causou espanto o recente pedido de aposentadoria voluntária da Ministra Ellen Gracie, em 2011, durante o governo de Dilma Rousseff (PT),

\footnotetext{
${ }^{182}$ MELLO FILHO, José Celso de. op. cit. p. 18.

${ }^{183}$ UNAH, Isaac. p. 27.
} 
em razão de sua nomeação ter sido feita pelo ex-Presidente Fernando Henrique Cardoso (PSDB).

Por fim, temos o instituto do impeachment, previsto tanto no Brasil quanto nos EUA. Dentre nós, é competência do Senado Federal julgar os Ministros do Supremo Tribunal Federal nos crimes de responsabilidade, nos termos do art. 52, II, CF. Desde a promulgação da Carta de 1988, não houve impeachment de nenhum Ministro, sendo que não encontramos registro de sua ocorrência na história da Corte, ressalvadas notícias de casos de regimes ditatoriais ou militares que removeram os juízes sem um processo legítimo e democrático.

Nos EUA, o impeachment é decorrência da violação do requisito de good behavior previsto constitucionalmente, e nunca se consumou plenamente contra nenhum justice. De acordo com a legislação local, o processo inicia-se na House of Representatives, onde deverá ser votado, e, se aprovado, será remetido para apreciação e votação do Senado.

Apenas o justice Samuel Chase, no início do século XIX, teve votação favorável ao impeachment na House of Representatives, mas posteriormente foi absolvido no Senado. O episódio marcou profundamente a história judiciária dos EUA, devido a suas fortes implicações políticas.

As circunstâncias ao redor do caso eram muito polêmicas, pois envolviam a condução do processo pelo Vice-Presidente Aaron Bur (acusado de homicídio contra Alexander Hamilton em um duelo) e as insatisfações de vários políticos liderados por Thomas Jeferson contra a presidência da Corte por John Marshall, próximo da lista de impeachment. $^{184}$

A absolvição de Chase no Senado não foi apenas uma vitória pessoal. Acima de tudo, significou o reconhecimento de que o Judiciário não deve estar tão próximo do jogo político, fortalecendo a cultura de independência do Judiciário. A intensa disputa entre os Republicanos e Federalistas, em especial, entre Jefferson e Marshal (ironicamente primos), deveria ficar fora das Cortes.

Outro justice que esteve muito próximo do impeachment foi Abe Fortas, em 1969, em razão de um alegado conflito de interesses entre ele e uma fundação para a qual era consultor e tinha um de seus diretores $s u b$ judice ${ }^{185}$. Haja vista a forte inclinação política que lhe era desfavorável durante a administração Nixon, Fortas resignou e o processo não foi adiante.

\footnotetext{
${ }^{184}$ UNAH, Isaac. op. cit. p. 6.

${ }^{185}$ BAUM, Lawrence. op. cit. p. 63.
} 
As hipóteses de vacância da Corte, portanto, não causam grande repercussão no seu ativismo, embora possam ter traços de partidarismo no momento de se deixar a Corte (strategic retirement) ou sofrer impeachment.

2.5 Agenda setting: o que julgar e quando julgar

O presente subcapítulo tem o intuito de examinar como é formada a pauta dos órgãos judiciários supremos no Brasil e nos Estados Unidos, uma vez que o ativismo pode se revelar não só nas decisões efetivamente realizadas, mas também nas não realizadas, já que as Cortes podem afastar ou atrasar o julgamento de determinadas demandas de acordo com os interesses ideológicos de seus membros.

Desse modo, é preciso saber $o$ que as Cortes julgam e quando irão fazê-lo em relação a cada processo, não sob uma leitura normativa (competências e leis processuais), mas sob o enfoque das estratégias que podem ser utilizadas para conformar o resultado do julgamento em prol de determinada posição jurídica. É certo que algumas teses podem ter aceitação majoritária hoje, mas não amanhã.

Esse é um tema muito trabalhado nos Estados Unidos, mas pouco ou nunca estudado no Brasil, e acreditamos que ele merece maior atenção por nós. Dados os limites de nossa dissertação, pinçaremos apenas dois pontos que consideramos fundamentais ( $o$ que julgar e quando fazê-lo) e lhes daremos um tratamento introdutório, esperando que a questão suscite proveitosos debates e se desenvolva na comunidade acadêmica com vigor.

O primeiro tópico da agenda setting se refere à faculdade das Cortes de conhecerem ou não determinados temas dentro de sua esfera de competência, esta última já analisada em subcapítulo próprio.

Primeiramente, deve ficar assentado que, tanto no Brasil quanto nos Estados Unidos, os órgãos judiciários supremos somente atuam por provocação, o que quer dizer que eles não têm a prerrogativa de conhecer determinada matéria por livre e espontânea vontade, a não ser que ela seja suscitada em alguma demanda por terceiros.

Isso é de extrema importância, na medida em que o atuar político das Cortes é, no fundo, uma resposta às pretensões políticas que lhes são levadas a conhecimento por demandantes. Os juízes, a rigor, não decidirão politicamente se não forem provocados 
para tanto, o que quer dizer que, quando as Cortes são rotuladas de ativistas, elas não estão sozinhas, pois há operadores do direito ou setores sociais juntos nessa condição.

Em geral, são os advogados, políticos, promotores ou entidades de classe que levam ao Judiciário os temas considerados ativistas e, fatalmente, qualquer tipo de decisão nessas causas será criticada negativamente. Tomemos a questão da união homoafetiva, por exemplo. Qualquer decisão do Supremo Tribunal Federal será considerada política, pois, se ele negar o pedido, será tachado de conservador e retrógrado, enquanto, se o conceder, será tido como ativista.

Por isso, antes de se rotular as decisões, é preciso avaliar se o Tribunal foi obrigado ou não a conhecer aquele processo, já que a natureza política da causa certamente repercutirá na natureza da decisão, ainda que diversos possam ser os tratamentos acerca de seu mérito.

Desse modo, mister se faz ressaltar que, no Brasil, a competência originária e recursal do Supremo Tribunal Federal é, em sua maioria, compulsória, ou seja, os Ministros devem obrigatoriamente julgar grande parte das ações que ali são interpostas, como a ADI, a ADC, a ADPF, a IF, as denúncias criminais, o MS e o MI. Nesses casos, o STF só poderá negar sua admissibilidade se eles não reunirem algumas das condições processuais; quanto ao mérito, entretanto, não podem ser evitados.

Considerando a linguagem aberta e manipulável das hipóteses de cabimento dessas ações, em especial ADI e ADPF, praticamente todos os temas políticos mais árduos podem ser questionados judicialmente, tanto os que já tiveram alguma normatização (ex: cotas raciais, leis eleitorais e parcelamento de precatórios), como os que ainda não a tiveram (ex: aborto anencefálico, direitos dos homossexuais e fidelidade partidária).

O único instrumento de natureza discricionária do Supremo Tribunal Federal é a Repercussão Geral, recentemente instituída pela EC 45-04, em que os Ministros podem rejeitar o conhecimento de um processo via Recurso Extraordinário pelo voto de 2/3 (dois terços) de seus membros ${ }^{186}$, desde que ele não apresente relevantes questões sob o ponto de vista econômico, social, jurídico ou político e que eles não se restrinjam à lide. ${ }^{187}$

A Repercussão Geral é um importante avanço para a diminuição da avalanche de processos que ingressam na Corte (mais de oitenta mil por ano nos últimos dez anos, com

\footnotetext{
${ }^{186}$ Art. $102, \S 3^{\circ}$, CF. No recurso extraordinário o recorrente deverá demonstrar a repercussão geral das questões constitucionais discutidas no caso, nos termos da lei, a fim de que o Tribunal examine a admissão do recurso, somente podendo recusá-lo pela manifestação de dois terços de seus membros.

${ }^{187}$ Art. 543-A, $\S 1^{\circ}, \mathrm{CPC}$.Para efeito da repercussão geral, será considerada a existência, ou não, de questões relevantes do ponto de vista econômico, político, social ou jurídico, que ultrapassem os interesses subjetivos da causa
} 
o ápice de aproximadamente cento e sessenta mil em $2002^{188}$ ), e tem o condão de afastar o conhecimento das questões mais simples que podem ser adequadamente julgadas por juízes de primeira e segunda instância.

É humanamente impossível que os onze membros do STF, aliados por cinco assessores e um chefe de gabinete cada um, julguem as dezenas de milhares de processos que são ajuizados todos os anos, em um prazo razoável e com a merecida atenção.

A Repercussão Geral, que deveria solucionar esse problema (ao menos em grande parte), tem se mostrado como um passo tímido nessa direção. Primeiramente, porque o quorum estabelecido em lei favorece o conhecimento da ação, quando deveria ser o oposto. Na prática, a Repercussão Geral pode ser conhecida por uma Turma composta por cinco Ministros, não sendo sequer necessário levar o caso ao Plenário. Em segundo lugar, não parece que os Ministros estejam dispostos a limitar consideravelmente a sua esfera de atuação, uma vez que até o momento quase setenta por cento dos casos tiveram a Repercussão Geral reconhecida. ${ }^{189}$

Esses números não advogam a favor de um papel mais contido do Supremo Tribunal Federal e de uma diminuição significativa do número de processos que ali tramitam, comprometendo o seu trabalho e mantendo a cultura jurídica de que juízes de primeiro e segundo grau são instâncias de passagem.

Sendo assim, o conhecimento dos processos no Supremo Tribunal Federal, que já é obrigatório na maioria dos casos, ainda tem sido admitido em elevado percentual na única hipótese em que é possível o exercício da discricionariedade, fazendo com que dezenas de milhares de processos entrem na pauta do Supremo todos os anos, comprometendo seu bom funcionamento e expandindo seu poder de decisão em parcela significativa das lides que tramitam no Judiciário brasileiro.

Nos Estados Unidos, a realidade é completamente oposta.

Praticamente não existem mais ações de conhecimento compulsório pela Suprema Corte. Até o início do século XX, quase todas as ações endereçadas a ela deveriam ser julgadas, até que foi editado o Judiciary Act de 1925, também conhecido como Certiorari Act, em que os justices passaram a exercer grande discricionariedade dos casos em sede de competência recursal. Posteriormente, a discricionariedade foi estendida também para as

\footnotetext{
${ }^{188}$ As estatísticas processuais podem ser encontradas no sítio eletrônico do Supremo Tribunal Federal em $<$ http://www.stf.jus.br/portal/cms/verTexto.asp?servico=estatistica\&pagina=movimentoProcessualGrafico $>$. Acesso em 30.11.2011

189 Os dados podem ser encontrados no sítio eletrônico do Supremo Tribunal Federal. $<$ http://www.stf.jus.br/portal/cms/verTexto.asp?servico=jurisprudenciaRepercussaoGeral\&pagina=numeroR epercussao $>$. Acesso em 30.11.2011
} 
lides de competência originária da Corte por meio da polêmica decisão Ohio v. Wyandotte Chemicals (1971).

Isso quer dizer que, hoje em dia, praticamente todas as petições dirigidas à Corte sofrem juízo discricionário de admissibilidade.

O instrumento processual mais utilizado para se acessar a Suprema Corte é, sem dúvida nenhuma, o writ of certiorari, cuja admissão é determinada pelo voto favorável de quatro justices (rule of four), sem que haja necessidade de fundamentá-los. Embora esse procedimento peque pela falta de transparência, a verdade é que a Corte não quer formar jurisprudência sobre os casos que devem ou não ser admitidos, já que as condições econômicas, políticas e sociais de um determinado momento histórico são fundamentais para o exercício de sua jurisdição sobre os temas mais sensíveis, fazendo com o que o conhecimento de uma lide se dê por razões conjunturais.

Quanto ao quorum de admissão do writ of certiorari, inobstante a rule of four exigir a manifestação positiva de menos da metade dos membros da Corte, o fato é que os justices têm uma forte inclinação a limitar os processos em tramitação na Corte, o que reflete em seus números. Todos os anos são ajuizadas entre 8 e 9 mil petições, sendo que apenas 1 a $2 \%$ delas são admitidas, o que representa o julgamento de pouco mais de 80 casos por ano.

Esses números são significativos por várias razões: i) a Corte exerce grande contenção de sua atuação, podendo se afastar dos temas de matiz político com maior frequência; ii) ao não admitir um caso, ela mantém a decisão de segunda instância, valorizando-a e descentralizando o poder da palavra final na prestação jurisdicional; iii) ao julgar pouco, a Corte pode julgar melhor, mais rápido, e diminuir eventuais incoerências entre os julgados sob uma perspectiva histórica; iv) ao admitir um percentual baixíssimo de ações, há uma diminuição natural no número de petições a ela dirigida, já que é caro e frustrante não ter a ação conhecida.

Existem inúmeras razões para a Suprema Corte ter atingido este quadro atual, destacando-se o processo histórico de seu posicionamento mais limitado na seara das políticas públicas e admitindo uma maior pluralidade decisional dentro do Judiciário.

Certo é que, se os atuais justices quisessem decidir temas polêmicos, teriam instrumentos processuais para tanto, mas não o fazem. Certo é, também, que a comunidade política e os próprios membros das instâncias inferiores do Judiciário os pressionam constantemente para uma atuação mais contida, exigindo respeito das decisões dos demais órgãos. 
Isso faz com que a Suprema Corte estadunidense, embora famosa por seus casos de ativismo judicial, seja, atualmente, um órgão extremamente contido.

Desse modo, encerramos a primeira parte do exame da agenda setting, concluindo que o Supremo Tribunal Federal brasileiro tem determinadas competências que obrigatoriamente o colocam em contato com temas ativistas, devendo haver uma reflexão mais profunda da comunidade acadêmica sobre a jurisdição compulsória em determinadas lides. Todavia, nos casos em que o STF tem condições de limitar sua atuação, não o faz, admitindo uma carga inexecutável de trabalho que prejudica a qualidade dos julgamentos e atrasa-os expressivamente. Esse quadro é o aposto do verificado na Suprema Corte, que exerce discricionariedade em praticamente todos os casos (seja por imperativos legais ou construção jurisprudencial), restringindo sua atuação e favorecendo a pluralidade de decision makers tanto na esfera político-legislativa, quanto na interpretativa-judicial.

O segundo tema que pretendemos examinar na agenda setting é quando o órgão judiciário supremo de um país coloca um caso para julgamento e o decide definitivamente.

A princípio, isso pode parecer irrelevante, mas não o é. São vários os fatores que influenciam o momento em que os juízes resolvem julgar uma causa, principalmente quando se está diante de um tema sensível e de repercussão nacional. Determinadas teses possuem maior força de acordo com as condições políticas, econômicas e sociais conjunturais, além de ser determinante a composição ideológica da Corte.

Nos Estados Unidos, os justices não têm muita liberdade de formação da agenda, pois, de acordo com as práticas da Suprema Corte, todo processo que for admitido em um determinado termo ${ }^{190}$ deverá ser julgado até o seu final. Excepcionalmente, se a Corte não lograr julgá-lo a tempo, carrega-o para o termo seguinte. Na prática, isso quer dizer que um caso será julgado sempre em um ano ou, no máximo, dois.

É importante constatar que não há como os justices postergarem o julgamento de determinada causa para além desse período. Uma vez admitida, será decidida brevemente. Se, por qualquer razão, a Corte acreditar que o tema não deve ser julgado por ela, então a única forma é rejeitar sua admissão desde o início.

No Brasil, a agenda setting funciona de modo diverso, posto que o Supremo Tribunal Federal é compelido a julgar inúmeros temas sensíveis via competência originária, além de admitir a grande maioria dos casos de conhecimento não obrigatório, sem que haja qualquer prazo para o início ou fim de seus julgamentos.

\footnotetext{
${ }^{190}$ O ano de trabalho da Suprema Corte inicia-se na primeira segunda-feira de outubro e termina no recesso de verão, geralmente no final de junho, começo de julho (não há recesso no final de ano).
} 
Uma vez que o processo é devidamente instruído e concluso, o Relator é livre para colocá-lo em pauta quando o voto estiver pronto, o que pode levar alguns dias ou alguns anos. Uma vez em sessão e proferido o voto inicial, qualquer Ministro é também livre para requerer vistas dos autos e analisá-lo pelo tempo que achar necessário.

Todavia, pelas práticas da Corte, o prazo para devolução dos autos é considerado como impróprios, ou seja, os Ministros tem plena liberdade para analisá-los pelo tempo que acharem conveniente, sem qualquer limitação temporal. Isso quer dizer que não há prazo algum para o início ou final do julgamento, sendo uma incógnita quando o processo será julgado e por quem, já que não é raro um Ministro pedir vista, não apresentar voto, e deixar a Corte.

Essa forma de processamento, em que há total liberdade de se julgar o que quiser e quando quiser, não é das mais saudáveis, pois, além de não ser justa nem eficiente, ainda permite o surgimento de inúmeras estratégias processuais, tais como: i) as decisões polêmicas são mais bem aceitas quando o ambiente externo lhes é favorável, podendo o julgador aguardar essas condições; ii) se a composição do Supremo for desfavorável ao posicionamento de determinado Ministro, ele pode pedir vistas e aguardar a mudança dos julgadores; iii) uma ação indesejada, em que o julgador acredita que qualquer tipo de decisão não trará bons frutos, pode ficar simplesmente sem julgamento, "engavetada"; iv) há casos em que o decorrer dos anos altera substancialmente o teor do objeto da lide, o que pode favorecer o posicionamento de um Ministro; v) a existência de uma ação no Supremo Tribunal Federal pode mobilizar a sociedade e o Poder Legislativo, por vezes sendo interessante aguardar qual será a reação popular sobre o tema e se haverá a edição de lei sobre ele.

É difícil afirmar, categoricamente, quando essas manobras são deliberadamente utilizadas, mas o fato é que a forma de processamento do Supremo Tribunal Federal permite sua ocorrência. Não podemos esquecer que os Ministros, como qualquer ser humano, busca sempre concretizar suas opiniões, sendo lícito utilizar os instrumentos que lhe estão à disposição.

Além do mais, não se pode acreditar que a pauta de um órgão judiciário de tamanha envergadura seja feita ao acaso, e que sua morosidade seja fruto, única e exclusivamente, do excesso de trabalho e necessidade de reflexão judicial, o que, em nossa visão, peca pela inconsistência e ingenuidade.

Um dos casos mais emblemáticos que poderíamos citar é o da ADI 4467, em que foi questionada a constitucionalidade do art. 91-A, caput, da Lei 9.504-09, que obrigava o 
porte do título de eleitor e do documento pessoal (RG) por todos os eleitores no momento da votação. Uma lide desse quilate, que geralmente demoraria anos para ser julgada, foi posta em Plenário em apenas cinco dias e praticamente todos os Ministros proferiram votos de imediato.

Ao pedir vista dos autos, o Ministro Gilmar Mendes foi repreendido pelos seus colegas, que lhe recomendaram que trouxesse o processo para julgamento já no dia seguinte, alegando que se tratava de uma matéria eleitoral que exigia o imediato julgamento, de modo que surtisse efeito nas eleições que se aproximavam.

Todavia, esse argumento não convence, pois outros casos, de teor eleitoral tão relevante quanto esse, não foram julgados em tão rápido período, tampouco ações que versavam de temas discutivelmente mais relevantes. Além do mais, se era uma causa tão importante, deveria ter sido julgada em definitivo e não apenas liminarmente. Até hoje, mais de um ano após o julgamento da medida cautelar, subsiste a liminar sem definição do mérito.

Não é consistente afirmar que a importância da causa exige o julgamento da liminar em alguns dias e o objeto principal sofra reflexão de alguns anos.

A atuação do Supremo Tribunal Federal, nesse caso, foi largamente criticada e o próprio Ministro Gilmar Mendes asseverou em seu voto os riscos de uma agenda setting política da Corte:

Chamo a atenção para o viés político desta propositura, e mais ainda, para o risco que esta Corte corre de, sem se aperceber de detalhes do jogo político, ser manuseada na busca deste ou daquele interesse eleitoral.

É claro que é legítimo ao partido político utilizar de forma política ação direta de inconstitucionalidade. O que não se pode permitir é que esta Corte embarque nessa estratégia política. Recorde-se, aqui, o intenso debate que existe no direito comparado sobre a politização da jurisdição constitucional. Na Alemanha, inclusive, há uma expressão corrente no meio político "Wir sehen uns in Karlsruhe", que significa levar para o Tribunal Constitucional - que tem sede na cidade de Karlsruhe - questões políticas decididas sem consenso no parlamento (Bundestag). ${ }^{19}$

Sobre o caráter político da lide, ressaltou o Ministro que:

A despeito de a referida norma estar vigente há um ano, é curioso notar que apenas agora, a poucos dias das eleições do dia 3

${ }^{191}$ ADI 4467. Voto do Ministro Gilmar Mendes. p. 4. 
de outubro de 2010, o Diretório Nacional do Partido dos Trabalhadores pleiteia a sua inconstitucionalidade, inclusive com pedido liminar.

Dessa forma, revela-se o viés eminentemente político da pretensão, que se verifica, neste juízo liminar, inclusive por meio da incoerência entre a argumentação apresentada pelo autor em suas razões e a sua postura desde a discussão do Projeto de Lei 5498/2009 no âmbito do Congresso Nacional.

$[\ldots]$

É necessário deixar claro que estamos a três dias do pleito eleitoral, com todos os atos preparatórios já praticados conforme a regra em vigência, sem que o TSE, os partidos políticos, os candidatos e a sociedade em geral tenham se oposto de forma clara à norma em vigor.

Não posso deixar de demonstrar que tudo não passa de uma oportunidade política, de claro sentido, mas com resultado duvidoso para o pleito que se avizinha. ${ }^{192}$ (grifos do autor)

A agenda setting do Supremo Tribunal Federal, portanto, não é obra do acaso e tem motivos reais para sua formatação, o que exige uma atenção maior da doutrina sobre o tema.

Acreditamos que o modelo de julgamento da Suprema Corte é muito mais eficiente, justo e condizente com o órgão julgador coletivo que ela representa, na medida em que todos os justices estudam o mesmo caso previamente e decidem em uma só sessão, não sendo possíveis os pedidos de vistas reiterados e sem prazo para devolução. Admitida a ação, ela certamente será julgada em um ou dois anos, no máximo.

Concluímos, portanto, que o modelo de processamento atual do Supremo Tribunal Federal não favorece a elaboração de uma pauta transparente e consistente no que tange ao momento de julgamento definitivo da ação, tornando-a ineficiente, injusta e questionável, o que permite um manejo político e ideológico da agenda setting próprio de uma atuação ativista.

2.6 Autoridade individual vs autoridade coletiva

Neste subcapítulo, avaliaremos como a forma de julgamento dos órgãos judiciários pode favorecer ou refrear o ativismo judicial. Se é certo que esse fenômeno é visto, por uma de suas perspectivas, como a imposição da ideologia do juiz em detrimento da lei,

\footnotetext{
${ }^{192}$ ADI 4467. Voto do Ministro Gilmar Mendes p. 2-3.
} 
com maior vigor ela ocorrerá quando o julgador não tiver limites de atuação, estando livre para decidir da forma como quiser.

Por outro lado, se o órgão judicial for pautado por uma atuação coletiva, então as múltiplas opiniões advindas de cada um dos julgadores deverão ser articuladas para alcançar um resultado final majoritário ou unânime, caso em que, provavelmente as posições mais radicais serão afastadas e as ideologias individuais irão refrear umas às outras.

Essa é a mesma razão que está por detrás do próprio sistema representativo democrático, em que se pressupõe que as deliberações coletivas dos representantes do povo geram resultados mais prudentes e satisfatórios do que a decisão individual de um só homem (monarca, imperador, etc.).

Evidentemente, essa expectativa teórica nem sempre corresponde à prática, não sendo impossível que representantes ajam concertadamente a favor de uma ditadura da minoria, tampouco que haja um bom governo de um homem só. Da mesma forma no Judiciário, é possível que Cortes julguem coletivamente de forma ativista, enquanto que um juiz pode ter uma posição isolada de autocontenção.

As especulações teóricas, embora não garantam resultados reais ótimos, são úteis na medida em que fornecem elementos para alcançá-los, conferindo maior probabilidade de sucesso. A questão, portanto, não é examinar as formas de julgamento e asseverar qual delas garante o menor nível de ativismo da Corte, mas qual das alternativas tem maior chance de alcançá-lo.

Nesse sentido, parece-nos claro que um Judiciário que atua coletivamente tem maiores probabilidades de autocontenção, já que a pluralidade ideológica tornará mais difícil o acordo sobre temas mais polêmicos e sensíveis, fazendo com que a Corte não alcance maioria nessas questões. Justamente o contrário ocorre quando há apenas um julgador, situação em que ele se torna senhor absoluto da decisão.

Se compararmos a forma de julgamento do Supremo Tribunal Federal com o da Suprema Corte, veremos que, dentre nós, a autoridade individual do juiz é muito significativa, enquanto a segunda pauta-se pela atuação colegiada de seu órgão.

No Brasil, existem vários mecanismos processuais que permitem que o Ministro do STF julgue monocraticamente um processo, ou seja, tome a decisão sozinho. Essas prerrogativas estão expressas nos artigos 544, 545 e 547, CPC, ${ }^{193}$ em que o Relator do

\footnotetext{
${ }^{193}$ Art. 544, CPC. Não admitido o recurso extraordinário ou o recurso especial, caberá agravo nos próprios autos, no prazo de 10 (dez) dias.(..)
} 
recurso tem amplíssima competência para rejeitá-lo, admiti-lo, provê-lo ou improvê-lo, com base em critérios de elasticidade discutíveis, e.g., a "jurisprudência dominante da Corte.". 194

Não se pode omitir que o Codex Processualis tentou minimizar a possibilidade de erros de julgamento ou interpretações isoladas, permitindo a interposição de Agravo Regimental dessas decisões monocráticas. Embora o intuito fosse nobre, pragmaticamente, seus efeitos são baixos, já que milhares de processos são julgados monocraticamente e, a revisão de todos eles agravaria ainda mais o já saturado processamento do Tribunal, o que leva à constatação de que a grande maioria das decisões monocráticas são mantidas colegiadamente.

Isso sem levar em consideração que o Agravo Regimental se dirige a uma das Turmas do STF e não ao Plenário, o que faz com que o processo, ao invés de ser conhecido por apenas um julgador, seja conhecido por cinco, e não pelos onze que compõem a Corte.

Essa divisão de Turmas, inclusive, não parece ser a mais adequada sob o ponto de vista da autoridade colegiada do STF, uma vez que é possível que uma Turma assente

$\S 4^{\circ}$ No Supremo Tribunal Federal e no Superior Tribunal de Justiça, o julgamento do agravo obedecerá ao disposto no respectivo regimento interno, podendo o relator:

I - não conhecer do agravo manifestamente inadmissível ou que não tenha atacado especificamente os fundamentos da decisão agravada;

II - conhecer do agravo para:

a) negar-lhe provimento, se correta a decisão que não admitiu o recurso;

b) negar seguimento ao recurso manifestamente inadmissível, prejudicado ou em confronto com súmula ou jurisprudência dominante no tribunal;

c) dar provimento ao recurso, se o acórdão recorrido estiver em confronto com súmula ou jurisprudência dominante no tribunal.

Art. 545. Da decisão do relator que não conhecer do agravo, negar-lhe provimento ou decidir, desde logo, o recurso não admitido na origem, caberá agravo, no prazo de 5 (cinco) dias, ao órgão competente, observado o disposto nos $\S \S 1^{\circ}$ e $2^{\circ}$ do art. 557.

Art. 557. O relator negará seguimento a recurso manifestamente inadmissível, improcedente, prejudicado ou em confronto com súmula ou com jurisprudência dominante do respectivo tribunal, do Supremo Tribunal Federal, ou de Tribunal Superior.

$\S 1^{\circ}$-A Se a decisão recorrida estiver em manifesto confronto com súmula ou com jurisprudência dominante do Supremo Tribunal Federal, ou de Tribunal Superior, o relator poderá dar provimento ao recurso.

$\S 1^{\circ}$ Da decisão caberá agravo, no prazo de cinco dias, ao órgão competente para o julgamento do recurso, e, se não houver retratação, o relator apresentará o processo em mesa, proferindo voto; provido o agravo, o recurso terá seguimento.

$\S 2^{\circ}$ Quando manifestamente inadmissível ou infundado o agravo, o tribunal condenará o agravante a pagar ao agravado multa entre um e dez por cento do valor corrigido da causa, ficando a interposição de qualquer outro recurso condicionada ao depósito do respectivo valor.

${ }^{194}$ Difícil asseverar o que é "dominante" na Corte, posto que não há um critério preciso sobre qual o momento temporal de aferição, ou seja, se devem ser consideradas todas as decisões de sua história, somente após a Constituição de 1988, dos últimos anos, ou da composição atual de julgadores. Além do mais, ainda que pudesse ser fixado um momento temporal, em um Tribunal que julga dezenas de milhares de processos todos os anos, não parece crível ser possível pesquisar todos dentro daquele período para asseverar qual é o posicionamento majoritário das decisões proferidas. 
entendimento diverso de outra, fazendo com que a incoerência (um dos aspectos do ativismo) tenha maior possibilidade de florescer.

Em mais de uma oportunidade, o Supremo Tribunal Federal se deparou com contradições internas graves, seja em razão do excesso de autoridade individual, ou pela divisão em Turmas.

Ilustrativamente, citamos o caso da Lei Ficha Limpa, em que alguns demandantes tiveram a candidatura deferida e outros indeferida por meio de liminares ${ }^{195}$, já que os Ministros detinham poder para julgar livremente enquanto a Corte não se manifestasse em definitivo, o que, infelizmente, costuma demorar meses ou anos, causando grave insegurança jurídica e instabilidade político-social.

Outra questão que incomoda (ou deveria incomodar) é a perpetuação sine die de decisões monocráticas ou liminares sobre questões de extrema relevância. A ADPF 186, que trata do sistema de cotas universitárias, teve sua liminar julgada por um único Ministro, que autorizou a sua permanência no caso questionado até posterior decisão em definitivo. Até o momento, mais de dois anos se passaram e ainda não foi julgada sequer a liminar pelo Plenário ${ }^{196}$, o que quer dizer que o sistema de cotas permanece em vigor judicialmente em razão do posicionamento provisório de apenas um Ministro do Supremo Tribunal Federal.

Não se está aqui advogando pelo fim dos votos monocráticos ou das Turmas que, aparentemente, foram estabelecidos em razão da quantidade expressiva de trabalho da Corte (a existência de outras razões não foram por nós estudadas). O que se constata é que, sob o enfoque do ativismo judicial, essas duas características de julgamento do STF (voto monocrático e divisão em Turmas) favorecem-no significativamente, sendo imperiosa a reflexão sobre ela.

Nos Estados Unidos, a Suprema Corte tem uma atuação mais coletiva, sendo quase nenhum o poder individual de decisão de um juiz.

O processamento e julgamento da Suprema Corte funcionam, em linhas gerais, da seguinte maneira. Uma vez interposta uma petição à Corte, ela deve ser admitida pelo ‘plenário' (que sequer é assim chamado, pois não há divisões internas) sob o quorum da

\footnotetext{
${ }^{195}$ Como exemplo, citamos a manutenção, liminar, do indeferimento da candidatura na Ação Cautelar 2792, enquanto que na Ação Cautelar 2763 a liminar foi deferida e permitida a diplomação do candidato.

${ }^{196} \mathrm{O}$ julgamento de liminar na ADPF, ad referendum do Plenário, está prevista no art. $5^{\circ}$ da Lei 9882-99, nos seguintes termos: Art. $5^{\circ} \mathrm{O}$ Supremo Tribunal Federal, por decisão da maioria absoluta de seus membros, poderá deferir pedido de medida liminar na arguição de descumprimento de preceito fundamental. $\S 1^{\circ} \mathrm{Em}$ caso de extrema urgência ou perigo de lesão grave, ou ainda, em período de recesso, poderá o relator conceder a liminar, ad referendum do Tribunal Pleno.
} 
rule of four. Em caso positivo, a parte é intimada a apresentar briefs on the merits (razões recursais) em 45 dias, sendo que a outra parte tem 30 dias para se defender (contrarrazoar). Todos os justices recebem as peças processuais e estudam previamente o caso, sendo que a Corte, então, agenda uma data para os oral arguments (debates orais) em que cada litigante e eventuais terceiros (amicus curiae) terão, a princípio, 30 minutos para expor suas razões, podendo ser questionados por todos os justices, na mesma ocasião. Ao final, sendo certo que todos já tomaram contato com o caso e tiveram chance de debatê-lo, a votação é realizada e tomada a decisão na mesma sessão, em que, inclusive, um dos justices é nomeado para escrever a opinion (voto/acórdão).

Como visto, a forma de processamento e julgamento da Corte é colegiada e há pouca esfera de atuação individual dos justices $^{197}$, o que certamente faz com que algumas interpretações jurídicas isoladas não sejam alimentadas.

O chief justice Renhquist, com muita propriedade, asseverou que "judging inevitably has large individual component in it, but the individual contribution of the good judge is filtered through the deliberative process of the Court as a body". ${ }^{198}$

Certamente, a deliberação coletiva é um dos mais importantes elementos para refrear os impulsos e paixões pessoais.

Dessa forma, podemos concluir que o modelo de processamento e julgamento do Supremo Tribunal Federal brasileiro favorece a autoridade individual do julgador, e, em decorrência, o ativismo é impulsionado pela ausência de freios e limites próprios de um órgão que atua coletivamente, ao passo que a Suprema Corte estadunidense pauta-se pela deliberação conjunta de todos os seus membros, sendo quase nenhum o poder de decisão individual de cada um deles.

2.7 Implementation process: a autoefetividade das decisões, a reversão legislativa e o desrespeito social.

Um tema bem trabalhado nos Estados Unidos e que acreditamos ser de muita importância para o tema do ativismo é a implementation process, ou seja, o processo de

\footnotetext{
${ }^{197}$ Os justices têm poucos poderes decisórios isolados, como, por exemplo, suspender determinados efeitos da decisão de segunda instância enquanto a ação não for julgada em definitivo pela Corte. Para maiores detalhes, ver os artigos 21, 22 e 23 das Rules da Suprema Corte (Regimento Interno).

198 "julgar, inevitavelmente, tem um largo componente individual, mas a contribuição individual do bom juiz é filtrada pelo processo deliberativo da Corte como um corpo" (tradução nossa). UNAH, Isaac. op. cit. p. 129.
} 
concretização das decisões judiciais. Isso porque a relevância do ativismo não está unicamente associada aos termos das decisões judiciais, mas também aos efeitos e modificações no mundo real que elas provocam.

Uma decisão judicial, em grande medida, tem a garantia de seu respeito e efetividade diretamente ligada à autoridade formal e moral do órgão que a emanou. $\mathrm{O}$ Poder Judiciário não detém o orçamento, capacidade administrativa e poder de polícia suficiente para criar, alterar ou anular as políticas públicas de um país, a não ser que os poderes políticos e a sociedade acatem suas decisões e as executem.

É por isso que a doutrina estadunidense considera que a credibilidade e a persuasão são os maiores aliados do Poder Judiciário, uma vez que o Executivo e o Congresso têm força para desgastar e refrear sua atuação por meio de inúmeras medidas, como limitar a competência da Corte e seus instrumentos processuais, impor mandatos curtos para "expulsar" legalmente determinados justices, utilizar os vencimentos deles como moeda de troca, ou até tomar providências mais radicais, como realizar o impeachment dos juízes.

A Suprema Corte, desde os seus primórdios, tem consciência da autoefetividade limitada de seus julgados, o que restou evidenciado na decisão Marbury v. Madison em que o chief justice John Marshall sabia que a expedição de uma ordem de writ of mandamus ao Presidente Jefferson provavelmente seria desprezada e a Corte nada poderia fazer a respeito.

Em outro julgamento polêmico, Worcester v. Georgia, após a prolatação da decisão da Suprema Corte, o então Presidente Andrew Jackson teria dito que "John Marshall has made his decision, now let him enforce $i t^{\text {"199 }}$, claramente demonstrando a indisposição do Executivo em seguir a determinação judicial.

A história estadunidense revela uma certa combatividade dos Poderes Executivo e Legislativo contra a interferência da Suprema Corte nas políticas públicas nacionais, ao contrário do Brasil, especialmente em seu recente período pós-88, em que ainda parece pairar um grande respeito (até certo ponto irrestrito) pela autoridade do Supremo Tribunal Federal.

Foram vários episódios na história da Suprema Corte em que os Poderes entraram em rota de choque, sendo o mais conhecido deles o Court-packing Plan do Presidente Roosevelt. A lei por ele proposta, na década de 30, previa o aumento do número de membros da Suprema Corte, de modo que ele pudesse nomear novos justices que não

\footnotetext{
199 "John Marshal tomou a sua decisão, agora deixo-o concretizá-la" (tradução nossa). UNAH, Isaac. op. cit. p. 165.
} 
estivessem vinculados ideologicamente com as doutrinas da Corte de Warren, que já havia julgado inconstitucionais várias leis econômicas do New Deal, programa do Executivo para fomentar o crescimento econômico da combalida nação pós-crise de 1929.

Estando latente o descontentamento do Executivo e de setores do Congresso com as interpretações ativistas da Suprema Corte, ela decidiu recuar em suas doutrinas e o plano de Roosevelt foi tirado de pauta. Esse episódio ficou conhecido como the switch in time that saved nine.

Outras situações revelaram que a Corte pode ser limitada não só pelas pressões e ameaças dos demais Poderes, mas também pela sua incapacidade de concretizar suas decisões isoladamente.

Isso restou evidente em Brown v. Board of Education, precedent que determinou o fim da segregação racial nas escolas públicas estadunidenses. Certamente não havia condições materiais para que as escolas se adequassem imediatamente, razão pela qual em Brown $I I^{200}$, a Corte determinou que elas promovessem as mudanças necessárias "with all deliberate speed", ou seja, com a velocidade possível. Após 9 (nove) anos do julgado, apenas $2 \%$ das escolas do Sul haviam se adequado ${ }^{201}$, o que quer dizer que $98 \%$ não mostravam muita disposição em cumprir a decisão da Corte.

No fundo, ela pouco podia fazer a respeito, já que não lhe compete executar obras públicas tampouco administrar escolas, além de precisar ser provocada para agir mais incisivamente, o que ocorreu em um caso emblemático de uma escola em Little Rock, Arkansas, em que o Exército foi solicitado para garantir o acesso de alunos negros. Ainda assim, vale lembrar que o Exército tem como chefe superior o Poder Executivo, e a solicitação judicial necessariamente foi por ele avalizada.

Foi só com o auxílio do Executivo e do Legislativo e a promulgação do Civil Rights Act de 1964 que as escolas finalmente passaram a se adequar à Brown, uma vez que a supracitada lei previa o fim das transferências de receitas federais às escolas segregacionistas. Ao fim e ao cabo, as palavras da Corte não foram fortes o suficiente para concretizar o fim da segregação em todo o território nacional, sendo necessária a "ameaça" dos cofres do governo.

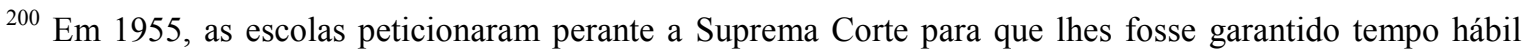
para realizar a reestruturação exigida para dar fim à segregação racial. A decisão final da Corte ficou conhecida como Brown II.

${ }^{201}$ BAUM, Lawrence. op. cit. p. 185.
} 
Essa é uma das razões pelas quais Ackerman assevera que a Suprema Corte não é o único órgão que define e decide as políticas públicas, mas um intermediador histórico da agenda política nacional. ${ }^{202}$

No Brasil, não vemos esse embate manifesto entre os Poderes na mesma intensidade que nos Estados Unidos, embora o Supremo Tribunal Federal já tenha se apercebido de algumas nuances de sua atuação que podem limitar a efetividade de suas decisões.

No caso do Município de Santo André, em que o STF determinou a criação de vagas de creche às crianças em razão da necessidade de concretização do direito constitucional à educação, o Ministro Celso de Mello ponderou que o cumprimento de tal ordem dependia de recursos financeiros e, portanto, estava ciente de que a decisão dependia de fatores externos à mera interpretação constitucional. Desse modo, asseverou ser prudente que o Judiciário verificasse as medidas reais tomadas pelo Poder Executivo Municipal para se atingir tal finalidade, impedindo manobras orçamentárias para frustrar a decisão. Nesse sentido:

Não se ignora que a realização dos direitos econômicos, sociais e culturais - além de caracterizar-se pela gradualidade de seu processo de concretização -, depende, em grande medida, de um inescapável vínculo financeiro subordinado às possibilidades orçamentárias do Estado, de tal modo que, comprovada, objetivamente, a alegação de incapacidade econômico-financeira da pessoa estatal, desta não se poderá razoavelmente exigir, então, considerada a limitação material referida, a imediata efetivação do comando fundado no texto da Carta Política."

Não se mostrará lícito, contudo, ao Poder Público, em tal hipótese, criar obstáculo artificial que revele - a partir de indevida manipulação de sua atividade financeira e/ou político-administrativa - o ilegítimo, arbitrário e censurável propósito de fraudar, de frustrar e de inviabilizar o estabelecimento e a preservação, em favor da pessoa e dos cidadãos, de condições materiais mínimas de existência (ADPF 45/DF, Rel. Min. CELSO DE MELLO, Informativo/STF n 345/2004)., ${ }^{, 203}$

Desse modo, a decisão do Supremo Tribunal Federal sofre limitações sob o ponto de vista orçamentário, administrativo e legal, já que o Executivo municipal depende de outros fatores para cumprir a decisão, devendo observância não só ao STF, mas também à Lei Orçamentária, à Lei de Responsabilidade Fiscal, à Lei de Licitações e ao Tribunal de Contas.

\footnotetext{
${ }^{202}$ ACKERMAN, Bruce. The living constitution. Harvard Law Review, Cambridge, vol. 120, $\mathrm{n}^{\mathrm{o}}$ 7, pp. 1737-1812, maio de 2007.

${ }^{203}$ AgRgRE 410.715. p. 12-13.
} 
A seguir, analisaremos brevemente dois fatores que podem limitar a atuação das Cortes e, consequentemente, do ativismo judicial: a reversão legislativa e o desrespeito pela sociedade das decisões judiciais.

No primeiro caso, o Poder Legislativo edita uma lei contrária ao entendimento jurisprudencial firmado, mitigando ou anulando seus efeitos concretos. Isso ocorreu com pouca frequência na história dos Estados Unidos, mas tem sido cada vez mais visto no Brasil nos últimos anos.

Podemos citar várias decisões do Supremo Tribunal Federal em sede de matéria eleitoral que foram alteradas por diplomas legislativos após manifestação polêmica da Corte, considerada por uns como ativista. Nesse sentido, o caso Mira Estrela (RE 197.917), que afastou a interpretação literal do número de vereadores previsto na Constituição brasileira, mas depois perdeu sua eficácia com a promulgação da EC 58/09 que promoveu nova disposição sobre a matéria.

Questão similar ocorreu quando da exigência de verticalização das coligações partidárias nas eleições de 2002, por interpretação jurídica discutível realizada pelo Tribunal Superior Eleitoral e confirmada pelo Supremo Tribunal Federal. Apesar do respeito da nova regra pelos partidos políticos, houve alteração legislativa logo em seguida por meio da EC 52-06 204 , que afastou expressamente a verticalização.

Sobre o tema, a ilustre professor Monica Herman Salem Caggiano assentou que

Em cenário brasileiro, esta funcão normativa estendida do Poder Judiciário alcancou diferenciado nível, em especial, no espectro eleitoral, onde os analistas puderam, nos últimos anos, testemunhar uma efetiva revolução. Assim, o espectador pode acompanhar a própria Reforma Política - diante da postura de letargia do Poder Legislativo - vir a ser parcialmente cumprida pela interveniência do Judiciário ${ }^{205}$ (grifos do autor)

Esses casos demonstram que o Poder Legislativo brasileiro não está inerte quanto ao ativismo do Poder Judiciário, afastando algumas interpretações constitucionais que advogam contra os seus interesses.

\footnotetext{
${ }^{204}$ A EC 52-06 deu nova redação ao art. 17, §1 da CF, que ficou assim disposto: “§ $1^{\circ}$ É assegurada aos partidos políticos autonomia para definir sua estrutura interna, organização e funcionamento e para adotar os critérios de escolha e o regime de suas coligações eleitorais, sem obrigatoriedade de vinculação entre as candidaturas em âmbito nacional, estadual, distrital ou municipal, devendo seus estatutos estabelecer normas de disciplina e fidelidade partidária."

${ }^{205}$ CAGGIANO, Monica Herman Salem. op. cit. p. 111.
} 
A reversão legislativa verificada no Brasil, entretanto, não ocorre com a mesma intensidade nos Estados Unidos, embora haja inúmeros debates sobre o tema. Em especial, após a decisão Texas v. Johnson, que estabeleceu o direito de se queimar a bandeira estadunidense como manifestação da liberdade de expressão, o Congresso Nacional, por mais de uma vez, tentou aprovar uma Emenda Constitucional proibindo tal ato, o que levantou dúvidas de alguns doutrinadores sobre a constitucionalidade de tal emenda ${ }^{206}$.

O segundo fator de limitação do implementation process que mencionamos é o do respeito social às decisões da Corte. Nesse aspecto, é preciso considerar que os olhos do órgão judiciário não conseguem estar em todos os lugares, sendo indispensável que a própria sociedade efetive e fiscalize suas determinações.

Já mostramos que o caso Brown não foi prontamente aceito e cumprido pelas escolas do Sul, certamente porque seus corpos diretivos não concordavam com o fim da segregação racial, o que foi apoiado, em boa medida, pela comunidade local. O mesmo tem ocorrido mais recentemente com a decisão Engel v. Vitale, em que a Suprema Corte determinou a proibição de se orar em escolas públicas (dado o caráter laico do ensino estatal), mas ela não tem sido observada pela maioria das escolas ${ }^{207}$.

Sobre este tema, Unah assevera que

Realistically, there will always be individuals or groups that stand to lose either directly or indirectly from a Court decision, and so might be motivated to sabotage the Court's policy objectives rather than to see them come to fruition[... $]^{208}$

Dentre nós, embora não haja estudos sobre o tema, podemos lançar dúvidas acerca do real respeito e efetividade do entendimento firmado pelo Supremo Tribunal Federal na Súmula Vinculante n. 11, que permite o uso de algemas apenas em casos excepcionais.

É impossível que o STF fiscalize todas as condutas policiais para verificar se a Súmula está sendo corretamente aplicada, havendo a necessidade de que os próprios policiais a respeitem, ou que os cidadãos provoquem o Judiciário em caso de sua violação. Se houver uma complacência do Poder Público e da sociedade quanto à inobservância da súmula, o Judiciário pouco poderá fazer para concretizá-la.

\footnotetext{
206 O’BRIEN, David M. op. cit. p. 89-91. Não se deve olvidar que nunca na história dos Estados Unidos a Suprema Corte julgou inconstitucional um Amendment.

${ }^{207}$ UNAH, Isaac. op. cit. p. 186-187.

208 "Realisticamente, sempre haverá indivíduos ou grupos que resistirão a perder direta ou indiretamente com uma decisão da Corte, e podem estar motivados a sabotar os objetivos das políticas da Corte ao invés de vêlas se concretizar." (tradução nossa).UNAH, Isaac. op. cit. p. 166.
} 
Concluímos este subcapítulo, demonstrando que as decisões dos órgãos judiciários supremos não gozam de autoefetividade absoluta, sendo que os Poderes Executivo e Legislativo e a sociedade podem limitar a atuação dos Tribunais se assim desejarem, freando seus impulsos ativistas.

2.8 Conclusões preliminares

I - as inúmeras alterações de regimes políticos e mudanças constitucionais desde a Independência brasileira não permitiram um amadurecimento do Supremo Tribunal Federal no seio do Estado nacional e de sua relação com os demais Poderes e a sociedade, ao contrário do ocorrido nos EUA, onde houve uma considerável estabilidade políticoconstitucional nos últimos dois séculos.

II - a competência originária do Supremo Tribunal Federal é amplíssima e coloca-o em contato com delicados temas de matiz político por meio de ações como a ADI, a ADPF e a IF. Por sua vez, a Suprema Corte tem competência originária restritíssima e desenvolveu uma sólida jurisprudência para realizar juízo discricionário das ações ali ajuizadas originariamente.

III - a competência recursal do STF e a da Suprema Corte são significativamente amplas, sendo que, em tese, pode ser revertida praticamente toda decisão judicial proferida pelos Tribunais inferiores de todo o País. Todavia, a Suprema Corte limita drasticamente a sua jurisdição por meio do writ of certiorari, conhecendo, aproximadamente, somente $1 \%$ a $2 \%$ dos recursos ali interpostos, enquanto que o Supremo Tribunal Federal tem reconhecido a Repercussão Geral em quase 70\% dos Recursos Extraordinários.

IV - o controle de constitucionalidade brasileiro confere maior liberdade de atuação dos julgadores do que a judicial review, na medida em que ele pode ser exercido na forma concreta ou abstrata, além de haver autorização legal para prolatação de sentenças aditivas e modulação de efeitos. 
V - a forma de composição do Supremo Tribunal Federal e da Suprema Corte, sob o viés normativo, é bastante similar, embora a práxis estadunidense revele um processo de legitimação de matiz democrático muito mais profundo do que o brasileiro, na medida em que os órgãos políticos (Executivo e Legislativo) participam ativamente da escolha junto aos partidos políticos, entidades classistas, grupos de interesse e opinião pública. Dentre nós, a escolha tem forte conotação personalíssima do Presidente e o Senado atua timidamente.

VI - a agenda setting da Suprema Corte e do Supremo Tribunal Federal e Suprema Corte são radicalmente distintos. Enquanto na primeira todos os casos admitidos são julgados em 1 (um) ou, no máximo, 2 (dois) anos, no segundo não há qualquer previsão ou ordem de julgamento, o que torna a pauta imprevisível e manipulável.

VII - o processamento das ações e a forma de julgamento do Supremo Tribunal Federal confere ampla liberdade de atuação individual de seus Ministros, o que impulsiona as tendências ativistas que não encontram freios e limites próprios dos órgãos de deliberação coletiva, onde as convicções e ideologias pessoais são naturalmente filtradas.

VIII - as decisões judiciais, em grande medida, não tem autoefetividade, sendo necessária a intermediação dos poderes públicos e da sociedade para sua concretização, o que representa um importante freio aos impulsos ativistas de uma Corte. 


\section{CONCLUSÕES}

I - a expressão ativismo judiciário (ou judicial) é comumente empregada com viés negativo e sentido reprovador, em referência a atuações alegadamente indevidas do Poder Judiciário, que ocorrem quando o magistrado: i) julga de acordo com as suas ideologias (ou convicções e valores pessoais) em detrimento do sentido normativo; ii) cria o direito ao invés de apenas interpretá-lo e aplicá-lo; iii) age politicamente, formulando e concretizando políticas públicas, cuja competência é dos demais Poderes; iv) julgar em desconformidade com o posicionamento firmado na própria jurisprudência da Corte. Todas essas concepções, correlatas entre si, combatem aquilo que seus críticos consideram como uma expansão ilegítima do Poder Judiciário que viola a separação de poderes e corrói a democracia.

II - considerando que os conceitos devem refletir o conteúdo do objeto (ou fenômeno) analisado, por meio da atribuição de propriedades ou características que permitem a sua delimitação e identificação, os conceitos expostos de ativismo judicial apresentam inconsistências de difícil superação, pois utilizam termos ambíguos para descrever seu conteúdo, de modo que a delimitação e identificação restam inviáveis. Em termos práticos, os conceitos expostos não permitem identificar de forma consistente, sistemática e sem artificialismos, em quais situações a atuação do Tribunal ou decisão judicial é ou não ativista, pois seus atributos são por demais vagos.

III - a ausência de parâmetros precisos de aferição do ativismo judiciário decorre, em boa medida, da própria natureza do Direito Constitucional, onde a fusão do Direito e a Política impede que se encontre, sob um olhar excessivamente formalista e reducionista, respostas que atendam aos anseios dicotômicos do ativismo, haja vista que o mesmo tem a pretensão - ao menos implícita -, de traçar linhas demarcatórias entre o atuar legítimo e ilegítimo dos Tribunais, o que dificilmente será alcançado enquanto o Direito Constitucional apresentar a supracitada fusão e se expressar por meio de enunciados axiológicos abertos e flexíveis, passíveis de manipulação interpretativa. 
IV - afastando-se, pois, da adoção de um conceito rígido de ativismo judiciário, empregamos a expressão em nosso trabalho para designar uma concepção difusa de exercício ilegítimo do poder judicial, em que o juiz toma decisões com base em suas convicções e ideologias pessoais, em detrimento dos termos da lei e da Constituição.

V - a expressão jurisdição constitucional não encontra conceituação pacífica na doutrina nacional, mas, para os fins de nosso trabalho, adotaremos a associação entre jurisdição e competência realizada pela maioria da doutrina estadunidense e parte da brasileira, de modo a conceber a jurisdição constitucional como a competência atribuída positivamente ao órgão judiciário supremo de um país, designadamente, o Supremo Tribunal Federal brasileiro e a Suprema Corte estadunidense.

VI - em nosso estudo comparado, buscamos realizar uma abordagem multidisciplinar de jurisdição constitucional e ativismo judiciário, com especial apoio do Direito e das Ciências Políticas, de modo que a análise não ficasse restrita às perspectivas jurídicas de teor teórico-dogmático e pudessem revelar, na medida do possível, os substratos histórico, político, econômico e social da atuação do Supremo Tribunal Federal brasileiro e da Suprema Corte estadunidense.

VII - sob uma perspectiva histórica, as constantes rupturas políticas e constitucionais ocorridas no Brasil desde a sua Independência em 1822, não permitiram um amadurecimento sólido do Supremo Tribunal Federal e de seu locus de atuação junto aos demais Poderes e a sociedade, ao contrário dos Estados Unidos da América, onde a Suprema Corte se assenta em uma Constituição consideravelmente estável e pôde armazenar significativa carga de experiência histórica em seus mais de dois séculos de existência, ainda que presentes períodos de conflitos e incertezas.

VIII - a competência originária do Supremo Tribunal Federal é significativamente mais extensa do que a da Suprema Corte, obrigando-o a conhecer ações que, muitas vezes, carregam dentro de si temas polêmicos e de matiz político, como ocorreu, ad exemplum, com as ADPFs 132 e 178 (união homoafetiva), ADPF 54 (aborto de feto anencefálico) e ADI 4467 (obrigatoriedade ou não do porte de título de leitor no ato do voto. A Suprema Corte, por seu turno, tem competências originárias restritíssimas e ainda desenvolveu precedents que lhe permitem exercer juízo de admissibilidade discricionário sobre elas. 
IX - a competência recursal do STF e da Suprema Corte é expressivamente ampla e, em tese, permite que eles revertam qualquer decisão proferida nos Tribunais inferiores, desde que provocados. Todavia, enquanto a Suprema Corte realiza autocontenção de sua jurisdição, admitindo apenas de 1 a $\%$, em média, dos recursos a ela dirigidos via writ of certiorari, o Supremo Tribunal Federal tem um índice de reconhecimento de Repercussão Geral dos Recursos Extraordinário próximo de 70\% (setenta por cento).

X- o writ of certiorari, apesar de sua natureza discricionária, é um dos mecanismos mais importantes de autocontenção (self-restraint) da Suprema Corte, por várias razões: i) permite que a Corte se afaste de ações que contenham em seu bojo temas de matiz político, cujo julgamento certamente será polêmico e rotulado de ativista; ii) ao não admitir um caso, a decisão de segunda instância é mantida e valorizada, descentralizando o poder da palavra final da prestação jurisdicional, agora compartilhado entre a Suprema Corte e os demais Tribunais; iii) ao analisar poucas ações, a Corte pode julgar melhor e com maior celeridade.

XI - o controle de constitucionalidade e a judicial review tem ambientes de formação radicalmente distintos no Brasil e nos EUA. Enquanto o primeiro foi por nós importado e defendido, teoricamente, como uma função de garantia da Constituição por idealizados critérios puramente jurídicos e técnicos, a segunda teve o seu nascedouro nas disputas partidárias entre Federalistas e Republicanos, durante as eleições presidenciais de 1800, as quais resultaram no uso do Poder Judiciário como um bunker partidárioideológico federalista (episódio dos midnight judges), e culminou na decisão Marbury v. Madison. Este ambiente hostil e controverso de formação promoveu um sentido pragmático de judicial review em que direito e política andam de mãos dadas. No Brasil, este casamento não parece ser aceito de forma unânime, pois para significativa parte da comunidade jurídica e política, o STF deve ser um órgão apolítico e deve julgar de forma exclusivamente jurídica e técnica.

XII - o controle de constitucionalidade e a judicial review são o principal locus de manifestação do ativismo judicial, na medida em que as Constituições brasileira e estadunidense possuem cláusulas abertas e principiológicas que permitem a manipulação 
de seu sentido normativo, canalizando a expressão ideológica de seus intérpretes e julgadores.

XII - a Constituição e a legislação brasileira são responsáveis, em boa parcela, pelo elevadíssimo grau de liberdade de atuação que atualmente goza o Supremo Tribunal Federal, na medida em que elas positivaram inúmeras ações de fluidas hipóteses de cabimento (ADI, ADC, ADPF, RE, Reclamação, etc.), provendo-o, inclusive, com institutos altamente manipuláveis, como a modulação de efeitos e as sentenças aditivas, além de permitir sua atuação aos moldes legislativos por meio da súmula vinculante.

XIII - sob o prisma normativo, o Brasil e os Estados Unidos compartilham de um modelo próximo de preenchimento dos cargos de seus órgãos judiciários supremos, consubstanciado na indicação presidencial (observados alguns requisitos previstos na Constituição brasileira que não existem nos EUA), seguido de aprovação senatorial.

XIV - em relação ao processo de seleção dos membros do STF e da Suprema Corte, há considerável distinção entre os Estados Unidos e no Brasil, já que, dentre nós, a escolha está fortemente enraizada em um reinado quase absoluto do Executivo, enquanto que a escolha do justices da Suprema Corte envolve a participação ativa de inúmeros atores em âmbito nacional ou setorial, como: i) o Poder Executivo, que encomenda relatórios a seu Departamento de Justiça e ao White House Office of Legal Policy; ii) o FBI (Federal Bureau of Investigation), que averigua a vida pregressa dos candidatos; iii) a ABA (American Bar Association), que realiza estudos pormenorizados e entrevista os candidatos e pessoas próximas a ele, formulando um ranking; iv) os grupos de interesse, que não se furtam em apoiar ou descreditar candidatos de acordo com seu perfil ideológico, como a NAACP (National Association for the Advancement of Colored People); v) os partidos políticos, que pressionam por candidatos de sua inclinação ideológica e trazem consigo as aspirações dos grupos de interesse e dos parlamentares; vi) a extensa cobertura da mídia e a manifestação da opinião pública, que reconhecem a importância da Suprema Corte na vida política do país; e vii) atuação incisiva do Senado Federal.

XV - historicamente, o Senado estadunidense tem participado ativamente do processo de seleção, opinando e contestando as indicações presidenciais, sendo que, até o 
momento, uma em cada cinco indicações foi rejeitada e outras tantas foram retiradas antes mesmo da votação ser iniciada. Embora a aprovação ou desaprovação final, em boa medida, esteja associada a existência de uma maioria do governo naquela Casa, o fato é que o papel atuante do Senado conduziu a um necessário diálogo com o Executivo, impedindo que este escolhesse arbitrariamente e exercesse influência demasiada sobre os futuros membros da Suprema Corte. No Brasil, o Senado Federal desempenha um papel muito tímido, sendo que sua sabatina é utilizada mais para a familiarização dos parlamentares com o futuro Ministro do STF, do que para a perquirição da vida pregressa do indicado, seu perfil ideológico e suas aptidões técnicas para o cargo.

XVI - a despeito das enormes diferenças entre o processo de seleção nos Estados Unidos e no Brasil, não há razões para crer que, tanto em um quanto no outro, as escolhas sejam feitas de forma aleatória ou acriteriosa, de modo que há oportunidade de se analisar o perfil profissional e ideológico dos candidatos e, se desejável for, afastar aqueles de inclinação ativista.

XVII - tanto no Supremo Tribunal Federal quanto na Suprema Corte verificamos a existência da symbolic representation, por meio da qual são nomeados membros de diversas origens de gênero, etnias ou classes sociais, buscando-se uma maior legitimidade da Corte perante a sociedade.

XVIII - a agenda setting do Supremo Tribunal Federal é formada sem qualquer ordem ou prazo para julgamento, o que é agravado pela ausência de critérios para o pedido de vistas e desrespeito ao seu limite temporal, de modo que a pauta se torna obscura, ineficiente e injusta, ficando manipulável e vulnerável ao ativismo. Na Suprema Corte, por seu turno, toda ação admitida em determinado termo (ano judicial) é julgada até o seu final, salvo raras exceções. Na prática, isto que dizer que toda ação é julgada em 1 (um) ou, no máximo, 2 (dois) anos, e a pauta é preestabelecida para que todos os justices possam estudar previamente o processo $\overline{\bar{j}}$ e julgá-lo de forma conjunta e definitiva em apenas uma sessão (salvo as raras exceções), não havendo pedido de vistas.

IX - o modo de processamento e julgamento do Supremo Tribunal Federal confere excessiva autoridade individual ao julgador, que detém o poder de decidir monocrática ou liminarmente (impondo suas convicções e/ou contrariando as decisões de seus pares), e 
conformar a pauta de julgamento (não havendo critérios ou limites temporais para se apresentar um processo para julgamento ou pedir vistas). Tal modelo impulsiona consideravelmente o voluntarismo e, por consequência, o ativismo, já que não há uma atuação coletiva do órgão, mas um decisionismo individual de seus membros. A Suprema Corte, ao contrário, realiza os seus julgamentos de forma coletiva e com pauta prédefinida, mecanismos que diluem o personalismo e filtram a imposição de convicções pessoais.

$\mathrm{X}$ - o ativismo judicial pode ser limitado de diversas maneiras por elementos externos ao Poder Judiciário, em virtude, principalmente, da ausência de autoefetividade absoluta de todos os seus julgados, que muitas vezes exigem a participação de órgãos governamentais, do legislativo e da própria sociedade para a sua concretização (implementation process). Além do mais, há a possibilidade de reversão legislativa da decisão, colocando em confronto a interpretação judicial e o novo diploma promulgado, como ocorreu, no Brasil, nos casos da verticalização partidária e do número de cadeiras de vereadores nos Municípios. Por fim, há o simples desrespeito social, situação que o Judiciário pouco pode combater já que funciona apenas por provocação, e não detém função fiscalizadora e executória nos mesmos moldes que a Administração Pública.

XI - atualmente, o Supremo Tribunal Federal e a Suprema Corte vivem momentos históricos distintos. Enquanto que o primeiro está em uma fase de plena expansão jurisdicional e, por conseguinte, sofre incisivas críticas de atuação ativista, a segunda revela-se bem contida (self-restraint) após as inúmeras nomeações de justices conservadores pelo Partido Republicano, que deram fim às polêmicas atuações das Cortes de Warren e Burger. 


\section{BIBLIOGRAFIA}

ACKERMAN, Bruce. The failure of the founding fathers: Jefferson, Marshall and the rise of presidential democracy. Cambridge: Harvard University Press, 2005.

. The living constitution. Harvard Law Review, Cambridge, vol. 120, nº 7, pp. 1737-1812, maio de 2007.

. The new separation of powers. Harvard Law Review, Cambridge, vol. 113, nº 3, pp. 633-729, janeiro de 2000.

ALEXY, Robert. A theory of constitutional rights. Traduzido por Julian Rivers. Oxford University Press, 2002.

ALMEIDA, Fernanda Dias Menezes de. Competências na Constituição de 1988. $5^{\mathrm{a}}$ ed. São Paulo: Atlas, 2010.

. Conflitos entre entes federativos: atuação do Supremo Tribunal Federal no regime da Constituição de 1988. In: MORAES, Alexandre (coord.). Os 20 anos da Constituição da República Federativa do Brasil. São Paulo: Atlas, 2009.

AMARAL JUNIOR, José Levi Mello do (coord.). Estado de direito e ativismo judicial. São Paulo: Quartier Latin, 2010.

ARISTOTEles. A Política. Tradução de Roberto Leal Ferreira. São Paulo: Martins Fontes, 2000.

ARNAUD, André-Jean (direção) [et. al] Dicionário Enciclopédico de Teoria e de Sociologia do Direito. Tradução de Patrice Charles , F. X. Willaume. Rio de Janeiro: Renovar, 1999. 
BACHOFF, Otto. Normas constitucionais inconstitucionais?. Tradução de José Manuel M. Cardoso da Costa. Coimbra: Almedina, 1994.

BAGNOLI, Vicente; BARBOSA, Susana Mesquita; OLIVEIRA, Cristina Godoy. História do direito. Rio de Janeiro: Elsevier, 2009.

BARBOSA, Rui. Atos inconstitucionais. 1. ed. Campinas: Russel, 2003.

BARROSO, Luis Roberto. Interpretação e aplicação da Constituição: fundamentos de uma dogmática constitucional transformadora. $5^{\text {a }}$ ed. São Paulo: Saraiva, 2003.

O controle de constitucionalidade no direito brasileiro. $4^{\text {a }}$ ed. São Paulo: Saraiva, 2009.

BASILE, Juliano. Dilma escolha Rosa Weber, do TST, para o Supremo. Valor Econômico. Disponível em <http://www.valor.com.br/politica/1086370/dilma-escolherosa-weber-do-tst-para-o-supremo $>$. Acesso em 8.12.2011.

BAUM, Lawrence. The Supreme Court. 10ª ed. Washington, DC: CQ Press, 2010.

BERMAN, José Guilherme. Ativismo judicial, judicialização da política e democracia. Revista da Ajuris, Porto Alegre, v. 36. n. 116, p. 209-26, dez 2009.

BICKEL, Alexander M. The least dangerous branch: the Supreme Court at the bar of politics. $2^{\mathrm{a}}$ ed. New Haven: Yale University Press, 1986.

BOBBIO, Norberto. L'età dei diritti. Torino: Einaudi, 1997.

BONAVIDES, Paulo. Curso de direito constitucional. $13^{\mathrm{a}}$ ed. São Paulo: Malheiros Editores, 2003.

CAENEGEM, Raoul Charles Van. The birth of the english common law. $2^{\mathrm{a}}$ ed. Cambridge: Cambridge University Press, 1988. 
CAGGIANO, Monica Herman Salem. A emergência do Poder Judiciário como contraponto ao bloco monocolor Legislativo/Executivo. In: MORAES, Alexandre (coord.). Os 20 anos da Constituição da República Federativa do Brasil. São Paulo: Atlas, 2009.

Comportamento eleitoral. Centro de Estudos Políticos e Sociais. Barueri, São Paulo, 2010.

Direito parlamentar e direito eleitoral. $1^{\mathrm{a}}$ ed. São Paulo: Manole, 2004.

- O controle da omissão legislativa e administrativa. Disponível em: $<$ http://www.mackenzie.br/fileadmin/Graduacao/FDir/Artigos/artigos_2009/monica.pdf $>$. Acesso em $1^{\circ}$ de dezembro de 2010.

Oposição na política: propostas para uma rearquitetura da democracia. São Paulo: Angelotti, 1995.

. Sistemas eleitorais $\mathbf{x}$ representação política. Brasília: Ed. Senado Federal, 1990.

CALABRESI, Steven G. (edit.). Originalism: a quarter-century of debate. Washington, DC: Regnery Publishing, 2007.

CANOtilho, J. J. Gomes. Direito constitucional e teoria da Constituição. $7^{\mathrm{a}}$ ed. Almedina.

CAPPELLETTI, Mauro. Juízes legisladores? Tradução de Carlos Alberto Alvaro de Oliveira. Porto Alegre: Sergio Antonio Fabris Editor, 1999.

O controle judicial de constitucionalidade das leis no direito comparado. $2^{\mathrm{a}}$ ed. Porto Alegre: Sergio Antonio Fabris, 1999.

CHEMERINSKY, Erwin. Constitutional law: principles and policies. 3 ed. New York: Aspen, 2006. 
COSTA, Raimundo. Fux entra na lista de padrinhos que disputam indicação ao STF. Valor Econômico. Disponível em <http://www.valor.com.br/politica/1040820/fux-entrana-lista-de-padrinhos-que-disputam-indicacao-ao-stf>. Acesso em 8.12.2011.

CRETELLA NETO, José. Dicionário de processo civil. 2. ed. Rio de Janeiro: Forense, 2002.

DAHL, Robert. Democracy and its critics. Yale University Press, 1989.

On democracy. Yale University Press, 1998.

Decision making in a democracy: the Supreme Court as a national policy maker. Journal of public Law n. 6, pp 279-295, 1957.

DALLARI, Dalmo de Abreu. O poder dos juízes. $3^{\text {a }}$ ed. São Paulo: Saraiva, 2008.

DANTAS, David Diniz. Interpretação constitucional no pós-positivismo: teoria e casos práticos. São Paulo: Madras, 2004.

DANTAS, Luis Rodolfo Ararigboia de Souza. Hermenêutica constitucional e transponibilidade das cláusulas pétreas. In: BOUCAULT, Carlos Eduardo de Abreu; RODRIGUEZ, Jose Rodrigo (orgs.). Hermenêutica Plural: possibilidades jusfilosoficas em contextos imperfeitos. São Paulo: Martins Fontes, 2002.

Limites materiais ao poder de reforma constitucional. Mestrado apresentado à Faculdade de Direito da Universidade de São Paulo para obtenção do título de Mestre em Direito do Estado. São Paulo, 2002.

DAVID, René. Os grandes sistemas do direito contemporâneo. São Paulo: Martins Fontes, 1998.

DIMOULIS, DIMITRI (coord.). Dicionário brasileiro de direito constitucional. Instituto Brasileiro de Direito Constitucional. São Paulo: Saraiva, 2007. 
DINAMARCO, Cândido Rangel. Instituições de direito processual civil. Vol. I. 6. ed. Rev. e atual. São Paulo: Malheiros, 2009.

DINIZ, Maria Helena. Dicionário jurídico. $3^{\mathrm{a}}$ ed. rev. at. e aum. São Paulo: Saraiva, 2008.

DWORKIN, Ronald. Law's empire. Sine loco: The Belknap Press of Harvard University Press, 1986.

O direito da liberdade: a leitura moral da Constituição norte-americana. Tradução de Marcelo Brandão Cipolla. São Paulo: Martins Fontes, 2006.

ELY, John Hart. Democracy and distrust. Cambridge, Massachusetts: Harvard University Press, 1980.

FAIRGRIEVE, Duncan; WATT, Horatia Muir. Common law et tradition civiliste. 1. ed. Paris: Presses Universitaire de France, 2006.

FERRATER MORA, José. Dicionário de Filosofia. Texto preparado por Eduardo Garcia Belsunce e Ezequiel de Olasco. Tradução por António José Massano e Manuel J. Palmeirim. $4^{\mathrm{a}}$ ed. Lisboa, Publicações Dom Quixote. 1978.

FERREIRA, Aurélio Buarque de Holanda. Novo dicionário da língua portuguesa. $1^{\mathrm{a}} \mathrm{ed}$. rev. e aum. Rio de Janeiro: Editora Nova Fronteira, 1975.

FERREIRA FILHO, Manoel Gonçalves. A democracia possível. $2^{\mathrm{a}}$ ed. São Paulo: Saraiva, 1974.

Aspectos do Direito Constitucional contemporâneo. $2^{\mathrm{a}}$ ed. São Paulo: Saraiva, 2009.

Curso de direito constitucional. $33^{\mathrm{a}}$ ed. São Paulo: Saraiva, 2007. 
- O Poder Judiciário na Constituição de 1988: judicialização da política e politização da justiça. Revista Jurídica da Procuradoria Geral do Município de São Paulo, São Paulo, n.1, p.21-42, 1995.

FIELD, Richard E.; KAPLAN, Richard; CLERMONT, Kevin M. Materials for a basic course in civil procedure. 7. ed. Westbury, New York: The Foundation Press, 1985.

FRIEDENTHAL, Jack H.; KANE, Mary Kay; MILLER, Arthur R. Civil procedure. Saint Paul, Minnesota: Publishing Co., 1985.

GADAMER, Hans-Georg. Verdade e Método I: traços fundamentais de uma hermenêutica filosófica. Tradução de Flavio Paulo Meurer. $6^{\mathrm{a}}$ ed. Petrópolis, RJ: Editora Vozes, Bragança Paulista, SP: Editora Universitária São Francisco, 1997.

GALUCCI, Mariângela. Com nova ministra, direitos sociais ganham força na corte. $\mathbf{O}$ Estado de São Paulo. Disponível em <http://www.estadao.com.br/noticias/impresso,comnova-ministra-direitos--sociais-ganham-forca-na-corte--,796879,0.htm? $\mathrm{p}=1>$. Acesso em 8.12 .11

GRECO FILHO, Vicente. Direito processual civil brasileiro. Vol. 2. (atos processuais a recursos e processos nos tribunais). 20 ed rev. e atual. São Paulo: Saraiva, 2009.

HABERLE, Peter. Hermenêutica constitucional: a sociedade aberta dos intérpretes da constituição: contribuição para a interpretação pluralista e "procedimental" da constituição. Tradução Gilmar Ferreira Mendes. Porto Alegre: Sergio Antonio Fabris Editor, 2002.

HAMILTON, Alexander; MADISON, James; JAY, John. The federalists papers. Signet Classics, 2003.

HESSE, Konrad. A força normativa da Constituição. Tradução de Gilmar Ferreira Mendes. Porto Alegre: Sérgio Antonio Fabris Editor, 1991. 
HOUAISS, Antônio [et al]. Dicionário Houaiss da língua portuguesa. Elaborado pelo Instituto Antônio Houaiss de Lexicografia e Banco de Dados da Língua Portuguesa. Rio de Janeiro: Objetiva, 2009.

LASSALE, Ferdinand. A essência da Constituiçãa. $6^{\text {a }}$ ed. Rio de Janeiro: Editora Lumen Juris, 2001.

LEWIS, Frederick P. The context of judicial activism: the endurance of the Warren Court legacy in a conservative age. Sine loco: Rowman \& Littlefield Publishers, 1999.

LOCKE, John. Two treatises of government and a letter concerning toleration. Binghamton: Yale University Press, 2003.

KANTOROWICZ, Hermann U. La lotta per la scienza del diritto. Traduzido por Raffaele Majetti. Milão: Remo Sandron Editore, 1908.

KELSEN, Hans. Jurisdição constitucional. 2a ed. São Paulo: Martins Fontes, 2007.

LEAL, Roger Stiefelmann. A judicialização da política. Revista dos Tribunais. Cadernos de Direito Constitucional e Ciência Política, São Paulo, v. 29, p. 230-237, 1999.

Pluralismo, políticas públicas e a Constituição de 1988. In: MORAES, Alexandre (coord.). Os 20 anos da Constituição da República Federativa do Brasil. São Paulo: Atlas, 2009.

LEMBO, Claudio. A pessoa: seus direitos. Barueri: Manole, 2007.

Visões do Cotiano. Série Culturalismo Jurídico. Barueri: Manoel, 2012.

LOEWENSTEIN, Carl. Teoria de la Constitucion. Barcelon: Ariel, 1970.

MARMELSTEIN, George. O Ativismo judicial na perspectiva da filosofia moral. In: OLIVEIRA, Umberto Machado de (coord.). Ativismo Judicial. Curitiba: Juruá Editora, 2010. 
MARQUES, José Frederico. Instituições de direito processual civil. 1. ed. atual. Campinas: Millennium, 1999.

MAXIMILIANO, Carlos. Hermenêutica e aplicação do direito. $8^{\mathrm{a}}$ ed. São Paulo: Livraria Freitas Bastos, 1965.

MAZOTTI, Marcelo. As escolas hermenêuticas e os métodos de interpretação das leis. Barueri: Minha Editora, 2010.

McCLOSKEY, Robert G. The american Supreme Court. Revised by Sanford Levinson. $5^{\text {a }}$ ed. Chicago, The University of Chigago Press, 2010.

MELlO FILHO, José Celso de. Notas sobre o Supremo Tribunal (Império e República). $2^{\text {a }}$ ed. Brasília: Supremo Tribunal Federal, 2007. Disponível em < http://www.stf.jus.br/arquivo/cms/sobreStfConhecaStfCuriosidadeStf/anexo/NotasInforma tivasEletronica161007.pdf>. Acesso em 30.11.2011.

MENDES, Gilmar Ferreira; COELHO, Inocencio Martires e BRANCO, Paulo Gustavo Gonet. Curso de direito constitucional. $4^{\text {a }}$ ed. São Paulo: Saraiva, 2009.

MENDES, Gilmar Ferreira. Jurisdição constitucional: o controle abstrato de normas no Brasil e na Alemanha. São Paulo: Saraiva, 1996.

MIRANDA, Jorge. Manual de direito constitucional. Tomo II. $5^{\mathrm{a}}$ ed. Coimbra: Coimbra Editora. 2003

MONTESQUIEU, Charles-Louis de Secondatt, barão de la Brède e de. De l'esprit des loi. vol I. Mesnil-sur-1'Estrée, França: Gallimard, 1995.

MORAES, Alexandre de. Direito constitucional. 22a ed. São Paulo: Atlas, 2007. Jurisdição constitucional e tribunais constitucionais: garantia suprema da Constituição. São Paulo: Atlas, 2000. 
. (coord.). Os 20 anos da Constituição da República Federativa do Brasil. São Paulo: Atlas, 2009.

. Legitimidade da justiça constitucional. In: MARTINS, Ives Gandra da Silva (coord.). As vertentes do direito constitucional contemporâneo. Rio de Janeiro: América Jurídica, 2002.

MOREIRA, Vital. Princípio da maioria e princípio da constitucionalidade: legitimidade e limites da justiça constitucional. In: (vários autores), Legitimidade e legitimação da justiça constitucional. Coimbra: Coimbra editora. 1995.

O'BRIEN, David M. Constitutional law and politics. vol. 2. $6^{\text {a }}$ ed. New York: W.W. Norton \& Company, 2005.

PFANDER, James E. Principles of federal jurisdiction. 2. ed. Sine loco: West, 2011.

PIÇARRA, Nuno. A separação dos poderes como doutrina e princípio constitucional: um contributo para o estudo das suas origens e evolução. Coimbra: Coimbra Editora, 1989.

POGREBINSCHI, Thamy. Ativismo judicial e direito: considerações sobre o debate contemporâneo. Direito, Estado e Sociedade, Rio de Janeiro, n. 17, p. 121-143, ago/dez 2000 .

QUIRK, William J.; BRIDWELL, R. Randall. Judicial dictatorship. Sine loco: Transaction Publishers, 1995

RAMOS, Elival da Silva. Ativismo judicial: parâmetros dogmáticos. São Paulo: Saraiva, 2010.

Controle de constitucionalidade no brasil: perspectivas de evolução. São Paulo: Saraiva, 2010 
RANIERI, Nina Beatriz Stocco; RIGHETTI, Sabine (orgs.). Direito à educação. São Paulo: Edusp, 2009.

ROOSEVELT III, Kermit. The myth of judicial activism: making sense of Supreme Court decisions. Yale University Press. 2006.

RUSSO, Charles J. Judges as umpires or rule makers? The role of the judiciary in educational decision making in the United States. In Education Law Journal, 2009.

SCALIA, Antonin. Originalism: the lesser evil. The University of Cicinnati Law Review, vol 57, pp. 849-865, 1989.

SCHMITT, CARL. O guardião da constituição. Tradução de Geraldo de Carvalho. Belo Horitzonte: Del Rey, 2007.

SCHWARTZ, Bernard. A history of the Supreme Court. Sine loco, Oxford University Press, 1993.

SIDOU, J.M. Othon. Dicionário jurídico. Academia brasileira de letras jurídicas. 4. ed. Rio de Janeiro: Forense Universitária, 1997.

SILVA, José Afonso da. Aplicabilidade das normas constitucionais. $6^{\text {a }}$ ed. São Paulo: Malheiros, 2003.

_. Curso de direito constitucional. 19a ed. São Paulo: Malheiros Editores, 2001.

Poder constituinte e poder popular. $1^{\mathrm{a}}$ ed. $2^{\mathrm{a}}$ tir. São Paulo: Malheiros, 2002.

SILVA, Luis Virgilio Afonso da. Direitos fundamentais: conteúdo essencial, restrições e eficácia. $2^{\mathrm{a}}$ ed. São Paulo: Malheiros, 2010.

__ Taking from the poor to give to the rich: the individualistic enforcement of social rights. 
$<$ http://www.enelsyn.gr/papers/w13/Paper\%20by\%20Prof.\%20Virgilio\%20Afonso\%20da \%20Silva.pdf>. Acesso em 10.11.2011.

SOARES, Guido Fernando Silva. Common Law: introdução ao direito dos EUA. $2^{\mathrm{a}}$ ed. São Paulo: Editora Revista dos Tribunais, 2000.

TATE, C. Neal; VALLINDER, Tobjörn. The global expansion of judicial power. New York: New York Press, 1995.

TAVARES, André Ramos (coord.). Teoria da justiça constitucional. São Paulo: Saraiva, 2005 .

. Tribunal e jurisdição constitucional. São Paulo: Celso Bastos Editor, 1998.

The oxford english dictionary. Vol. I. 2a ed. Oxford: Clarendon Press, 2000.

TRIBE, Laurence H. American Constitutional Law. vol. 1. 3.ed. Nova Iorque, Nova Iorque: Foundation Press, 2000.

URBINATI, Nadia. Representative democracy: principles and genealogy. The University of Chicago Press, 2006.

VALLE, Vanice Regina Lírio do (org.). Ativismo jurisdicional e o Supremo Tribunal Federal. Curitiba: Juruá, 2009.

VERÍSSIMO. Marcos Paulo. A judicialização dos conflitos de justiça distributiva no Brasil: o processo judicial no pós-1988. Doutorado apresentado à Faculdade de Direito da Universidade de São Paulo para obtenção do título de Doutor em Direito Processual. São Paulo, 2006.

VITOVSKY, Vladimir Santos. Activismo judicial: só pecados e virtudes? Contribuições para uma teoria sociojurídica. In: OLIVEIRA, Umberto Machado de (coord.). Ativismo Judicial. Curitiba: Juruá Editora, 2010. 
YOGIS, John A. Canadian Law Dictionary. $5^{\mathrm{a}}$ ed. Sine loco: Barron's, 2003.

WARAT, Luis Alberto. Introdução Geral ao Direito. Porto Alegre: Sergio Antonio Fabris Edito, 1994.

WOLFE, Christopher. Judicial activism: bulwark of freedom or precarious security?. Rev. ed. Rowman \& Littlefield Publishers, 1997. 